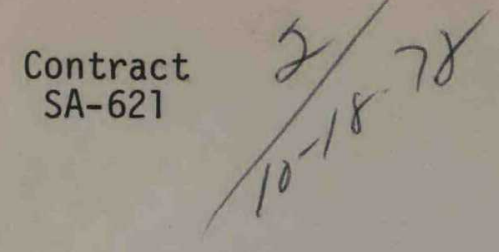

\title{
MASTER MASTER
}

RHO-BWI-C-2

HIGH-LEVEL WASTE-BASALT INTERACTIONS

ANNUAL PROGRESS REPORT

FOR THE PERIOD

FEBRUARY 1, 1977 TO SEPTEMBER 30, 1977

Gregory J. McCarthy

Barry E. Scheetz

May 1978

Prepared for Rockwell Hanford Operations, A Prime Contractor to U. S. Department of Energy, Under Contract Number EY-77-C-06-1030

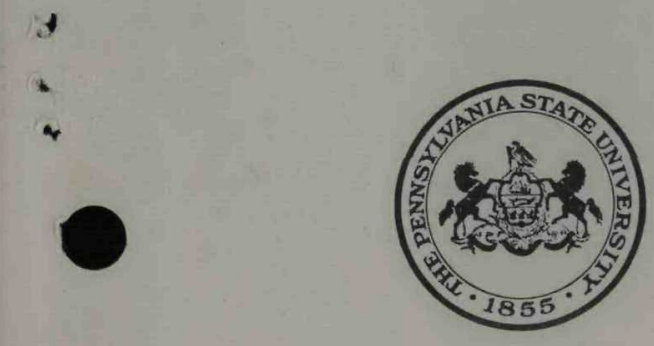

\section{MATERIALS RESEARCH LABORATORY}

\author{
THE PENNSYLVANIA STATE UNIVERSITY
}

UNIVERSITY PARK, PENNSYLVANIA 16802 


\section{DISCLAIMER}

This report was prepared as an account of work sponsored by an agency of the United States Government. Neither the United States Government nor any agency Thereof, nor any of their employees, makes any warranty, express or implied, or assumes any legal liability or responsibility for the accuracy, completeness, or usefulness of any information, apparatus, product, or process disclosed, or represents that its use would not infringe privately owned rights. Reference herein to any specific commercial product, process, or service by trade name, trademark, manufacturer, or otherwise does not necessarily constitute or imply its endorsement, recommendation, or favoring by the United States Government or any agency thereof. The views and opinions of authors expressed herein do not necessarily state or reflect those of the United States Government or any agency thereof. 


\section{DISCLAIMER}

Portions of this document may be illegible in electronic image products. Images are produced from the best available original document. 
This report was prepared as an account of work sponsored by the United States Government.

Neither the United States, nor the United States Department of Energy, nor any of their employees, nor any of their contractors, subcontractors, or their employees, makes any warranty, express or implied, or assumes any legal liability or responsibility for the accuracy, completeness, or usefulness of any information, apparatus, product or process disclosed, or represents that its use would not infringe privately owned rights. 
HIGH-LEVEL WASTE-BASALT INTERACTIONS

ANNUAL PROGRESS REPORT

FOR THE PERIOD

FEBRUARY 1, 1977 TO SEPTEMBER 30, 1977

\author{
Gregory J. McCarthy \\ Barry E. Scheetz
}

May 1978

Prepared for Rockwell Hanford Operations, A Prime Contractor to U. S. Department of Energy, Under Contract Number EY-77-C-06-1030

This report was prepared as an account of work sponsored by the United States Government. Neither the United States, nor the United States Department of Energy, nor any of their employees, nor any of their contractors, subcontractors, or their employees, makes any warranty, express or implied, or assumes any legal liability or responsibility for the accuracy, completeness, or usefulness of any information, apparatus, product or process disclosed, or represents that its use would not infringe privately owned rights.

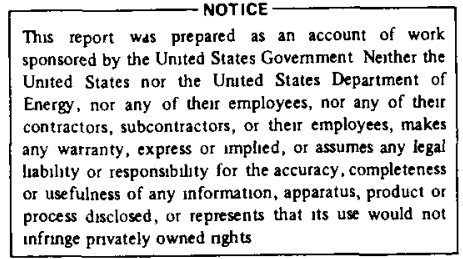

Materials Research Laboratory

The Pennsylvania State University University Park, Pennsylvania 16802 
TABLE OF CONTENTS

1.0 Summary

Page

2.0 Introduction

3.0 Nuclear Waste Forms

3.1 Introduction

3.1.1 Thermodynamic Stability and Structural State

3.1.2 Chemical Composition

3.1.3 History of Waste Form: Decay Heat Output 18

3.1.4 Leachability

3.1.5 Other Characteristics

3.2 Waste Form Characteristics 20

3.2.1 Spent Unreprocessed Fuel 20

$\begin{array}{ll}3.2 .2 \text { Calcine } & 21\end{array}$

3.2.3 Glass 24

3.2.4 Supercalcine 26

4.0 Basalts 32

4.1 Columbia River/Hanford Basalts 32

4.1.1 BCR-1 32

4.1.2 Hanford Basalts 32

4.2 Pressure-Temperature Effects on Basalts 34

5.0 Experimental Equipment and Procedures 38

5.1 Dry-Low Pressure Experiments (Type A) 38

5.2 Hydrothermal Experiments (Types $C$ and D) 39

5.2.1 Equipment and Facilities 39

5.2.2 Experimental Procedures 45

5.3 Characterization 49

5.3.1 Optical Microscopy 49

5.3.2 X-Ray Powder Diffraction $\quad 50$

5.3.3 Scanning Electron Microscopy 50

6.0 Preliminary Results and Discussion of the
Reconnaissance Experiments

6.1 Dry-Low Pressure Experiments (Type A) 52

6.2 Hydrothermal Experiments (Types $C$ and D) 56

6.2.1 Hydrothermal Treatment of Waste Forms 58

6.2.2 Hydrothermal Treatment of Basalts 65

6.2.3 Hydrothermal Treatment of Waste-Basalt Mixtures 68

Appendix A - Hanford Ground Water Formulation $\quad 79$

Appendix B - Run Tables for Reconnaissance Types A, C, and
D Experiments

Bibliography $\quad 11$

$\begin{array}{ll}\text { Distribution } & 113\end{array}$ 


\section{LIST OF ABBREVIATIONS}

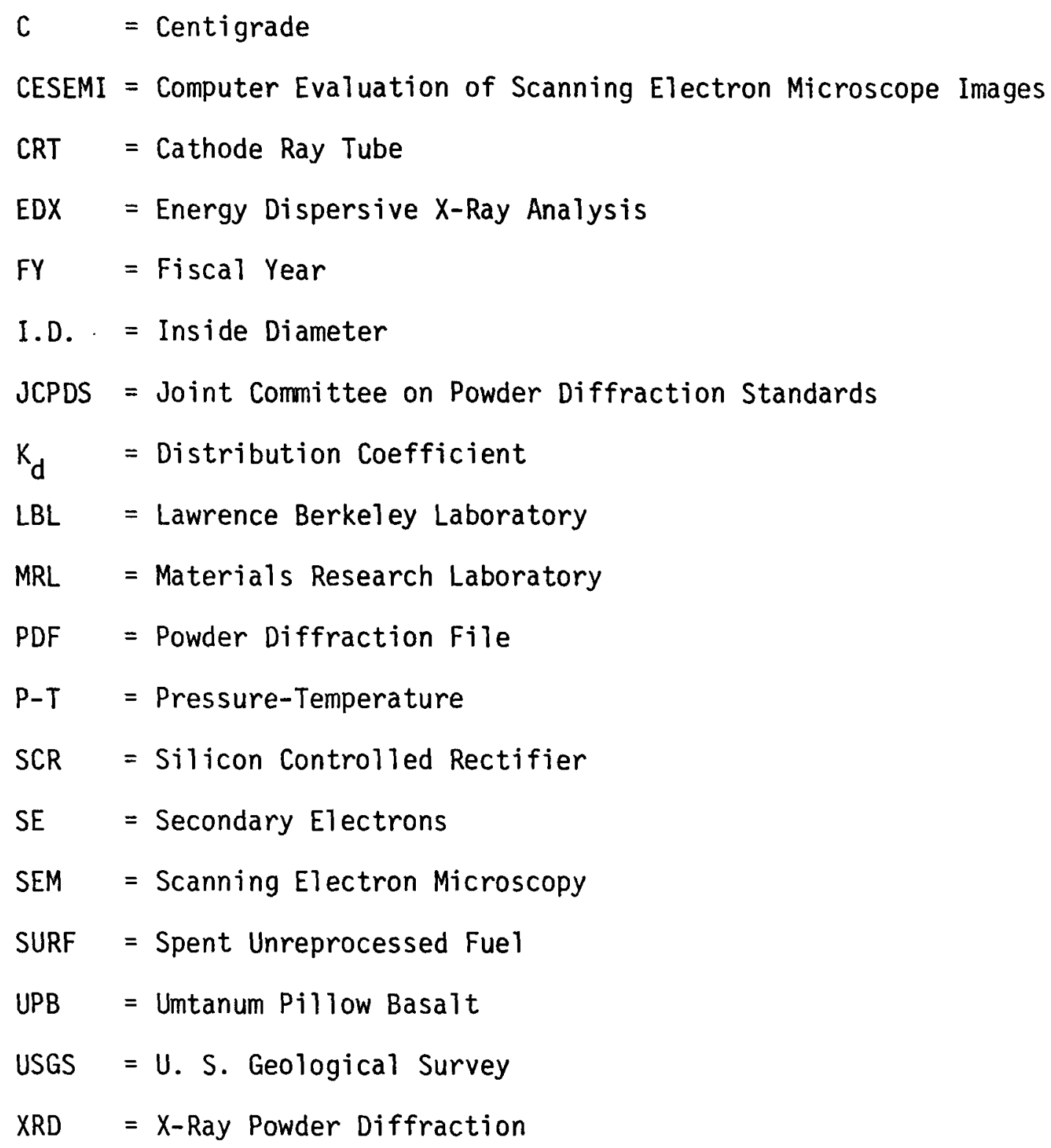




\subsection{Summary}

Commercial radioactive waste can be placed under ground in a basalt repository to contain significant amounts of radioactive decay heat for the first hundred or so years, which constitutes the "thermal period" of waste isolation, if the feasibility is determined that a basalt geology is a suitable medium for storage of radioactive wastes. Several physical-chemical changes analogous to natural geochemical processes can occur in and around this repository during the thermal period. The waste canister can act as a heat source and cause changes in the mineralogy and properties of the surrounding basalts. Geochemically, this is "contact metamorphism." This phenomenon needs to be investigated, because it could affect the behavior of the basalt with regard to migration of long-lived radionuclides away from the imnediate repository. The most credible scenario for rapid mobilization of the radionuclides contained in the waste form is intrusion of ground water into the repository. If this occurs during the thermal period, then the combination of heat and pressure would create a "hydrothermal" environment that could accelerate corrosion and breaching of the canister and subsequent interactions of the hydrothermal solutions, the waste, the repository rock, the remains of the canister, and any engineered containment structures. It is well known that even the relatively low-grade hydrothermal conditions possible in the repository (temperatures up to 400 degrees Centigrade; pressures up to 300 bars) can cause extensive modifications in rocks and minerals. At the end of the thermal period, the residue of the original waste plus the waste-basalt interaction products would constitute the actual waste form (or "source term") subject to the low-temperature leaching and migration processes under investigation in other laboratories. It is quite possible and even likely that, for certain radionuclides, these interaction product waste forms would have superior fixation properties compared to the original radioactive waste.

During the last eight months of fiscal year 1977, a program was initiated at The Pennsylvania State University which had as its objective the determination of the nature and implication of any chemical or mineralogical changes in, or interactions between, each candidate radioactive waste form and representative Columbia River Basalt under the 
various relevant repository conditions during the thermal period. No waste-basalt interaction studies of this type had ever been done before, so it was expected that the major contribution from these eight months would be the mobilizing of the existina hydrothermal facilities and expertise for, and developing the approach and methodology to, such studies. The availability during the last five months of parallel support from the National Haste Terminal Storage Program for waste-shale interaction studies increased synergistically the personnel and facilities commitment to establishing many of these generic aspects of waste-basalt interaction studies. The convening of a waste-rock interactions conference at The Pennsylvania State University in July 1977 was also helpful in this respect. This, in turn, allowed us to focus most of their effort over the last two to three months of performing, and making substantial progress on interpreting, a significant number of waste-basalt interaction experiments.

Three sets of experimental parameters designed to represent three potential repository conditions were utilized.

- Dry repository - low pressure. The waste repository is open and in a retrievable mode of operation, so there is little or no pressure from the overburden. Specimens of waste, basalt, and waste + rock + canister are contained in sealed silica ampules and heated in a crucible furnace. Natural oxygen and water fugacity are maintained by including a large excess of the appropriate rock type in the sealed ampul.

- Dry sealed repository. The waste repository nas been backfilled and sealed. The pressure in the repository will range from 250 to 300 bars due to overburden. The water content will be that which is typically found under ground ( 2 to 8 weight percent). Specimens are contained in welded gold capsules. They are treated at the appropriate pressure and temperature in autoclaves or coldseal pressure vessels.

- Wet sealed repository. After a given period of time, the repository could conceivably fill with water. At that time, the system will contain abundant water and also experience elevated temperatures 
due to decay heat from the radioactive waste. The experiments performed under these conditions will utilize the same procedures as the "dry sealed repository."

Work on a matrix of 14 test specimens ( 2 basalts, 4 simulated waste forms, and mixtures of the waste forms and the basalts) to be evaluated as a function of temperature and pressure was initiated. A stainless steel powder was added to 2 of the mixed specimens to explore the effects of the canister on any observed interactions. The 4 simulated wastes were.

- "Spent fuel." This material is largely $\mathrm{UO}_{2}$ with some fission products.

- "Calcine." The unconsolidated powder made by drying and calcining liquid wastes at 600 to 800 degrees Centigrade. A Barnwell composition is being used (U. S. Department of Energy's PW-7a).

- "Glass." A monolithic borosilicate vitreous waste form - BattelleNorthwest's Code 76-68 is the specific formulation. Specimen was supplied by Battelle-ilorthwest. It is the same glass being used in the Office of Waste Isolation/Battelle-forthwest/Waste Isolation Safety Assessment Program.

- "Supercalcine." A crystalline ceramic waste form developed at The Pennsylvania State University and Battelle-ivorthwest. Formulation SPC-2 was prepared at Battelle-iNorthwest and processed at The Pennsylvania State University.

The two basalt specimens supplied by Rockwell Hanford Operations were: (1) Umtanum from Core Hole DDH-3; and (2) U. S. Geological Survey Standard Columbia River Basalt Sample BCR-1.

Altogether, 128 runs (waste, basalt, waste + basalt, and glass + basalt + stainless steel) were performed using the 3 repository conditions listed above at temperatures ranging from 200 to 400 degrees Centigrade. In addition, two 600-degree Centigrade dry-10w pressure sets of runs were also completed. Each run was examined briefly by optical microscopy and $x$-ray powder diffraction and the observations were compared to those for the original, untreated specimens. Those specimens in which obvious interactions could be observed by optical microscopy were also given 
preliminary characterization for microstructure and microchemistry by scanning electron microscopy/energy dispersive $X$-ray analysis. The following are highlights of the results obtained to date.

- So far, no substantial changes in basalt mineralogy have been noted when the basalts were treated alone in either the dry-low pressure or the hydrothermal experiments. More detailed characterization is needed, however, before a definite behavior trend can be derived.

- When either calcine alone or glass alone were brought in contact for several weeks with simulated Hanford ground water* under hydrothermal conditions (200 tn 400 degrees Centigrade; 300 to 400 bars), extensive interactions resulted. Much of the bulk of these wastes was dissolved by the fluid and re-precipitated as a suite of minerals or mineral-1ike phases. Figure 1.1 shows a specimen of waste glass 76-68 after a 400-degree Centigrade hydrothermal treatment. The appearance of quartz $\left(\mathrm{SiO}_{2}\right)$ and the needle-like zinc silicate phase suggests major breakdown of the glass structure followed by crystal growth of these and several other phases. This experiment will be repeated at several temperatures in the coming months with the object of determining the distribution coefficients $\left(K_{d}\right)$ of specific ions between the solutions and the crystalline phases.

- Supercalcine and spent unreprocessed fuel have shown little or no change in "bulk" phase assemblage when treated hydrothermally with either distilled water or Hanford ground water.

- In a somewhat surprising result, intimate mixtures of powdered calcine or glass with the basalts did show signs of the beginnings of interactions during the "dry-low pressure" experiments after as little as 4 weeks of treatment at 400 to 600 degrees Centigrade. Not much significance is attached to this result at this time, because of the accelerated mode of the experiment; namely, using mixed powders instead of essentially monolithic specimens of waste and basalt in contact across only a small area and the

*See Appendix A. 


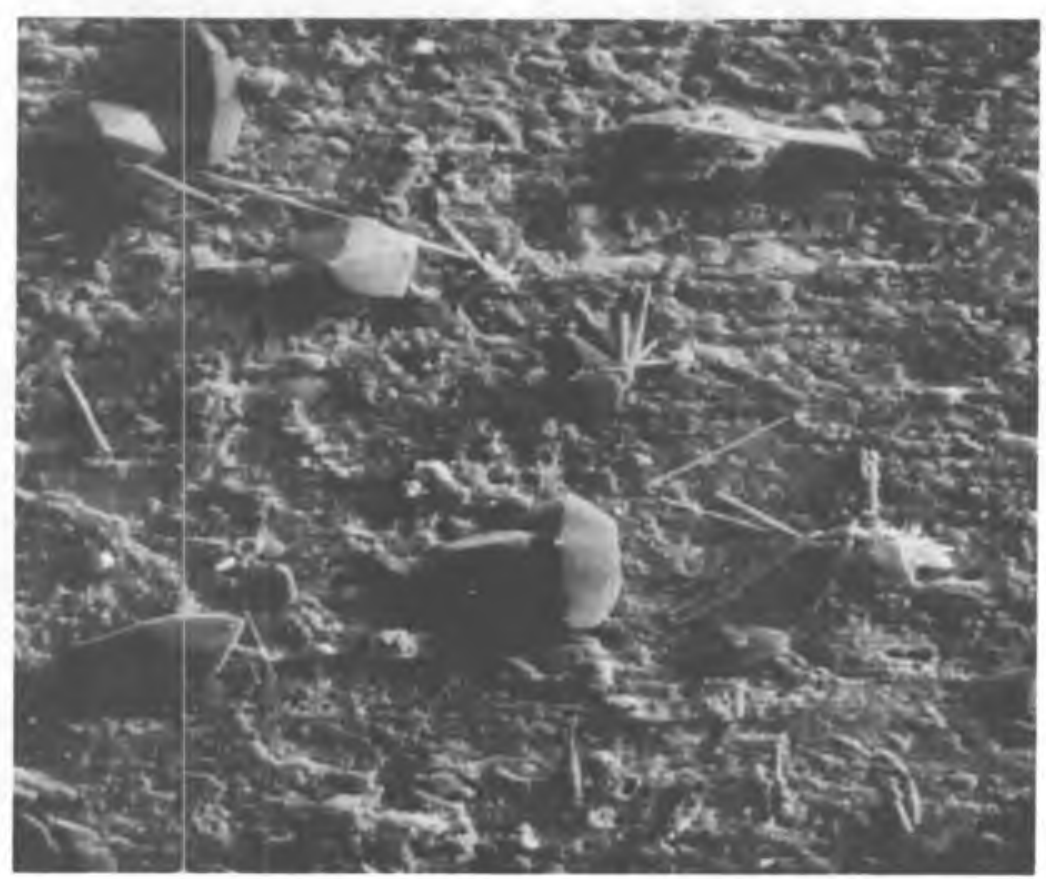

FIG. 1.1 Hydrothermal treatment of glass $76-68$ at 400 degrees Centigrade gives this product. The large $(-80 \mu \mathrm{m})$ crystals are quartz and the needles are a zinc silicate, probably willemite, $\mathrm{Zn}_{2} \mathrm{SiO}_{4}$

possibility of enhanced vapor transport due to the presence of a partial vacuum drawn upon the sample container to facilitate the experiment.

- Although basalt remained largely unaltered in all of the 30-day hydrothermal experiments, when it was present with calcine, substantial interactions occurred. For example, an aluminosilicate of $C s$ and $\mathrm{Na}$ has been observed to form in both 200- and 400-degree Centigrade hydrothermal treatments of calcine $+\mathrm{BCR}-1$ and calcine $+\mathrm{DDH}-3$ mixtures. The Cs comes from the calcine, the $\mathrm{Na}$ can come from the calcine, ground water, or basalt, but the $A 7+S i$ must come from the basalt, because neither occurs in calcine. The well-developed crystal morphology observed by scanning electron microscopy and several reflections in the $X$-ray diffractograms are consistent with an assignment of this phase to the pollucite-analcime solid solution series $\left[(\mathrm{Cs}, \mathrm{Na}) \mathrm{AlSi}_{2} \mathrm{O}_{6} \cdot \mathrm{nH}_{4} \mathrm{O}\right]$ (see Fig. 1.2). 


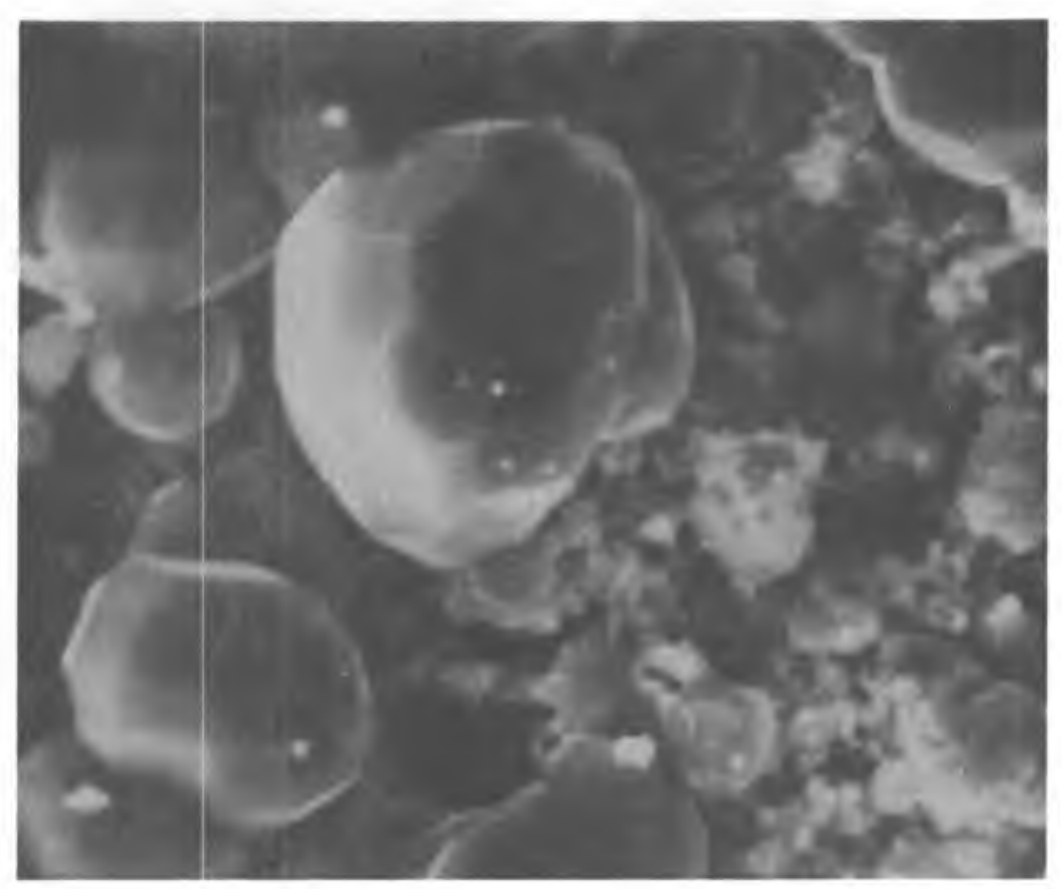

FIG. 1.2 Crystals of a Cs-Na aluminosilicate resulting from calcine/ basalt interactions under hydrothermal conditions at 200 to 400 degrees Centigrade; tentative phase identification $\mathrm{Na}-$ pollucite, ( $\mathrm{Cs}, \mathrm{Na}) \mathrm{AlSi}_{2} \mathrm{O}_{6} \cdot \mathrm{nH}_{2} \mathrm{O}$.

- The extensive hydrothermal alteration of glass 76-68 was observed also in those runs containing both glass and basalt. Figure 1.3 shows clusters of an alkali uranium silicate formed by hydrothermal treatment of glass $76-68$ in the presence of BCR-1 basalt at $400^{\circ} \mathrm{C}$. The yellow color of these needle crystals suggests that the uranium is present as a hexavalent uranyl complex.

- Scanning electron microscopy/energy dispersive X-ray analysis has been used to identify the chemistry of other crystalline phases which occur in many calcine/basalt or glass/basalt hydrothermal runs. 


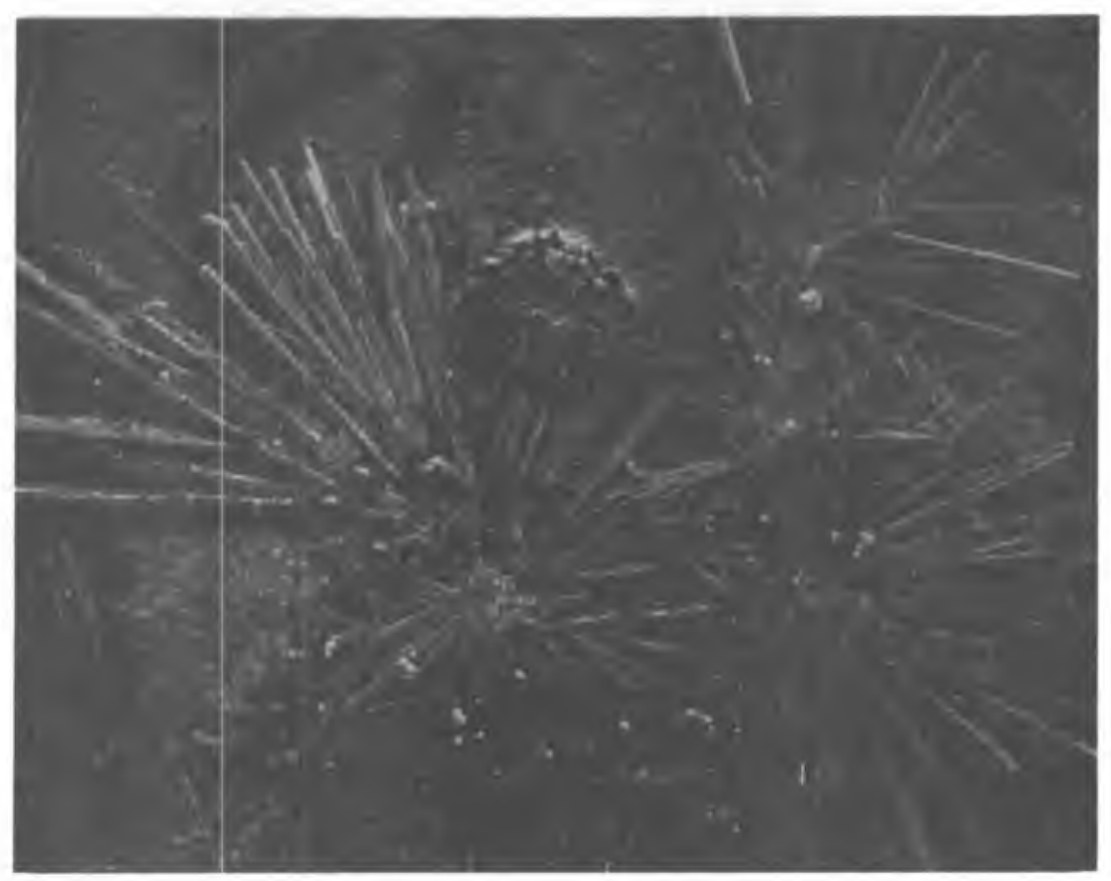

FIG 1.3 These 50-200 um needle-like crystals are an alkali uranium silicate formed during treatment of glass 76-68 in the presence of basalt BCR-1 at 400 degrees Centigrade, 400 bars for 2 weeks.

Chemistry

$\mathrm{Ca}, \mathrm{Sr}, \mathrm{Ba}, \mathrm{Mo}$

$\mathrm{Na}, \mathrm{Al}, \mathrm{Si}, \mathrm{Mo}$,

Minor $\mathrm{Ca}, \mathrm{K}, \mathrm{Fe}$

$\mathrm{Na}, \mathrm{Si}, \mathrm{Fe}$, Minor $\mathrm{K}, \mathrm{Ca}$

$\mathrm{Na}, \mathrm{Al}, \mathrm{Si}, \mathrm{Fe}, \mathrm{Ti}, \mathrm{Ca}$, $\mathrm{K}$, Minor $\mathrm{Zn}$

$\mathrm{U}, \mathrm{Si}$, Minor $\mathrm{Na}$, and $\mathrm{K}$

Broad Energy Continuum

\section{Possible Phases}

Mo-scheelite

Mo-sodalite

Acmite

Aenigmatite

Hydrous alkali uranyl silicate

Boron-rich phase

X-ray diffraction of individual crystals by the precession or Gandolfi methods will be used in the coming year to assign or confirm the actual phases to these typical chemical compositions. 


\subsection{Introduction}

The research described in this report is concerned with the geochemical effects of radioactive decay heat on basalt and with the chemical interactions which might occur if the waste canister were breached during the "thermal perind." The thermal period is that relatively short time when radioactive decay heat is sufficient to raise the temperature of the waste-basalt interface substantially above the natural temperature of the geologic formation. Depending on the waste form, its age out of the reactor and the spacing of canisters in the repository, the thermal period would last for a few hundred years at most, with the highest temperatures occurring during the first 10-20 years. F. H. Jenks (1977) has suggested that the maximum temperatures in rocks adjacent to high-level wastes in a repository might be $-300^{\circ} \mathrm{C}$ for salt and $-400^{\circ} \mathrm{C}$ in shale and other rocks.

We refer to the two chemical processes that can occur during the thermal period as contact metamorphism and waste-basalt interactions. Figure 2.1 illustrates these two cases. Even in the case where the waste remains secure in its protective canister and overpack(s), the 10-200 years of heating can affect the mineralogy and petrology of the nearby rocks. All rocks, to some extent, contain water, both interpore water and structural water, and hydroxyl in their constituent minerals. When combined with other mobile constituents (e.g. halide ions), this mineralizing solution could produce substantial local changes in the rocks over a period of decades with temperatures of only a few hundred degrees. Some of these changes could lead to the formation of such highly adsorptive minerals as clays and zeolites, the existence of which would be important in considerations of long-term isolation of radionuclides. If extraneous water should appear in the immediate repository, then these reactions could be accelerated and the mineralogy could be somewhat different because of the difference in the partial pressure of water $\left(\mathrm{P}_{\mathrm{H}_{2} \mathrm{O}}\right)$.

In the case where the canister somehow becomes breached during the thermal period, there can be alterations of the wastes and mobilization of its constituents by solutions and chemical interactions with the surrounding rocks. The interaction products'would now become the appropriate "source term" for long-duration leaching and nuclide migration studies. 


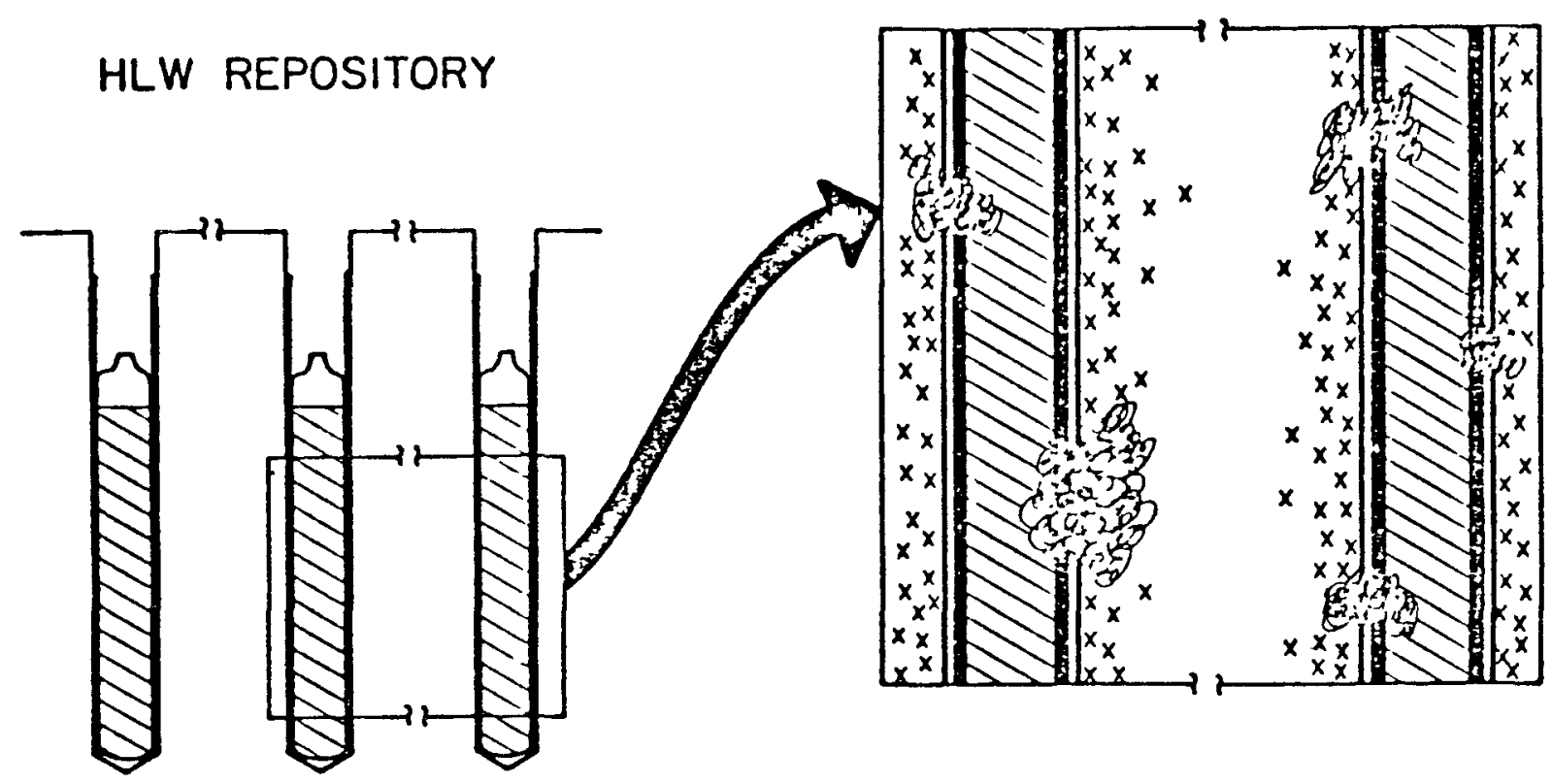

\section{$\$$ WASTE IN CANISTER \\ CONTACT METAMORPHISM \\ WASTE-BASALT INTERACTION}

FIG. 2.1 "Contact Metamorphism" and "Wlaste-Basalt Interactions" are two geochemical reactions that could occur during the thermal period.

The pressure and temperature conditions under which interactions would occur are critical in determining the rates as well as the nature of the products. He have defined five combinations of pressure-temperature $(P-T)$ conditions, with both high and low materials transport, that we believe should be considered in any comprehensive study of waste-basalt chemical interactions. The matrix of conditions is illustrated in Fig. 2.2.

- Type A. Dry-low pressure reoository; "dry heat" without significant pressure in an open cavern.

- Type B. Moving ground water impinges upon the cavern; temperatures are lower because of the cooling by the moving water.

- Type C. The waste-basalt interface is pressurized by the overburden; the only water available is that naturally present in the rocks. 


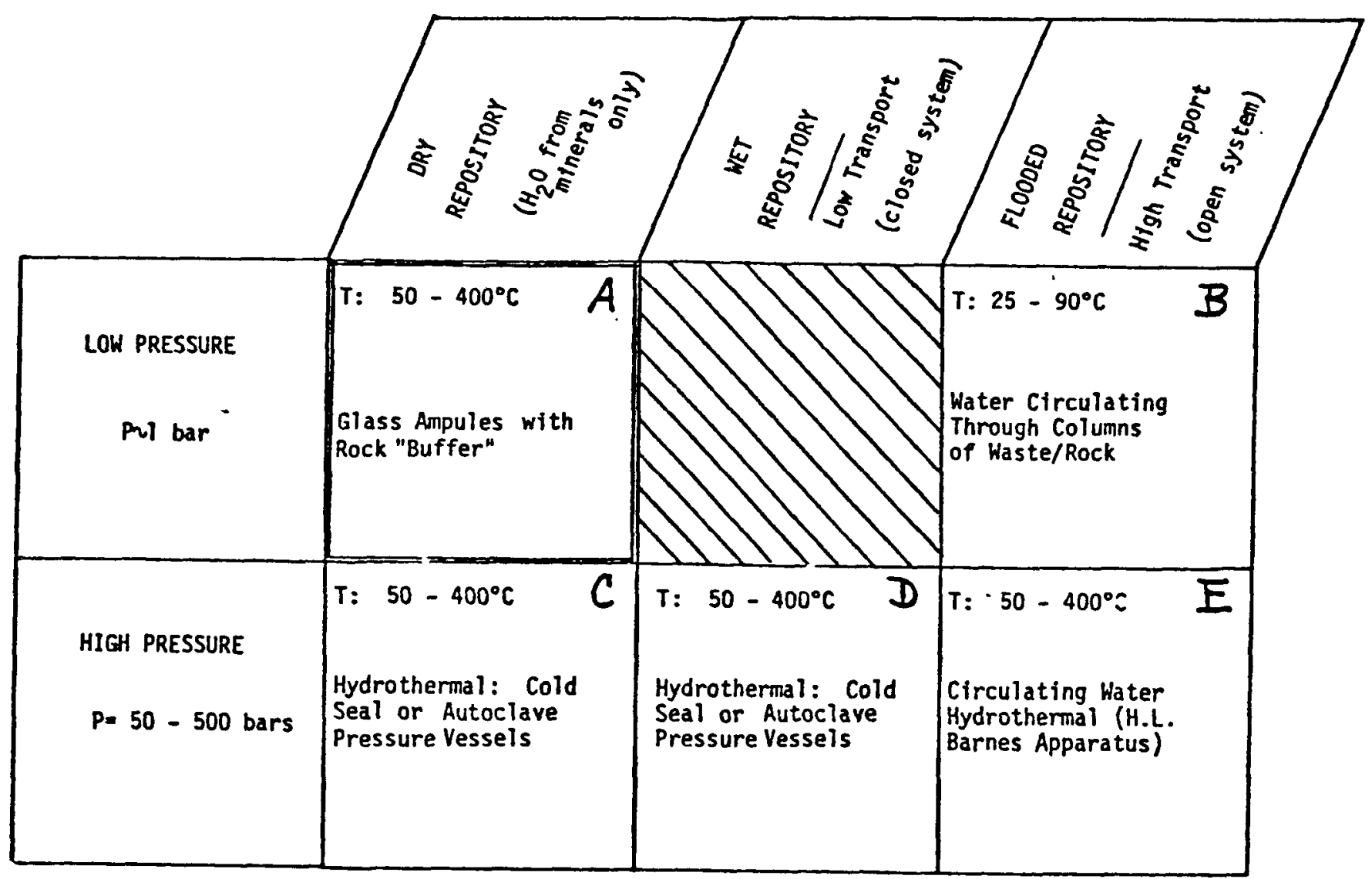

FIG. 2.2 Types of waste-basalt rock interactions experiments.

- Type D. Substantial water has slowly migrated to the pressurized waste-basalt interface; low water transport.

- Type E. Water, pressurized by the overburden, is moving though the waste-basalt interface.

The conditions in Types $C, D$ and $E$ experiments are termed "hydrothermal." From a consideration of geochemical processes one can predict interactions of the high P-T solutions with the rocks, with the waste and with the waste-basalt combinations in a time scale of months or even days.

Also shown in Fig. 2.2 are the equipment types to be utilized for each type of experiment. Types $A, C$ and $D$ experiments are described in detail in Section 5 of this report. Types $B$ and $E$ experiments will be initiated in our Fiscal Year 1978 research program.

The objectives of our eight-month FY 1977 program were five-fold:

- To develop a methodology for waste-basalt interaction studies of types $A, C$ and $D$; 
- To renovate, adapt and expand our hydrothermal facilities to handle the large number of experiments required for a comprehensive program on waste-basalt interaction studies;

- To train technical personnel and students in the rather sophisticated skills required for hydrothermal experimentation;

- To initiate reconnaissance waste-basalt interaction experiments and explore the pressures, temperatures and times required for interactions under types $A, C$ and $D$ conditions;

- To evaluate various tools for characterization of waste-basalt interaction prociucts.

Since otner laboratories may wish to initiate such studies in the coming year or two, we have taken considerable time and space to provide background on the waste and rock types studied (Sections 3 and 4) and on the experimental equipment and procedures utilized (Section 5). Section 6 gives a description of the experiments performed in FY 1977 and preliminary characterization and discussion of the interactions in some of the experiments. 


\subsection{Nuclear Waste Forms}

\section{3.i Introduction}

The present emphasis in the United States' Terminal Storage Program is not to reprocess spent fuel elements. Due to this directive, we are currently considering spent unreprocessed fuel to be our prime radioactive waste form to be stored in a potential basalt cavern.

If the decision were made to reprocess spent fuel with its resultant high-level waste stream, a vitrification process yielding a glass product would probably be the leading contender for the solid waste form, since it is currently receiving the majority of research and development funding. However, calcine has not been ruled out by many investigators and a number of "advanced alternatives" to glass are also receiving some attention.

In order to ensure the comprehensiveness of our current waste-basalt interaction studies, we have chosen to include the following waste forms in our experiments: spent unreprocessed fuel, calcine, glass and supercalcine. The emphasis in our program during fiscal year 1977 was on glass, since at that time it was the leading high-level waste form candidate.

As a first step in analyzing the physical and chemical effects of storing nuclear waste in an underground basalt repository, one must first deal with the waste forms themselves. Needless to say, each waste form has its own set of unique characteristics (chemical and radiological composition, crystalline phases, structure, thermal energy, etc.) which will have a direct bearing upon the storage concept. Fortunately, much of this information is already available in literature. The five-volume Technical Alternatives Document (TAD, 1976) is a comprehensive compilation of data through 1975 on all aspects of the back-end of the nuclear fuel cycle. A recent publication (Deju, et a1., 1977) updates some of the concepts concerning advanced waste forms and also includes an in-depth discussion of the factors governing waste-basalt interaction. Rather than duplicate these efforts once again, we are viewing these reports as a foundation for the discussion which follows.

Note: This section is adapted from a report, "Preliminary Evaluation of the Characteristics of Nuclear Wastes Relevant to Geologic Isolation in Basalt," (RHO-C-12, G. J. McCarthy and M. W. Grutzeck, May 1, 1978, Rockwe11 Hanford Operations, Richland, Washington). 
The purpose of the present document is to review waste form characteristics and to discuss the relevancy of these characteristics upon the concept of storage of nuclear waste in basalt.

\subsubsection{Thermodynamic Stability and Structural State. The structural} state of the components of a waste form is an important and not widely appreciated parameter governing its reactivity. Consider the case of a particular chemical composition that, by variations in processing, can be either rapidly dried from a liquid to give a non-crystalline powder (= calcine), or melted into a glass, or slowly cooled to give the stable crystalline form(s) for that composition. The free energy states of the three solids can be represented schematically as in Fig. 3.1(a).

A fundamental law of chemical reactions states that a reaction proceeds in the direction of lower free energy (G). Fig. 3.1(a) is a schematic representation of the obvious fact that, for a given chemical composition, the calcine and glass forms are unstable with respect to the stable crystalline phase form at the temperature of interest. The calcine and glass have excess free energy compared to the crystalline form due to their more disordered structural states. This is the reason that devitrification (crystallization) studies are such an important part of glass waste form evaluation. It is not enough to evaluate the properties of the metastable glass alone when the possibility exists that the glass will devitrify at some time during its functional lifetime.

Our concern is not with phase changes in a solid from less to more stable forms, but in reactivity in a geologic environment. The disordered structural state which results in excess free energy for calcine and glass can also enhance reactivity. Thermodynamics predicts when a reaction can occur but does not predict that it will occur. There is often a substantial activation energy blocking a thermodynamically favorable reaction. Consider again the three solid forms of the same composition. In Fig. 3.1(b) it is seen that the crystal can undergo some reaction, for example dissolution in water, but a substantial activation energy first needs to be overcome. That activation energy is less for the calcine and glass because of their excess free energy. A clear illustration of this is provided by the work of Hawkins and Roy (1963) on the hydrothermal alteration of basalts. They compared the reactivity of the crystalline basalts with chemically identical glasses and desiccated gels ( calcine) and found that "for a given crystalline rock, glass and gel, all of the same composition 

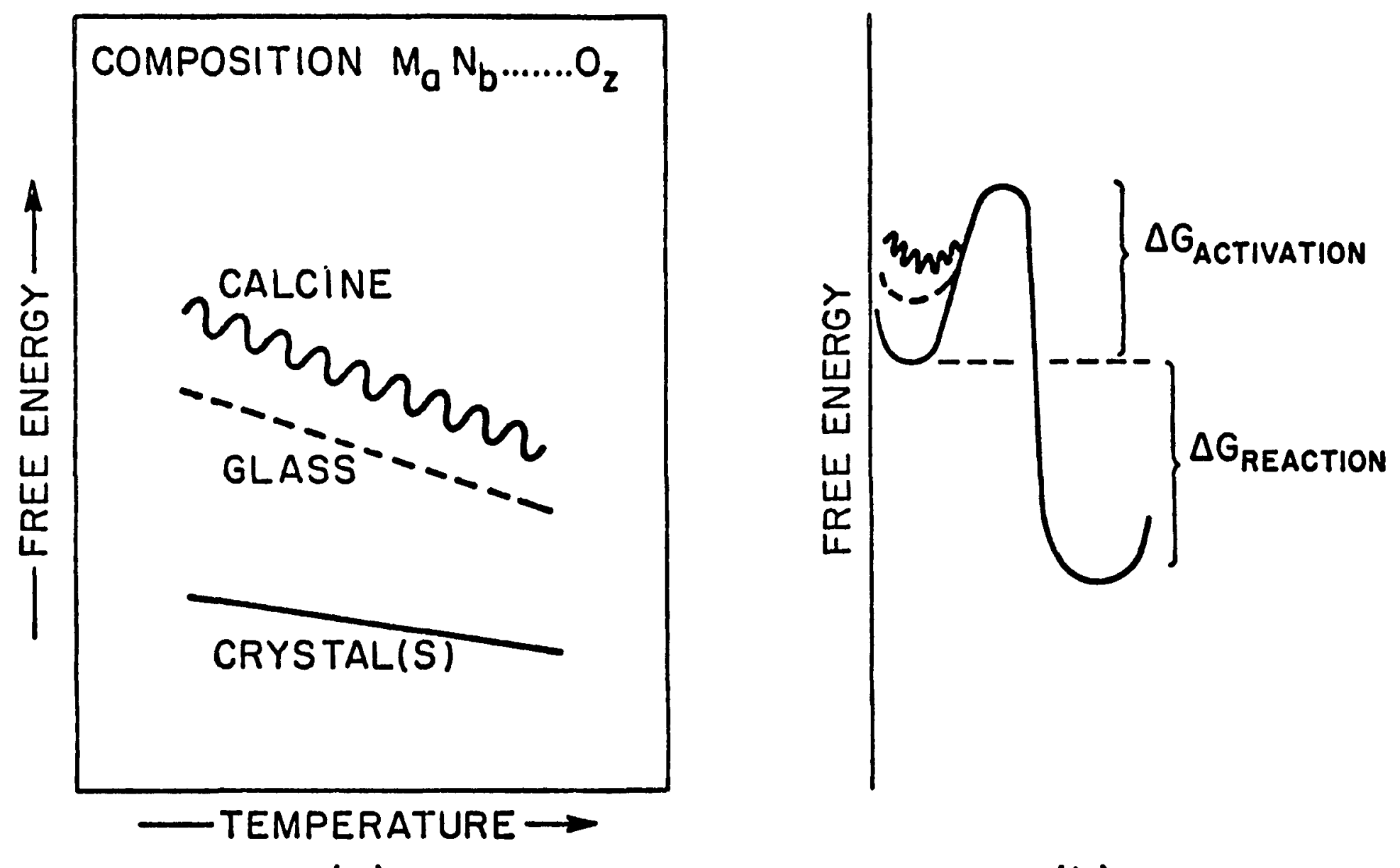

(a)

(b)

FIG. 3.1 (a) Schematic representation for the relative free energies of three solid forms of the same chemical composition.

(b) Schematic representation of the activation energy barrier for a thermodynamically favorable reaction for each of the three solid forms. 
(with other conditions constant...), the glass and gel were readily altered while the crystalline rock was altered only slightly, if at all."

Indeed, desiccated gels and glasses as starting materials have been used for the last three decades of hydrothermal mineralogy and petrology studies because they are so reactive and, therefore, provide a more rapid approach to equilibrium (Roy, 1956).

Another example of why the thermodynamic state of a solid is relevant to waste reactions is illustrated in Fig. 3.2. Phase $A$ has two crystalline forms $\alpha$ and $\beta$. At all temperatures below $T_{t r}$, the phase $\beta$ is metastable and has excess free energy. It is more soluble in water.

Based on the above discussion, it is to be expected that calcine and glass waste forms will be more reactive in the geologic environment than the largely crystalline forms, spent unreprocessed fuel and supercalcine.

Because of the importance of this concept to waste-basalt interactions, the thermodynamic state of the phases (crystalline or noncrystalline) is a major waste form characteristic and will, therefore, be discussed for each of the waste forms.

3.1.2 Chemical Composition. Chemical composition is another important characteristic, since chemical potential differences will provide the major thermodynamic driving force for interactions in the geologic environment and the kinds of ions available determine the types of phases formed.

3.1.3 History of Waste Form: Decay Heat Output. The third important class of characteristics of radioactive waste affecting waste-basalt interactions are the fuel burn-up, the age (i.e., time out of reactor) of the waste, and in some cases waste loading. These determine how much heat is produced by a given volume of radioactive waste. How much heat will be available in the interaction zone of the immediate repository is largely an engineering parameter. Results from our waste-basalt interaction studies may be an important factor in determining how much of a temperature rise should be allowed in the immediate repository and, thus, in the placement of waste canisters.

3.1.4 Leachability. Although considerable data are available under the heading of "leachability," we will not be giving much attention to it in this section. Simply stated, most of the leachability measurements have been taken by the Paige $\left(25^{\circ} \mathrm{C}\right)$, Soxhlet $\left(95^{\circ} \mathrm{C}\right)$, or the International Atomic 

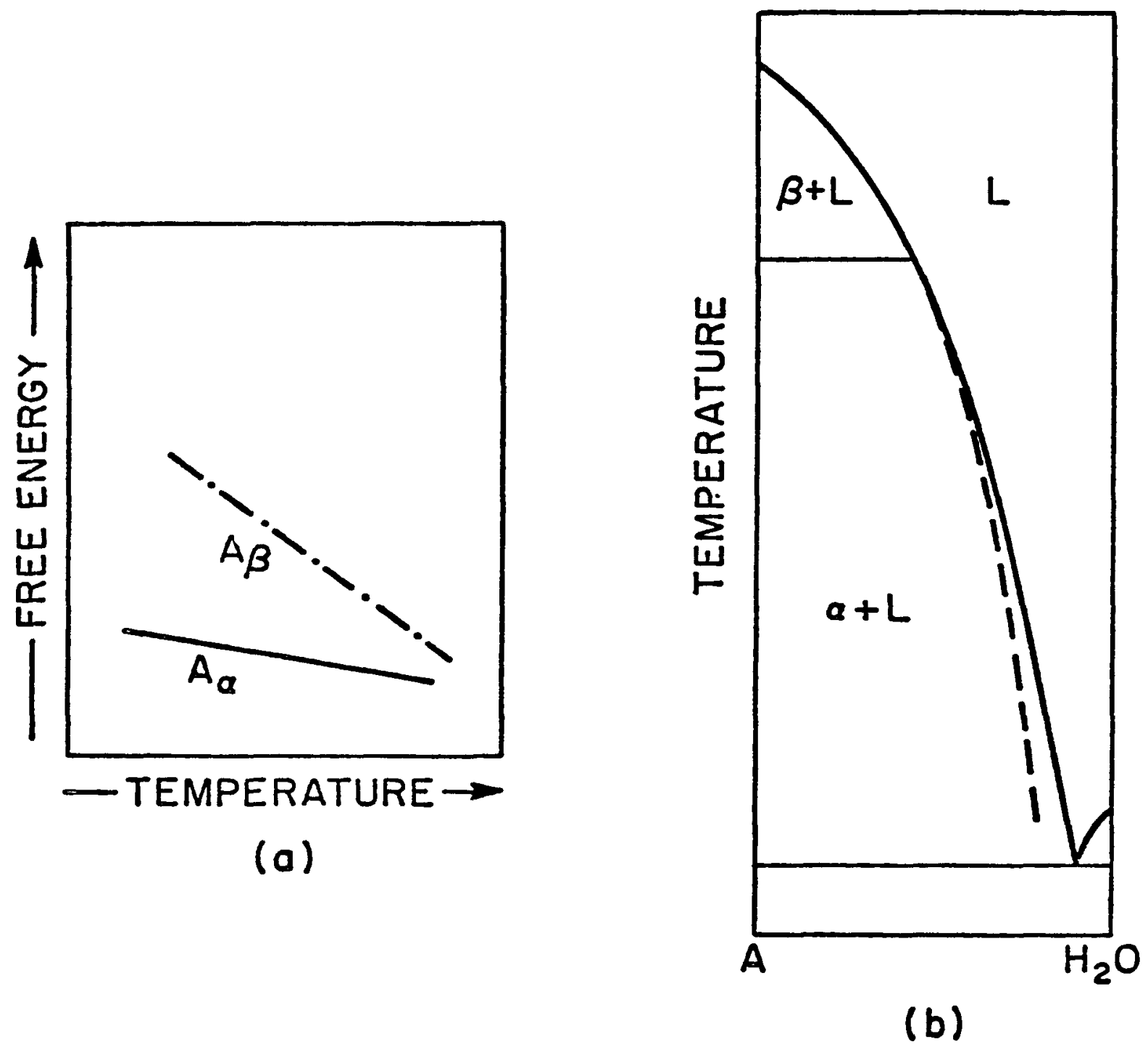

FIG. 3.2 (a) Schematic representation of the free energy of two polymorphs of chemical composition $A . A_{\alpha}$ is the stable phase.

(b) In the phase diagram $A-\mathrm{H}_{2} \mathrm{O}, \mathrm{B}$ is seen to be more soluble in water below the $\alpha \rightleftharpoons \beta$ transition temperature. 
Energy Agency $\left(25^{\circ} \mathrm{C}\right)$ distilled water methods (Mendel, et al., 1977), and are not representative of leaching behavior under the hydrothermal conditions which are of concern in the immediate repository during the thermal period.

3.1.5 Other Characteristics. There are several other types of data having relevance to waste-rock interactions. The surface area per unit mass of the waste form will certainly affect the interaction kinetics. Radiation effects, with their accompanying stored energy, will provide enhanced reactivity to the interactions. However, the magnitude of this contribution should be on the order of a few tens of calories or less, whereas the thermochemical driving force for interactions will be on the order of kilocalories. It should also be pointed out. that the radiation damage will be occurring during the thermal period so that much of it may be annealed out before it can contribute to waste-rock interactions. Finally, it should be noted that solutions impinging on the radioactive waste may be somewhat more reactive than natural hydrothermal solutions due to radiolysis of the water and other constituents.

\subsection{Waste Form Characteristics}

3.2.1 Spent Unreprocessed Fuel. The physical and chemical data needed to evaluate the feasibility of storing spent unreprocessed fuel in a basalt repository are rather limited. However, the thermodynamic state of spent unreprocessed fuel should be governed largely by its phase composition. The major phase is a crystalline fluoride structure consisting largely of $\mathrm{UO}_{2}$, with fluorite-related structure fission product oxides $\left(\mathrm{RE}_{2}^{*} \mathrm{O}_{3}, \mathrm{CeO}_{2}\right.$ and some $\mathrm{ZrO}_{2}$ ) in solid solution. After a survey of some two dozen papers on irradiated fuel behavior, it became clear that very little else is actually known about spent unreprocessed fuel crystalline phase behavior. It is widely believed that $\mathrm{SrO}$ and $\mathrm{BaO}$ react with $\mathrm{ZrO}_{2}$ to form the perovskite structure $\left[(\mathrm{Ba}, \mathrm{Sr}) \mathrm{ZrO}_{3}\right]$. There also appear to be distinct $\mathrm{Cs}-\mathrm{Te}-\mathrm{rich}$ zones. Cesium is thought to be present as cesium molybdates and/or cesium uranates. Spent unreprocessed fuel would have a stability level in the neighborhood of the

* RE is a shorthand notation for a group of rare earth elements. As a group, they exhibit nearly identical chemical properties. This notation allows us to write a general formula which represents the group as a whole. 
crystalline phase depicted in Fig. 3.1(a). Preliminary experiments seem to bear this out, since spent unreprocessed fuel appears fairly unreactive relative to glass and calcine.

We anticipate that the bulk of the $\mathrm{UO}_{2}$-rich spent unreprocessed fuel waste form would remain relatively unreactive under hydrothermal repository ambients as long as the Eh-pH conditions keep the uranium in the tetravalent state. If the conditions become too oxidizing, then the uranium could be readily mobilized and the $\mathrm{UO}_{2}$ would no longer be able to act as a protective matrix for the more soluble fission products and actinides.

Data in Volume I of the Technical Alternatives Document (TAD, 1976) indicate that the composition of a mixed oxide spent unreprocessed fuel having had a burn-up of 25,000 megawatt days per metric ton of heavy fuel is approximately 97 percent $\mathrm{UO}_{2}$ with a balance comprised of fission product and transuranic elements. In order to provide an approximate simulation of the chemistry of spent unreprocessed fuel in early preliminary experiments, we used a mixture of 95 weight percent $\mathrm{UO}_{2}$ plus 5 weight percent $\mathrm{PW}-4 \mathrm{~b}^{\star}$. These were sintered in an attempt to simulate actual spent unreprocessed fuel conditions where the fission products are more typically part of a more complex compound or part of the $\mathrm{UO}_{2}$ solid solution. No effort has been made as yet to include volatiles, especially iodine. Some of the runs. in the future will also contain zircaloy and other alloys in addition to spent unreprocessed fuel and basalt.

There are some leachability data on actual spent unreprocessed fuel (Katayama, 1976), but only the usual $25^{\circ} \mathrm{C}$ data. Hanford ground water, as well as deionized water, were the leachants. The relative leachability of the elements decreases in the order: $\mathrm{Cs}>\mathrm{Sb}>\mathrm{Sr}+\mathrm{Y}>\mathrm{Pu}>\mathrm{Cm}$ with ${ }^{137} \mathrm{Cs}$ leach rates of $\sim 5^{\prime} \times 10^{-6}$ grams per centimeter per day after 21 weeks of testing.

3.2.2 Calcine. Calcine is the general name for unconsolidated powder or granules made by the single-step process of evaporation (and partial decomposition) of liquid high-level waste. In the entire world nuclear picture, high-level waste actually exists in real tonnage only in one solid waste form -calcine. Calcine may have once been considered as a final waste form, but today calcine is typically referred to and considered as an intermediate step before consolidation to, or incorporation into, some other form.

*PW-4b is a simulated low sodium Purex process waste. 
The composition of calcines is very much a function of the reprocessing flow sheet. An ideal or "clean" calcine would have mainly fission product oxides. A flow sheet which calls for mixing the intermediate with the highlevel waste stream will give a calcine with a substantial sodium and phosphate content. The efficiency of separations will determine how much uranium and plutonium remain in the waste stream. The calcine used in our studies is the "dirty"* high-uranium U.S. Department of Energy formulation PW-7a. It was formulated at one time to be typical of the high-level waste from the Barnwell Reprocessing Plant. Table 3.1 lists the compositions of two typical calcines, $\mathrm{PW}-4 \mathrm{~b}$ (clean) and $\mathrm{PW}-7 \mathrm{a}$ (dirty). PW-7a is an especially representative simulated calcine, in that it contains all of the correct chemical elements (except the radioactives: $\mathrm{Tc}, \mathrm{Pm}, \mathrm{Np}, \mathrm{Pu}, \mathrm{Am}, \mathrm{Cm}$ ) including the expensive elements $\mathrm{Pd}, \mathrm{Rh}$, and $\mathrm{Ru}$. It was supplied to us in 1974 as PW-4b by Battelle-Northwest. We have converted it into a PW-7a composition by adding the appropriate amounts of extra $\mathrm{Na},\left(\mathrm{PO}_{4}\right), \mathrm{Fe}$, and $\mathrm{U}$.

The phase compositions of the calcine are important, since the crucial question of the solubility or leachability of hazardous radionuclides is principally determined by the phase into which they are incorporated. Thus, $\mathrm{Sr}^{++}$ in $\mathrm{SrCl}_{2}$ is over a million times more leachable than $\mathrm{Sr}^{++}$in ( $\left.\mathrm{Sr}, \mathrm{Ca}\right) \mathrm{Al}_{2} \mathrm{Si}_{2} \mathrm{O}_{8}$. $X$-ray studies of some calcines would lead one to guess that the typical calcine is a mixture of two or three "phases" each poorly crystallized or nearly noncrystalline. As McCarthy and Davidson (1975a) have shown, crystalline phases can be formed in calcines heated briefly to temperatures above $2950^{\circ} \mathrm{C}$. However, during these firincs, much or all of the $\mathrm{Cs}, \mathrm{Rb}, \mathrm{Na}, \mathrm{Mo}$, Ru and $\mathrm{Te}$ in the calcines are volatilized. This poor thermal stability makes it unlikely that ordinary calcines would be treated at temperatures high enough to crystallize them significantly, even though this would increase their overall thermodynamic stability.

We have heat treated $\mathrm{PW}-7 \mathrm{a}$ at $800^{\circ} \mathrm{C}$ for 2 hours in order to simulate the "stabilization" (i.e., elimination of most of the volatile $\mathrm{NO}_{x}$ and $\mathrm{H}_{2} \mathrm{O}$ ) step which would be used before sealing calcine canisters (TAD, 1976). Even after heating, the calcine remains largely amorphous by $X$-ray diffraction.

*"Dirty" is equivalent to high sodium; "clean" is equivalent to low sodium. 
TABLE 3.1

Compositions of Potential Commercial Reprocessing HLW Calcines (Weight Percent)

\begin{tabular}{|c|c|c|}
\hline Oxide & $\mathrm{PW}-4 \mathrm{~b}($ (Clean") & PW-7a ("Dirty")* \\
\hline $\mathrm{Na}_{2} \mathrm{O}$ & - & 9.1 \\
\hline $\mathrm{P}_{2} \mathrm{O}_{5}$ & 1.6 & 8.3 \\
\hline $\mathrm{RE}_{2} \mathrm{O}_{3}$ *ᄎ & 31.8 & 30.5 \\
\hline $\mathrm{ZrO}_{2}$ & 12.1 & 6.5 \\
\hline $\mathrm{MoO}_{3}$ & 12.6 & 6.8 \\
\hline $\mathrm{Tc}_{2} \mathrm{O}_{7}$ & 3.2 & 1.7 \\
\hline $\mathrm{RuO}_{2}$ & 7.3 & 3.9 \\
\hline PdO & 3.6 & 2.0 \\
\hline $\mathrm{Cs}_{2} \mathrm{O}$ & 7.0 & 3.8 \\
\hline $\mathrm{Rb}_{2} \mathrm{O}$ & 0.9 & 0.5 \\
\hline Sro & 2.6 & 1.4 \\
\hline $\mathrm{BaO}$ & 3.8 & 2.1 \\
\hline$U_{3} O_{8}$ & 2.9 & 15.4 \\
\hline $\mathrm{Rb}_{2} \mathrm{O}$ & 0.9 & 0.5 \\
\hline $\mathrm{TeO}_{2}$ & 1.8 & 1.0 \\
\hline $\mathrm{Fe}_{2} \mathrm{O}_{3}$ & 3.7 & 4.0 \\
\hline $\mathrm{Cr}_{2} \mathrm{O}_{3}$ & 0.8 & 0.5 \\
\hline NiO & 0.3 & 0.2 \\
\hline $\mathrm{PuO}_{2}$ & 0.2 & 0.1 \\
\hline others & 2.7 & 1.6 \\
\hline
\end{tabular}

*Calculated from data in Table 2 of Mendel et al., (1977). $\star \star R E=L a, C e, P r, N d, P m, S m, E u, G d, T b, D y, Y$. 
"Leachability" of calcine, even in room temperature water, would be expected to be high because of its high surface area per unit mass and the iikely presence of water soluble "phases;" e.g., ( $\mathrm{Na}, \mathrm{Cs})_{2} \mathrm{MoO}_{4}$. Mendel and McElroy (1972) report that 20 to 25 percent of the constituents of a typical calcine dissolve readily on contact with water. This means that a substantial fraction of a calcine will be immediately available in solution during hydrothermal waste-basait interaction experiments.

"Waste. loading" in calcine is essentially 100 percent. However, in a canister the amount of the low-density calcine $(\approx 1$ gram per cubic centimeter) would be equivalent to another product of higher density (3.0 grams per cubic centimeter) with 33 weight percent loading.

\subsubsection{Glass. Development of vitrification processes for solidifica-} tion of high-level waste began more than two decades ago in the United States and abroad. As far back as ten years ago, a pilot-scale hot demonstration of phosphate and borosilicate glass processing was under way at the Hanford site (the Waste Solidification Engineering Prototypes Program). In the future, Battelle-Northwest will be demonstrating in-can solidification by vitrification of actual high-level waste made by onsite reprocessing of spent fuel. Clearly, glass was the waste form closest to utilization for the near term, and for this reason, it was initially given the greatest consideration in our wastebasalt interactions program.

It is widely appreciated that glass is in an excess free energy state compared to the assemblage of equilibrium crystalline phases of the same bulk composition. It is for this reason that high-level waste glasses are subject to "devitrification" (partial crystallization) on slow cooling and when held in the temperature range of 500 to $800^{\circ} \mathrm{C}$. The Battelle-Northwest Reference Glass 72-68 has been shown to devitrify into ( $\mathrm{Ca}, \mathrm{Sr}, \mathrm{Ba}) \mathrm{MoO}_{4}, \mathrm{Zn}_{2} \mathrm{SiO}_{4}$, $(\mathrm{Zn}, \mathrm{Ni})(\mathrm{Fe}, \mathrm{Cr})_{2} \mathrm{O}_{4}$, and $\mathrm{Ca}_{2} \mathrm{RE}_{8}^{*}\left(\mathrm{SiO}_{4}\right)_{6} \mathrm{O}_{2}$ after these therma 1 treatments. In addition, crystalline $\mathrm{RuO}_{2},(\mathrm{Ce} \ldots)_{2}$ and $\mathrm{Pd}$ were also present in the freshly formed glass as undissolved components (Mendel, et al., 1977).

In our laboratory hitherto unreported glass-in-glass phase separation by transmission electron microscopy has been observed.

High-level waste "glass" falls between glass and crystal in Fig. 3.1 (a). Thus we would expect glass to be intermediate in reactivity between calcine and the more completely crystallized supercalcine and spent unreprocessed fuel during our waste-basalt interaction studies. 
TABLE 3.2

COMPOSITION OF BATTELLE-NORTHWEST GLASS 76-68

\begin{tabular}{|c|c|c|c|c|c|}
\hline Oxide & wt z & Oxide & Wt 8 & Oxide & Wt $q$ \\
\hline $\mathrm{SiO}_{2}$ & 39.8 & $\mathrm{MOO}_{3}$ & 2.3 & $\mathrm{P}_{2} \mathrm{O}_{5}$ & 0.5 \\
\hline $\mathrm{Na}_{2} \mathrm{O}$ & 12.5 & $\mathrm{CaO}$ & 2.0 & $\mathrm{Cr}_{2} \mathrm{O}_{3}$ & 0.4 \\
\hline $\mathrm{Fe}_{2} \mathrm{O}_{3}$ & 9.8 & $\mathrm{ZrO}_{2}$ & 1.8 & Sro & 0.4 \\
\hline $\mathrm{B}_{2} \mathrm{O}_{3}$ & 9.5 & $\mathrm{CeO}_{2}$ & 1.2 & $\mathrm{TeO}_{2}$ & 0.3 \\
\hline $\mathrm{znO}$ & 5.0 & $\mathrm{RuO}_{2}$ & 1.1 & NiO & 0.2 \\
\hline $\mathrm{U}_{3} \mathrm{O}_{8}$ & 4.6 & $\mathrm{Cs}_{2} \mathrm{O}$ & 1.0 & $\mathrm{Rh}_{2} \mathrm{O}_{3}$ & 0.2 \\
\hline $\mathrm{RE}_{2} \mathrm{O}_{3}$ ** & 3.4 & $\mathrm{BaO}$ & 0.6 & $\mathrm{Rb}_{2} \mathrm{O}$ & 0.1 \\
\hline $\mathrm{TiO}_{2}$ & 3.0 & Pdo & 0.5 & Others & 0.1 \\
\hline
\end{tabular}

*Modified from a table provided by D. Bradley, Battelle-Northwest, Richland, Washington.

${ }^{\star}{ }^{R E}=\mathrm{La}, \mathrm{Pr}, \mathrm{Nd}, \mathrm{Sm}, \mathrm{Eu}, \mathrm{Gd}, \mathrm{Y}$. 
The specific glass we have chosen in our interaction studies is exactly the same as the reference glass being used in the source term characterization task of the Office of Waste Isolation/Battelle-Northwest/Waste Isolation Safety Assessment Program. Its code is 76-68 and the specimen was provided by J. E. Mendel of Battelie-Northwest. With regard to the above discussion on devitrification, it should be noted that 76-68 shows significantly less devitrification than 72-68 (Turcott and Wald, 1977). Only Ru, $\mathrm{RuO}_{2}$, two spinel phases, and $(U, \mathrm{Ce} ..) \mathrm{O}_{2 \pm x}$ have been noted to date in heattreated 76-68.

The composition of Glass $76-68$ is given in Table 3.2. The waste composition (PW-8a) used to prepare Glass 76-68 was calculated to be typical of one of the high-level wastes to have been generated by the now defunct Nuclear Fuel Services Reprocessing Plant. PW-8a is similar in composition to PW-7a (Table 3.1), except that it has $\sim 2$ times the $\mathrm{Na}$ and $\sim 9$ times the Fe. PW-8a was combined with a glass-making frit, which can be described as a soda-lime-zinc-titanium borosilicate. It should be noted that this simulated high-level waste glass composition (76-68) is as representative as it can be without including the radioactive elements. In Table 3.2 the oxides have been listed in order of decreasing concentration. The molybdenum oxide is $\sim 20$ percent greater than it would be in actual high-level waste, because Mo has been used as a "stand-in" for Tc. Waste loading in 76-68 is 33 weight \% of $\mathrm{PW}-8 \mathrm{a}$ calcine, which is equivalent to 13 weight \% fission product oxides.

3.2.4 Supercalcine. McCarthy, et al., (1975b, 1977a, 1977b) have described the first successful supercalcine formulations. The basic premise of this tailor-made ceramic is that modifications can be made to high-level liquid waste compositions through the addition of selected liquid additives so that when the liquid is calcined and given additional heat treatment, an assemblage of refractory and leach-resistant phases is crystallized. The name "supercalcine" was coined to indicate a common processing operation with "calcine." An important component of this research has been the collaboration with BattelleNorthwest where engineering-scale "cold" demonstrations and product characterizations have been performed.

To date, McCarthy and his co-workers have succeeded in the development of effective formulations for converting both "clean" and "dirty" high-level liquid waste (see Table 3.1) into compatible assemblages of refractory and leach-resistant phases. Table 3.3 lists these phases and structure types. 
TABLE 3.3

FIXATION PHASES FOR HIGH-LEVEL WASTE

CONSTITUENTS IN SUPERCALCINE

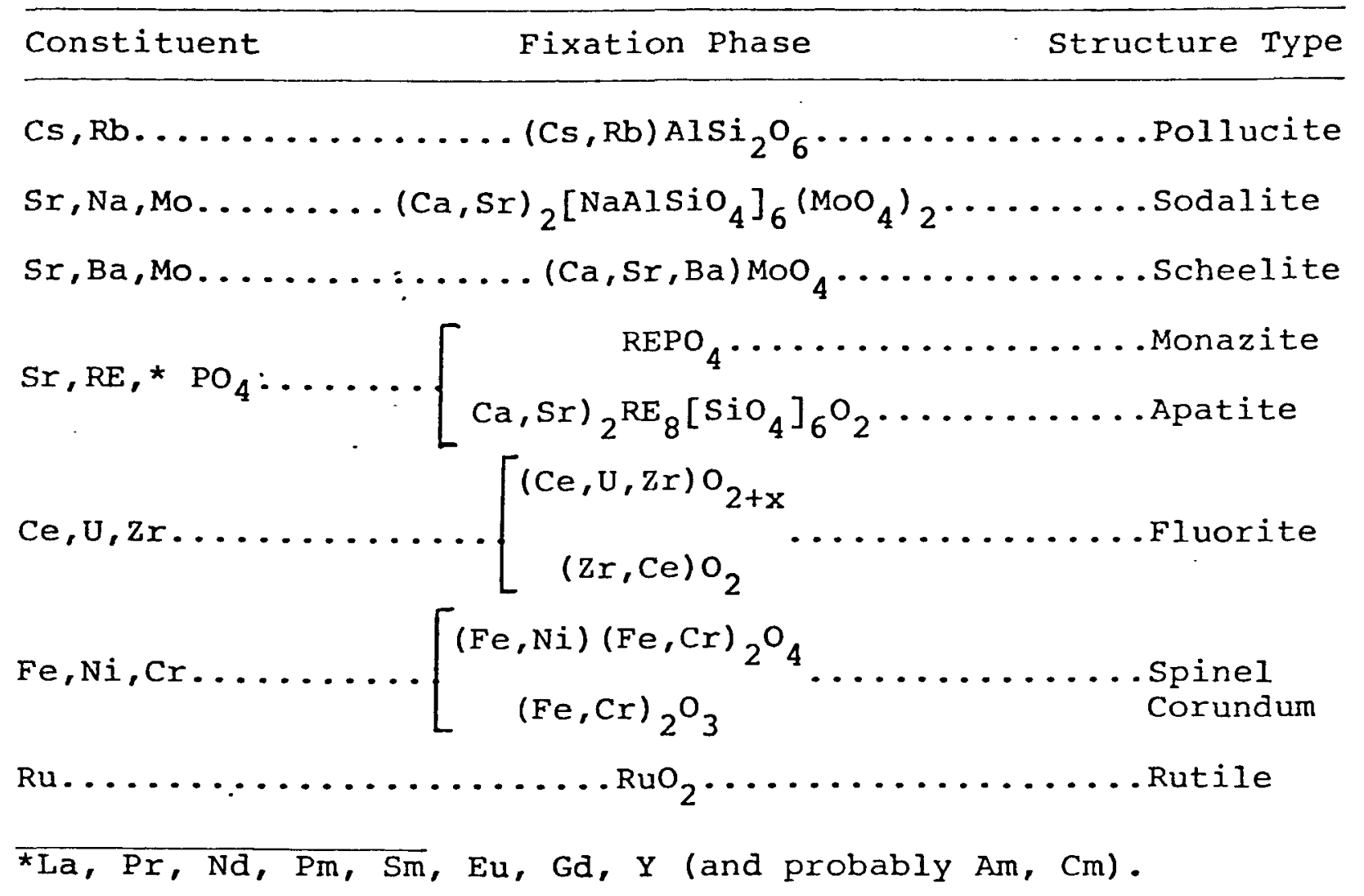


The mix of phases differs with the waste composition. Additions of nitrates of $\mathrm{Ca}, \mathrm{Sr}$, and $\mathrm{Al}$, plus soluble forms of silica, are made to the high-level liquid wastes. These additions give a dilution by only 20 to 40 weight percent of unmodified high-level wasce calcine. To date, three engineering-scale demonstrations of supercalcine preparation by spray calcination have been routinely performed at Battelle-Northwest. Spray supercalcine is $X$-ray amorphous and must be heated briefly above $950^{\circ} \mathrm{C}$ to "develop" the assemblage of crystalline phases. The Technical Alternatives Document (TAD, 1976) states that "if an unconsolidated calcine continues to be an acceptable waste form, supercalcine formulation concepts can be introduced into flow sheets immediately which would improve the stability and insolubility of some of the radioactive waste consituents." However, current emphasis is on developing monolithic forms of supercalcine and recent tests of 5- to 10-millimeter spherical pellets encased in a metal matrix have been very encouraging (J. M. Rusin, Battelle-Northwest).

The free energy state of supercalcine in-canister is not at the exact minimum as might be expected from its definition. One reason is the structural disorder in certain supercalcine phases that is introduced by radiation and transmutation of effects. A second reason is that excess additives are included in each formulation to allow for compositional variation in the realistic highlevel liquid waste streams. Thus, enough excess $\mathrm{Al}+\mathrm{Si}$ is added to crystallize twice the Cs normally present in a reprocessing plant's high-level liquid waste composition. Much of this excess alumina plus silica remains as a non-crystalline phase after the brief crystallization heat treatment and keeps a real supercalcine from attaining minimum free energy for its particular composition. However, it has been established that the 94 to 97 weight percent of the supercalcine product that is crystalline is in "effective" equilibrium when formed. Thus, one formulation (SPC-2) has been fired for weeks at $900^{\circ} \mathrm{C}$ without modifying the assemblage of nine compatible crystalline phases.

The specific formulation being used in our reconnaissance waste-basalt interactions studies is SPC-2. It was prepared according to McCarthy's formulation (1977c) on the spray calciner at Battelle-Northwest and crystallized by firing at $1,125^{\circ} \mathrm{C}$ for 2 to 4 hours. The crystalline phases and their shorthand notations in SPC-2 are:

$\begin{array}{llll}\mathrm{Ca}_{2} \mathrm{RE}_{8}\left(\mathrm{SiO}_{4}\right)_{6} \mathrm{O}_{2} & {\left[\mathrm{~A}_{\mathrm{SS}}\right]} & (\mathrm{Cs}, \mathrm{Rb}, \mathrm{Na}) \mathrm{AlSi}_{2} \mathrm{O}_{6} & {[\mathrm{P}]} \\ \mathrm{REPO}_{4} & {\left[\mathrm{M}_{\mathrm{SS}}\right]} & \left(\mathrm{Ce}, \mathrm{Zr} \ldots \mathrm{O}_{2}\right. & {\left[\mathrm{F} \mathrm{Ss}_{2}\right]} \\ \text { Tetragonal }-\mathrm{ZrO}_{2} & {\left[\mathrm{~T}_{\mathrm{SS}}\right]} & (\mathrm{Fe}, \mathrm{Cr})_{2} \mathrm{O}_{3} & {\left[\left(\mathrm{Fe}_{2} \mathrm{O}_{3}\right)_{\mathrm{sS}}\right]} \\ (\mathrm{Ca}, \mathrm{Sr}, \mathrm{Ba}) \mathrm{MoO}_{4} & {\left[\mathrm{~S}_{\mathrm{SS}}\right]} & (\mathrm{Ni}, \mathrm{Fe})(\mathrm{Fe}, \mathrm{Cr})_{2} \mathrm{O}_{4} & {\left[\mathrm{SP}_{\mathrm{SS}}\right]}\end{array}$


The complete composition of SPC-2 oxides is given in Table 3.4, and a portion of an X-ray diffractogram of crystallized SPC-2 is shown in Fig. 3.3.

It has been stated that supercalcine phases are in effective equilibrium when formed and at the temperature expected in-canister for stored high-level waste $\left(<800^{\circ} \mathrm{C}\right)$. More relevant in the context of our waste-basalt interaction studies is whether these phases will be in equilibrium with each other and with the surrounding rocks under the hydrothermal conditions which could be typical of a geologic repository. Our expectation is that some phases will be and some will not. Many of the mineral phases listed in Table 3.4 are found in nature in hydrothermally formed igneous rocks. Thus, it is very likely that these minerals will be stable in hydrothermal environments at temperatures approximating their crystallization temperatures. Pollucite (CsAlsi $\left.{ }_{2} \mathrm{O}_{6}\right)$, for example, is only formed in nature under hydrothermal conditions. Indeed, we would even expect pollucite to be a hydrothermal interaction product when the wastes are as reactive as calcine or glass (and, thus, readily give up their (s) and when the rocks contain alumina and silica. Furthermore, according to the earlier discussion on reactivity of crystalline waste forms, those supercalcine crystalline phases that are not in equilibrium in the hydrothermal geologic environment would be expected to react quite slowly with any solutions. 
TABLE 3.4

Composition of Supercalcine SPC-2

\begin{tabular}{|c|c|c|c|c|c|}
\hline Ion & Molarity & Oxide & $\begin{array}{l}9 \text { Oxide per liter } \\
\text { of Calcined SPC-2 }\end{array}$ & Height & Percent Oxide \\
\hline \multicolumn{6}{|c|}{ Exom the modified $P W-7$ wasts: } \\
\hline ce & 0.161 & $\mathrm{CeO}_{2}$ & 27.7 & 16.3 & $(12.7)^{8}$ \\
\hline $2 r$ & 0.106 & $\mathrm{ZrO}_{2}$ & 13.0 & 7.6 & $(5.9)$ \\
\hline$R E^{b}$ & $0.102^{b}$ & $\mathrm{RE}_{2} \mathrm{O}_{3}$ & 17.1 & 10.0 & $(7.8)$ \\
\hline $\mathrm{Fe}$ & 0.100 & $\mathrm{Fe}_{2} \mathrm{O}_{3}$ & 8.0 & 4.7 & $(3.7)$ \\
\hline$\left[\mathrm{PO}_{4}\right]$ & 0.100 & $\mathrm{P}_{2} \mathrm{O}_{5}$ & 7.1 & .4 .2 & $(3.2)$ \\
\hline Mo & 0.095 & $\mathrm{MOO}_{3}$ & 13.7 & 8.0 & $(6.3)$ \\
\hline La & 0.094 & $\mathrm{La}_{2} \mathrm{O}_{3}$ & 15.3 & 9.0 & $(7.0)$ \\
\hline Cs & 0.054 & $\mathrm{Cs}_{2} \mathrm{O}$ & 7.6 & 4.5 & $(3.5)$ \\
\hline Sr & 0.027 & sro & 2.8 & 1.6 & $(1.3)$ \\
\hline Ba & 0.027 & BaO & 4.1 & 2.4 & $(1.9)$ \\
\hline $\mathrm{Cr}$ & 0.012 & $\mathrm{Cr}_{2} \mathrm{O}_{3}$ & 0.9 & 0.5 & $(0.4)$ \\
\hline $\mathbf{R B}$ & 0.010 & $\mathrm{Rb}_{2} \mathrm{O}$ & 0.9 & 0.5 & $(0.4)$ \\
\hline $\mathrm{Ma}$ & 0.010 & $\mathrm{Na}_{2} \mathrm{O}$ & 0.3 & 0.2 & $(0.1)$ \\
\hline$R u^{c}$ & 0.006 & $\mathrm{RuO}_{2}$ & 0.8 & 0.5 & $(0.4)$ \\
\hline N1 & 0.005 & N10 & 0.4 & 0.2 & $(0.2)$ \\
\hline cd & 0.002 & $\operatorname{cdo}$ & 0.3 & 0.2 & $(0.1)$ \\
\hline
\end{tabular}

moercalcine additives:

$\begin{array}{lllccc}\text { S1 } & 0.539 & \mathrm{SHO}_{2} & 32.4 & 19.1 & (14.8) \\ \mathrm{Cr} & 0.150 & \mathrm{CaO}^{2} & 8.4 & 4.9 & (3.8) \\ \mathrm{Al} & 0.148 & \mathrm{Al}_{2} \mathrm{O}_{3} & 7.5 & 4.4 & (3.4) \\ \mathrm{Sr} & 0.020 & \mathrm{SrO}^{2} & \frac{2.1}{170.4} \mathrm{~g} \text { oxtdes } & \frac{1.2}{100.07} & (1.0)\end{array}$

(70.5\% waste loading)

other waste constituents ${ }^{d}$ :

$\begin{array}{lllll}U(P u, N p) & 0.1195 & \mathrm{U}_{3} \mathrm{O}_{8} & 33.6 & (15.5) \\ \text { Ruc } & 0.053 & \mathrm{RuO}_{2} & 7.1 & (3.2) \\ \text { Pd } & 0.032 & \mathrm{PdO}^{2} & 3.9 & (1.8) \\ \text { Te } & 0.012 & \mathrm{TeO}_{2} & 1.9 & (0.9) \\ \text { Rh } & 0.010 & \mathrm{Rh}_{2} \mathrm{O}_{3} & 1.3 & (0.6) \\ \text { Ag } & 0.002 & \mathrm{AgO}^{-10} & 0.3 & (0.1) \\ & & & 218.5 \mathrm{~g} \text { oxides } & (100.0 \%)\end{array}$

(76.98 kaste loading)

a value in parentheses is the wt\% of the oxide after addition of the appropriate amounts of U, Ru, Pd, Te, Rh, Ag.

D RE=0.061 Nd $+0.019 \mathrm{Pr}+0.011 \mathrm{Sm}+0.007 \mathrm{Gd}+0.003$ Y (Note: $0.002 \mathrm{RE}$ is a stand-in for Am+Cm)

C Ru concentration in the spray supercalcine SPC-2 was $10 \%$ of the actual PX-7 value of 0.059 M. The addition of the renaining $0.053 \mathrm{M}$ was made after calcination.

These constituents were not included in the large batch of SPC-2 because of their expense or radioactivity. Hone require fixation addftives. The only PH-7 constituent not included above is TC. 


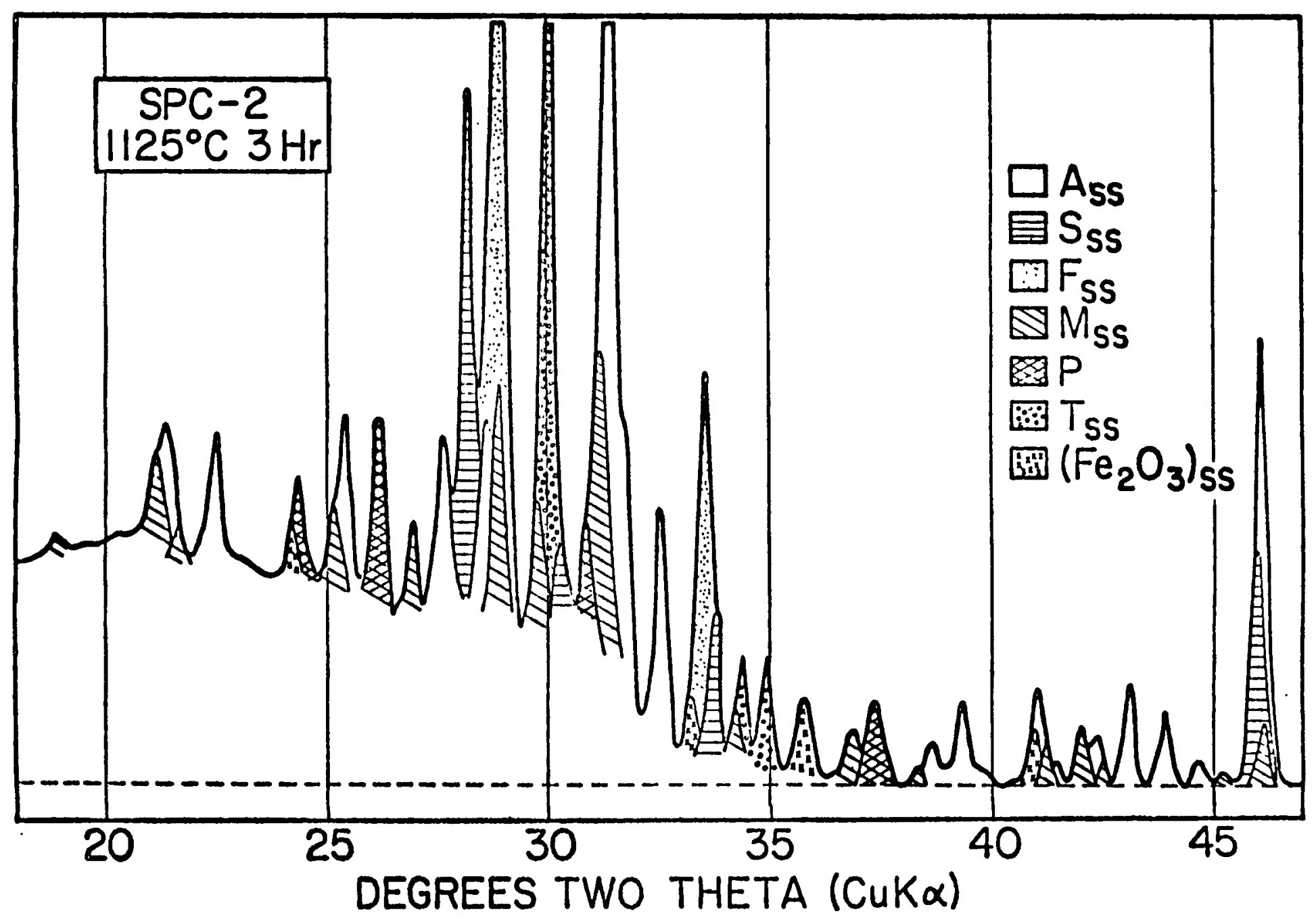

FIG. 3.3 Portion of the X-ray diffractogram of supercaicine SPC-2. The shorthand notation of the

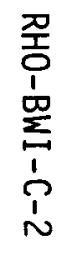
crystalline phases is explained in the text. 


\subsection{Basalts}

\subsection{Columbia River/Hanford Basalts}

Five Columbia River Basalt samples were initially incorporated into the reaction matrix for this study. The first four have the following Rockwell Hanford Operations identifications.
$B C R-1$
$\mathrm{DH}-4 / \mathrm{A4} 104 / 2398$
$\mathrm{DDH}-3 / \mathrm{A2} 120 / 3320$
DH-5/A5122/3096

Core samples of $\mathrm{DDH}-3, \mathrm{DH}-4$ and $\mathrm{DH}-5$ were chosen to correspond to depth intervals believed to be Umtanum Basalt flows by Rockwell Hanford Operations geologists. These samples and the BCR-1 sample, a USGS international standard, were supplied by Rockwell Hanford Operations personnel. A fifth sample, "Umtanum Pillow Basalt" (UPB), was collected from the top of the Umtanum flow at Sentinel Gap during a field trip in early 1977.

4.1.1 BCR-1. A complete chemical analysis as oxides and a complete trace elemental analysis was published by the USGS. These values are presented in Table 4.1. A detailed mineralogical analys is is apparently not available for the BCR-1 sample.

\subsubsection{Hanford Basalts. Survey mineralogical and petrographic} analysis for two of the four samples initially considered in this study were provided by $C$. W. Myers. Sample DDH-3 shows the usual microphenocrysts of plagioclase $(0.7 \mathrm{~mm}$ long) with rounded grains, tabular clotted plates plus rare microphenocrysts of green pyroxene, large euhedral opaques and a deep brown glass which is nearly clear except for a spattering of tiny spherical opaques. The sample contains only a little chlorophaeite. The modal analysis of $\mathrm{DDH}-3$ is:

\begin{tabular}{lc} 
Minerals & Volume \% \\
\cline { 2 - 2 } plagioclase & 38.6 \\
pyroxene & 38.9 \\
olivine & \\
$\quad$ (saponitized) & 0.2 \\
opaques & 7.6 \\
glass + crystallites & 14.4 \\
apatite & 0.3
\end{tabular}




\section{TABLE 4.1}

Chemical Analysis of BCR-1

USGS-BCR-1

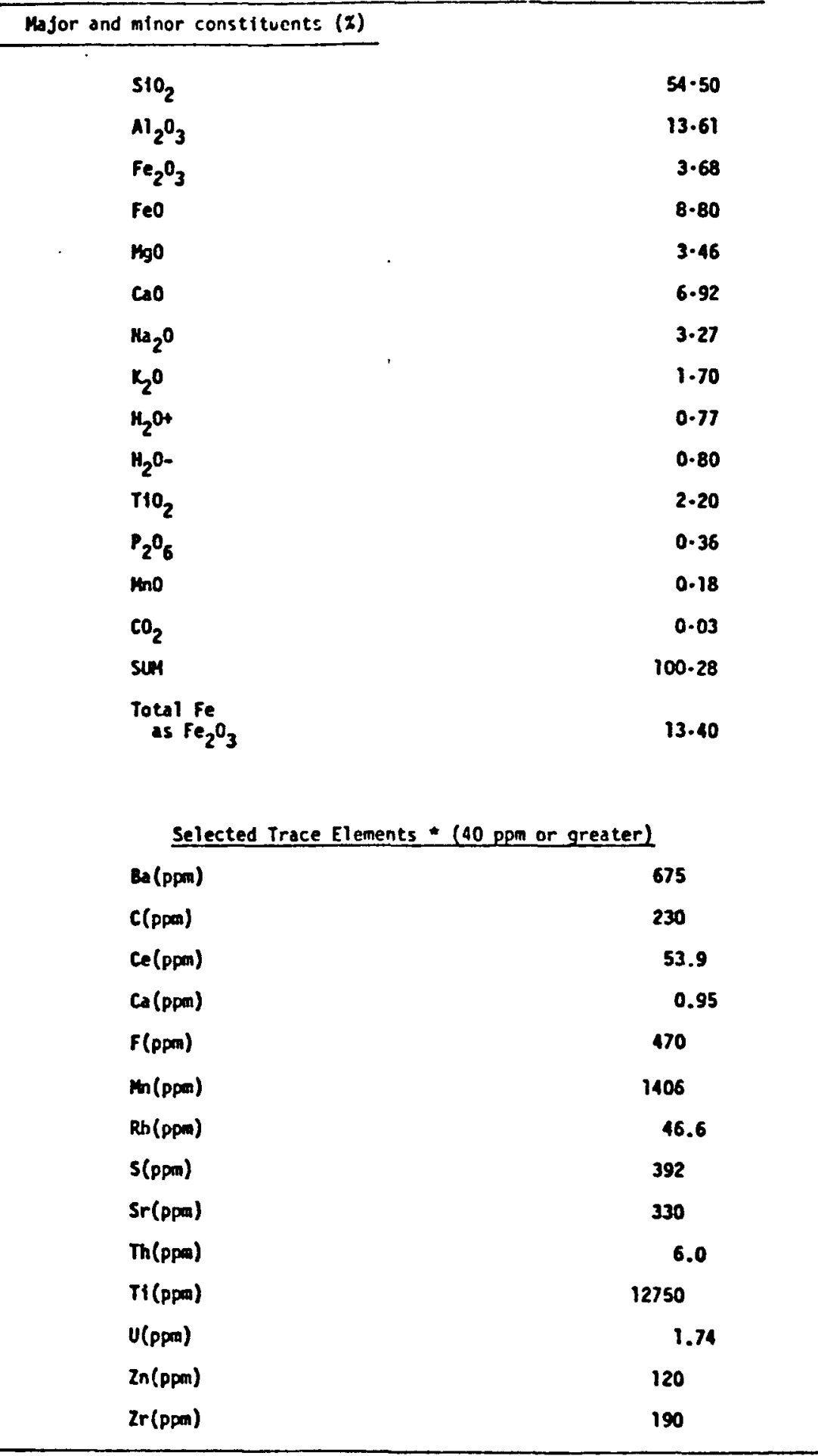

- Ag, As, Au, B, Be, Bl, Br, Cd, Cl, Co, Cr, Cu, Dy, Er, [u, Ga, Gd, Ge, Hf, Hg, Mo, I, In, Ir, La, LI, Lu, Mo, N, Nb, Nd, NI, O, Os, Pb, Pd, Pr, Pt, Ra, Re, Rh, Ru, St, Sc, Co, Sm, Sn, Ta, Tb, Te, It, Tm, Y, H, Y, Yb. 
No chemical analysis of this specific sample is presently available. However, the analysis given in Table 4.2 has been presented by Mr. L. L. Ames, Battelle-Northwest, in 1976 for a sample taken from the same core, DDH-3, A2109, and is believed to be representative of the Umtanum Basalt.

In a second sample, $\mathrm{DH}-4$, it has been reported that small microphenocrysts of plagioclase $(0.3 \mathrm{~mm}$ long) and, rarely, of pyroxene $(0.1 \mathrm{~mm}$ long) were present. Tiny microlites of plagioclase (up to $0.15 \mathrm{~mm}$ long) and pyroxene grains (mostly less than $0.02 \mathrm{~mm}$ ) were enclosed in black tachylyte which contained some crosses and other skeletal opaques; some less crystallized glass was därk brown. Orange-brown clay along incipient platey joints was observed. A clear yellow-green chlorophaeite lined the vesicles. The sample was not really suitable for point counting because of its high content of tachylyte. Only 500 points were counted. A vein filling in the slide was not counted. Thus, only a rough modal analysis was obtained.

\begin{tabular}{lc} 
Minerals & Volume \% \\
\cline { 2 - 2 } plagioclase & 17.4 \\
pyroxene & 16.0 \\
tachylyte & 65.4 \\
$\begin{array}{c}\text { chlorophaeite } \\
\text { (fresh) }\end{array}$ & 1.2
\end{tabular}

No analytical information is available yet on this sample.

Nothing in the way of chemical or mineralogical analyses are currently available for DH-5/A5122/3096 or UPB.

\subsection{Pressure-Temperature Effects on Basalts}

We noted in the introduction that the presence of a radioactive waste heat source in the vicinity of the load-bearing; i.e., pressurized, basalt can result in contact metamorohism which, in turn, should affect the behavior of these near-repository rocks in regard to the migration of radionuclides. If water should intrude on the repository in the thermal period, then significant changes in the basalts are even more likely. Some information on what these changes might be is suggested by the petrogenic grid shown in Fig. 4.1 . 
TABLE 4.2

Electron Microprobe Analys is of DDH-3/A2109 -- "Umtanum" Basalt Feldspar-based on the unit cell $(\mathrm{Na}, \mathrm{K}, \mathrm{Ca}, \mathrm{Ba})_{4}(\mathrm{Si}, \mathrm{Al}){ }_{16} \mathrm{O}_{32}$

\begin{tabular}{|c|c|c|c|c|c|c|c|c|}
\hline \multirow[b]{2}{*}{ Sample } & \multicolumn{8}{|c|}{ Unit cell Contents } \\
\hline & $\underline{s i}$ & Al & $\underline{S i+A l}$ & $\underline{c a}$ & $\underline{K}$ & Mn & $\mathrm{Ba}$ & 等, Ba \\
\hline A2109 & 10.269 & 5.597 & 15.866 & 1.924 & 0.117 & 2.167 & $\ldots$ & 4.208 \\
\hline 12109 & 10.310 & 5.618 & 15.928 & 1.620 & 0.179 & 2.488 & $\ldots$ & 4.287 \\
\hline A2109 & 10.117 & 5.971 & 16.088 & 1.872 & 0.114 & 1.763 & - & 3.779 \\
\hline A2109 & 10.357 & 5.616 & 15.973 & 1.845 & 0.117 & 1,918 & - & 3.880 \\
\hline
\end{tabular}

Molecular \$

$\begin{array}{lcccclc}\text { Sample } & \text { Ab } & \text { An } & \text { Or } & \text { Cn } & \text { Feldspar } & \text { Crystal S1ze, } \mu m \\ \text { A2109 } & 51.5 & 45.7 & 2.8 & -- & \text { Andesine } & 75 \times 175 \\ A 2109 & 58.0 & 37.8 & 4.2 & -- & \text { Andesine } & 10 \times 80 \\ \text { A2109 } & 46.7 & 49.5 & 3.0 & -- & \text { Labradorite } & 100 \times 250 \\ \text { A2109 } & 49.4 & 47.6 & 3.0 & -- & \text { Aridesine } & 20 \times 75\end{array}$

Pyroxene-based on the unit cell $\left.\left[\left(\mathrm{K}, \mathrm{Ha}, \mathrm{Ca}, \mathrm{hl}, \mathrm{Fe}^{+2}, \mathrm{TH}, \mathrm{A}\right]\right)_{2}\right]\left[(\mathrm{Al}, \mathrm{SH})_{2}\right]_{6}$

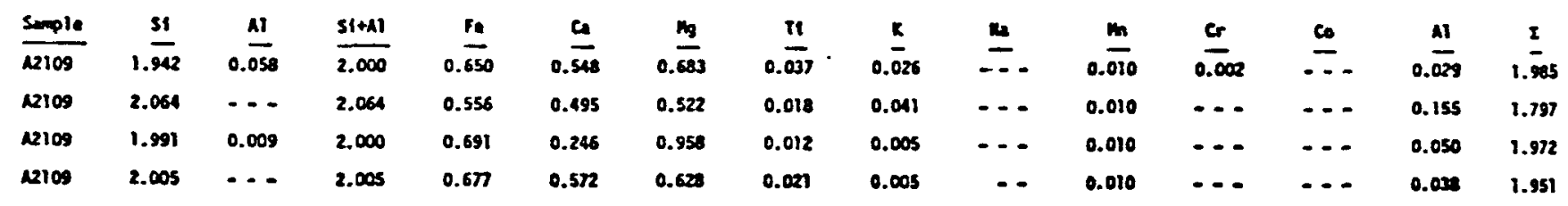

\begin{tabular}{|c|c|c|c|c|}
\hline \multirow[b]{2}{*}{ Sample } & \multicolumn{3}{|c|}{ Mole Percent } & \multirow{2}{*}{$\begin{array}{l}\text { Pyroxene } \\
\text { Identification }\end{array}$} \\
\hline & $\mathrm{MSIO}_{3}$ & $\underline{\mathrm{FeSIO}}_{3}$ & $\underline{\mathrm{CaSiO}}_{3}$ & \\
\hline 12109 & 36.3 & 34.6 & 29.1 & Augite \\
\hline A2109 & 33.2 & 35.3 & 31.5 & Ferroaugite \\
\hline A2109 & 50.6 & 36.4 & 13.0 & Intermediate Pigeonite \\
\hline A2109 & 33.5 & 36.0 & 30.5 & Ferroaugite \\
\hline
\end{tabular}

\begin{tabular}{|c|c|c|c|c|c|c|c|c|c|c|}
\hline \multicolumn{11}{|c|}{ Groundmass Composition Ht. $\%$} \\
\hline Sample & $\mathrm{StO}_{2}$ & $\mathrm{Al}_{2} \mathrm{O}_{3}$ & $\mathrm{Na}_{2} \mathrm{O}$ & $\underline{K}_{2} \underline{O}$ & Mgo & $\underline{\mathrm{CaO}}$ & eaO & Feo & $\mathrm{IIC}_{2}$ & wt.z \\
\hline A2109 & 47.6 & 11.7 & $\cdots$ & 4.3 & $\therefore$ & 2.6 & $\ldots$ & 23.4 & 8.0 & 98.7 \\
\hline A2109 & 72.6 & 12.5 & $\cdots$ & 8.5 & $\ldots$ & 1.4 & $\cdots$ & 1.8 & -- & 96.8 \\
\hline A2109 & 70.1 & 11.8 & $\cdots$ & 4.4 & $\cdots$ & 3.6 & $\cdots$ & 3.2 & 1.1 & 96.2 \\
\hline 12109 & 56.0 & 11.9 & 2.8 & 1.2 & 3.2 & 6.6 & $\cdots$ & 11.7 & 1.8 & 95.2 \\
\hline
\end{tabular}

Ho metallics found in sample 


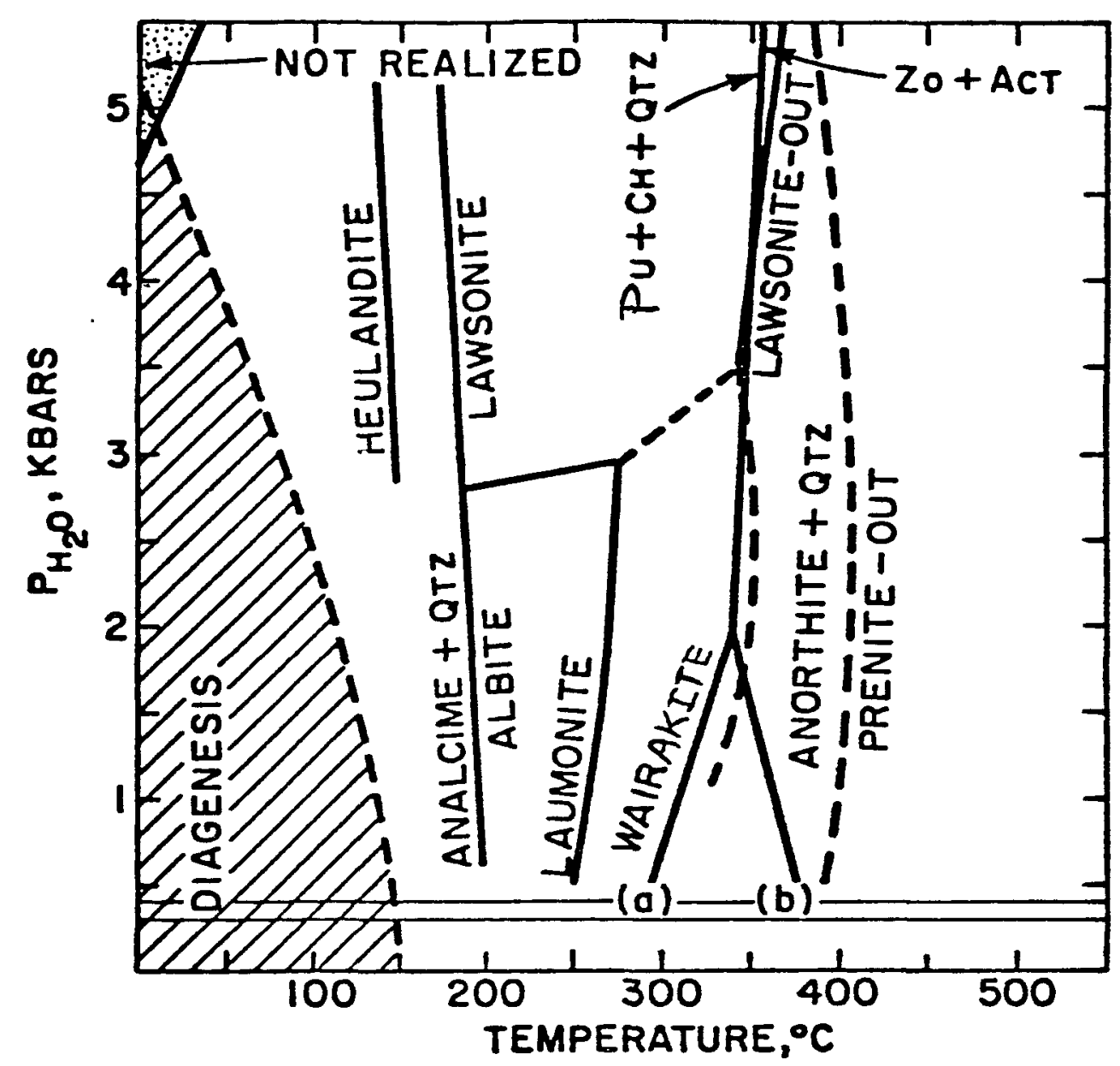

FIG. 4.1 Petrogenetic grid for low-grade metamorphism of mafic rocks (adapted from Winkler, 1976).

$$
\begin{aligned}
& \text { Act -- actinolite } \mathrm{Ca}_{2}(\mathrm{Mg}, \mathrm{Fe})_{5} \mathrm{Si}_{8} \mathrm{O}_{22}(\mathrm{OH})_{2} \\
& \text { albite } \quad \mathrm{NaAl} \mathrm{Si}_{3} \mathrm{O}_{8} \\
& \text { analcime } \quad \mathrm{NaAlSi}_{2} \mathrm{O}_{6} \cdot 2 \mathrm{H}_{2} \mathrm{O} \\
& \text { anorthite } \mathrm{CaAl}_{2} \mathrm{Si}_{2} \mathrm{O}_{8} \\
& \mathrm{Ch} \text {-- chlorite } \quad \mathrm{M}_{5-6}\left(\mathrm{Al} \mathrm{C}^{2}, \mathrm{Si}_{4} \mathrm{O}_{1 \mathrm{O}}(\mathrm{OH})_{8}\right. \\
& M=\mathrm{Mg}, \mathrm{Fe} \text { (II), } \mathrm{Ni}, \mathrm{Mn}, \mathrm{Al}, \mathrm{Fe} \text { (III) } \mathrm{Cr}, \mathrm{Li} \\
& \text { heulandite ( } \mathrm{Na}, \mathrm{Ca})_{4-6} \mathrm{Al}_{6}(\mathrm{Ai}, \mathrm{Si})_{4} \mathrm{Si}_{26} \mathrm{O} 72 \cdot 24 \mathrm{H}_{2} \mathrm{O} \\
& \text { laumontite } \mathrm{Ca}\left(\mathrm{Al}_{2} \mathrm{Si}_{4}\right)_{0} \mathrm{O}_{2} \cdot 4 \mathrm{H}_{2} \mathrm{O} \\
& \text { lawsonite } \mathrm{CaAl}_{2} \mathrm{Si}_{2} \mathrm{O}_{7}(\mathrm{OH})_{2} \cdot \mathrm{H}_{2} \mathrm{O} \\
& \text { prehnite } \mathrm{Ca}_{2} \mathrm{AT}_{2} \mathrm{Si}_{3} \mathrm{O} 10(\mathrm{OH})_{2} \\
& \mathrm{Pu} \text {-- pumpeliyite } \mathrm{Ca}_{2} \mathrm{MgAl}_{2}\left(\mathrm{~S}_{4}\right)\left(\mathrm{Si}_{2} \mathrm{O}_{7}\right)(\mathrm{OH})_{2} \cdot \mathrm{H}_{2} \mathrm{O} \\
& \text { Qtz -- quartz } \mathrm{SiO}_{2} \\
& \text { wairakite } \mathrm{Ca}\left(\AA_{1} \mathrm{Si}_{2} \mathrm{Si}_{4}\right) \mathrm{O}_{12} \cdot 2 \mathrm{H}_{2} \mathrm{O} \\
& \text { Zo -- zoisite } \mathrm{Ca}_{2} \mathrm{Al}_{3}\left(\mathrm{~S}_{3} \mathrm{O}_{12}\right)(\mathrm{OH})
\end{aligned}
$$


There is a vast literature on alterations of basalts (see for example, Coombs, et al., 1959 and Hyndman, 1972) and we have only begun to address it during the initial term of this contract. A diagram like Fig. 4.1 is not especially helpful for a basalt repository because the univariant curves do not usually extend down to the pressure range of interest and because it implies nothing about the rates of reactions. It does indicate that at moderate temperatures one major reaction under hydrothermal conditions could be the breakdown of plagioclase into zeolites or zeolites plus quartz. The specific minerals shown in Fig. 4.1 are end member compositions, whereas the zeolites resulting from the basalt plagioclase breakdown are likely to be more complex in composition; e.g., phillipsite, $\left(\mathrm{Ca}_{0.5}, \mathrm{Na}, \mathrm{K}\right)_{3} \mathrm{Al}_{3} \mathrm{Si}_{5}{ }^{\circ}{ }_{16} \cdot 16 \mathrm{H}_{2} \mathrm{O}$. In $\mathrm{FY} 1978$, we will be collaborating with geochemists at Lawrence Berkeley Laboratory who will be using thermodynamic modeling to provide further insights into mineral assemblages resulting from hydrothermal treatments. 


\subsection{Experimental Equipment and Procedures}

Because the research initiated in FY 1977 on waste-basalt interactions was the first of its kind, we will explain our experimental procedures and equipment with considerable detail in this section.

5.1 Dry-Low Pressure Experiments (Type A)

In order to examine the effects of "dry heat" on the waste forms, on the host rocks and on waste-basalt combinations under ambient conditions of water and oxygen partial pressures, $\mathrm{P}_{\mathrm{H}_{2} \mathrm{O}}$ and $\mathrm{pO}_{2}$, closed containers have been used. Silica glass was chosen because of its relatively low cost and ease of closure. Pellets of each of the three types of specimens (waste alone, rock alone or a 1:1 mixture of waste and basalt), were placed inside a silica glass ampul after first sealing one end and filling the bottom half of the ampul with a large mass of crushed basalt. We call this crushed material a "buffer" because it is designed to establish a more realistic $\mathrm{P}_{2} \mathrm{O}$ and $\mathrm{PO}_{2}$ during the lengthy heat treatments. The test specimen was kept away from contact with the buffer. It was necessary to pull a mild vacuum on the ampul in order to seal it by fusion in an oxyhydrogen torch. Care was taken to seal the tubes rapidly to prevent heating the rock buffer and thus minimize any loss of the natural moisture. Unquestionably, the vacuum treatment did cause the loss of some of the loosely bound water in the buffer. Note that in the sealed ampul there was a mild vacuum because, as we will point out in Section 6.0, these vacuum conditions seemed to enhance alkali volatilization with certain test specimens. The loading and sealing operation required approxinately 20 minutes per tube, which was relatively rapid as required by the large number of reconnaissance runs to be conducted.

After sealing, the silica glass ampules were placed in an asbestos sleeve. The sleeve prevented an implosion in one ampul from setting off failures in adjoining ampules. Heat treatment was carried out in ioutine Hoskins 5 -inch diameter crucible furnaces with temperature maintained by RFL Industries SCR solid-state controllers. There was room for all fourteen test specimens of a typical array in one furnace.

At the end of the heat treatment, the ampules were scored on a diamond saw and snapped open. 'The appearance of the ampul adjoining the specimen and of the buffer was noted in the run tables. 


\subsection{Hydrothermal Experiments (Types $C$ and D)}

The term "hydrothermal" as originally used referred to a reaction environment utilizing an aqueous medium at temperatures above the critical point of water $\left(373^{\circ} \mathrm{C}\right)$. The reaction medium was, therefore, a fluid rather than a gas or a liquid, but had a density comparable to that of a liquid. Many inorganic systems, including those whose components are extremely refractory, can. be induced to react to an equilibrium phase assemblage under these conditions. More recently, particularly in the materials field, "hydrothermal" has come to mean an experimental condition using any liquid for which pressure is required to prevent boiling at some elevated temperature. The more precise terms from the earth sciences, "epithermal" (near $100^{\circ} \mathrm{C}$ ) and "mesothermal" (between roughly $100^{\circ} \mathrm{C}$ and $373^{\circ} \mathrm{C}$ ), are seldom used.

During the 1960s, the Materials Research Laboratory (IRL) at The Pennsylvania State University was a leading center for materials preparation and crystal growth utilizing hydrothermal procedures. Our expertise was derived from some fifteen preceding years of hydrothermal experimental petrology and geochemistry research by E. F. Osborn, 0. F. Tuttle, R. Roy, D. M. Roy, W. B. White, and their students (Roy and Tuttle, 1956). However, the types of research performed at the MRL during the early 1970s generally involved little utilization of our hydrothermal facilities. Consequently, when the waste-basalt interactions program was initiated, it was first necessary to modernize and expand these facilities, and this constituted a substantial portion of our effort in FY 1977. Because many readers will be unfamiliar with hydrothermal facilities and procedures, we will describe these in some detail.

5.2.1 Equipment and Facilities. Two types of hydrothermal vessels are in use. Probably the most widely and most easily used type of hydrothermal apparatus is the cold seal vessel (sometimes called the "test tube 'bomb'") developed at the Geophysical Laboratory and Penn State in the late 1940s. Figure 5.1 shows the experimental configuration of the cold seal vessel and details of the cone seal. The vessel is made of stellite or René alloy and can be routinely operated at $900^{\circ} \mathrm{C}$ at 1,000 bars. Their expected lifetime is very long at the far lower P-T conditions of our wastebasalthydrothermal experiments. The great advantage of this pressure vessel 

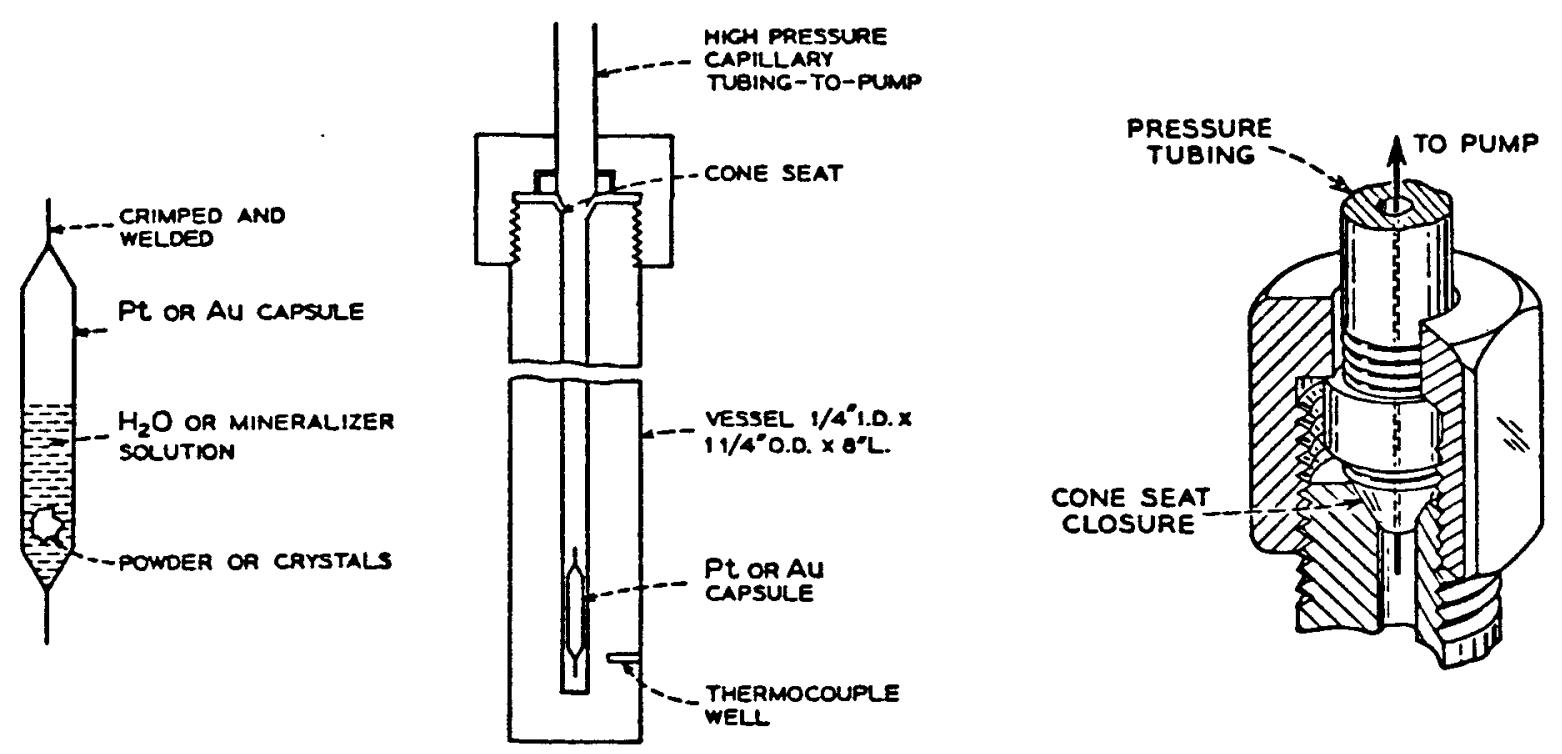

FIG. 5.1 Cold seal pressure vessel: (A) typical experimental configuration with gold capsules; (B) details of the cone seat closure. After Ballman and Laudise (1963) and Laudise (1970). 
is the accuracy with which temperature can be measured. Also, it can be handled and sealed effectively. The inner cone seals are easy to machine and inexpensive to replace. The disadvantage is in the small volume and, thus, the small number of gold capsules that can be run simultaneously in the vessels. The 0.25 -inch inside diameter (I.D.) vessels hold only one 5-mm gold capsule, while the 0.5-inch I.D. vessels hold about six.

Figures 5.2 and 5.3 show a typical rack of cold seal vessels and a floor plan of our largest cold seal laboratory. At the start of the year, only eight cold seal stations were operational. This number was increased to twenty-eight during the year through the efforts also of several other research programs which will utilize this type of equipment.

The second type of pressure vessel is the familiar autoclave illustrated in Fig. 5.4. Five autoclaves with volumes ranging from 200 to 600 ml have been put into use during FY 1977. The larger vessels will hold up to 100 individual $5-\mathrm{mm}$ sealed gold capsules and this constitutes their great advantage. The disadvantage is that they are quite cumbersome and difficult to seal properly. Because of the large volumes and thermal gradients, temperatures are less accurate with respect to any given capsule, compared to the cold seal vessels. They are constructed of a 400-series stainless steel and are fitted with a pressure gauge, a pressure valve and a blow-out safety valve. One of our assembled autoclaves is shown in Fig. 5.5 with the furnace along side. With the increased use of autoclaves this year, it was decided to build a heavy steel plate-plywnod safety enclosure. The autoclave laboratory floor plan is given in Fig. 5.6. Note that more autoclave stations are available if needed during the FY 1978 program.

The power supply-controllers are now almost all solid state. Temperatures are measured with chromel-alumel thermocouples and recorded on centrally wired digital readouts. It should be emphasized that the temperatures reported in Section 6 below are currently only external vessel temperatures. We are well aware that the actual internal temperatures in the cold seal vessels are typically $10-20^{\circ} \mathrm{C}$ lower (in the $200-400^{\circ} \mathrm{C}$ range) than the thermocouple well temperature (Boettcher and Kerrick, 1971) and in the autoclaves are probably lower still (by perhaps $50^{\circ} \mathrm{C}$ or more). We are currently constructing direct high-pressure, steel-sheathed, internal 


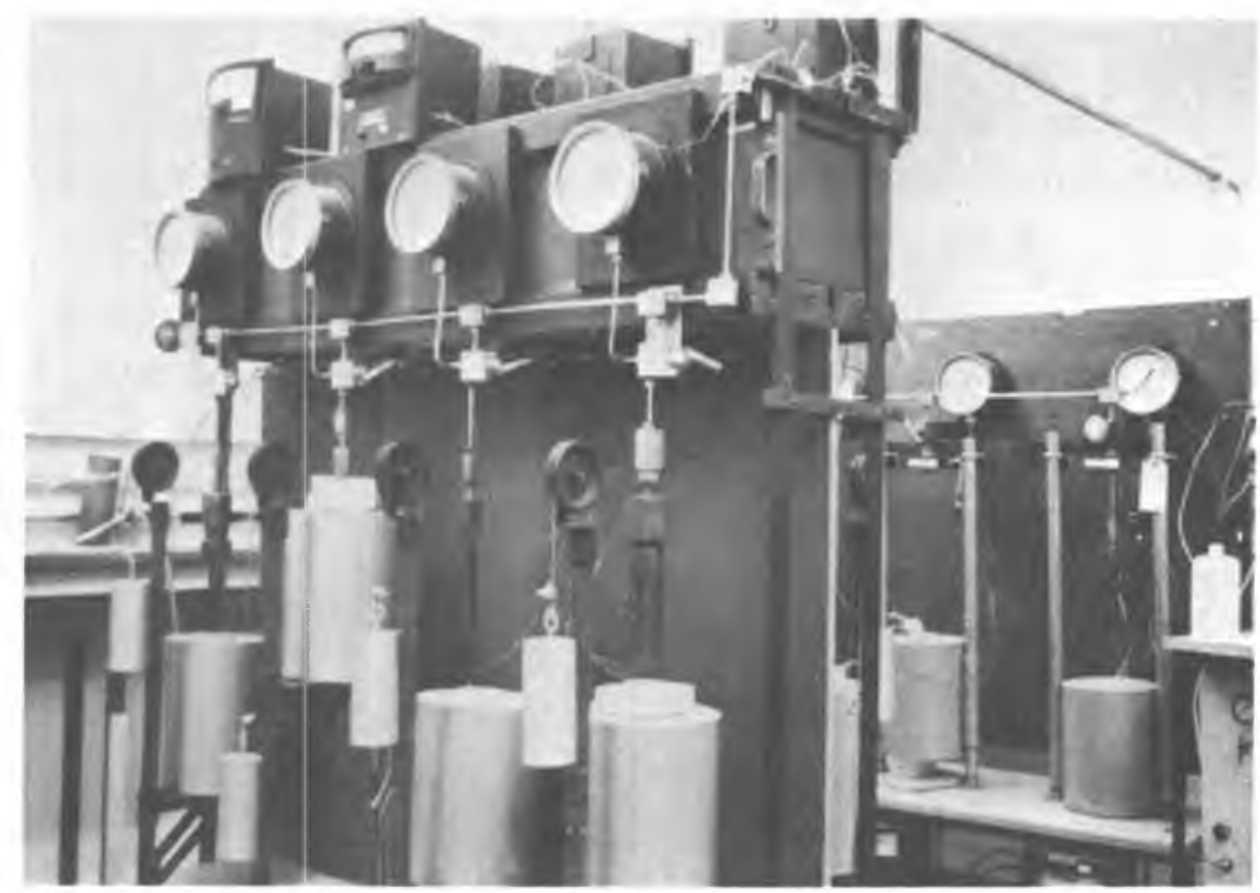

FIG. 5.2 Cold seal rack \#3. Both 0.25- and 0.5-inch inner diameter cold seal vessels are shown.

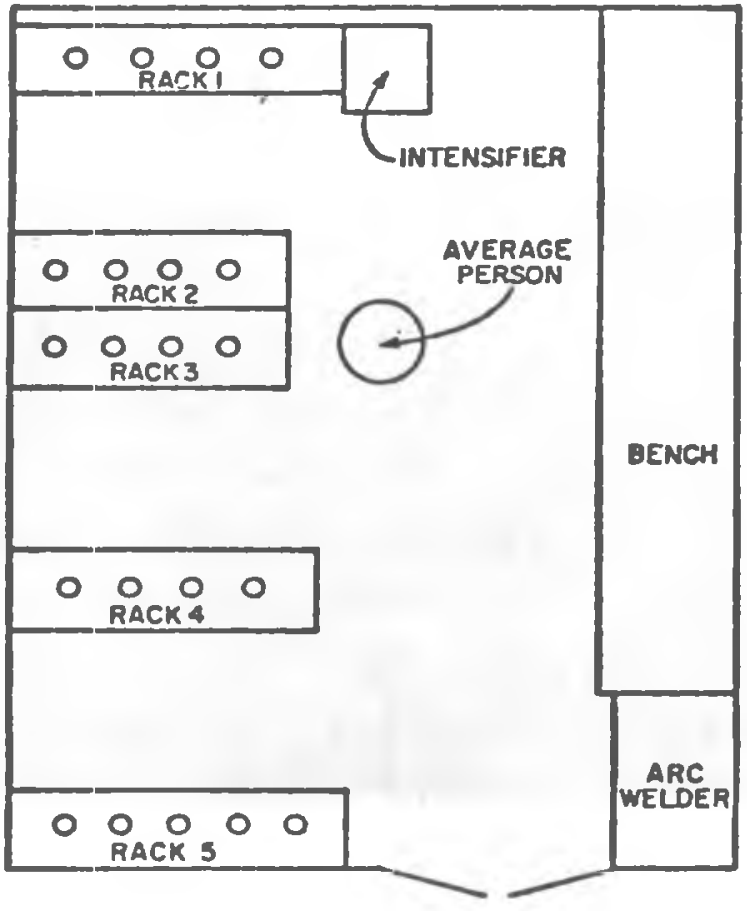

FIG. 5.3 The MRL cold seal hydrothermal laboratory. 


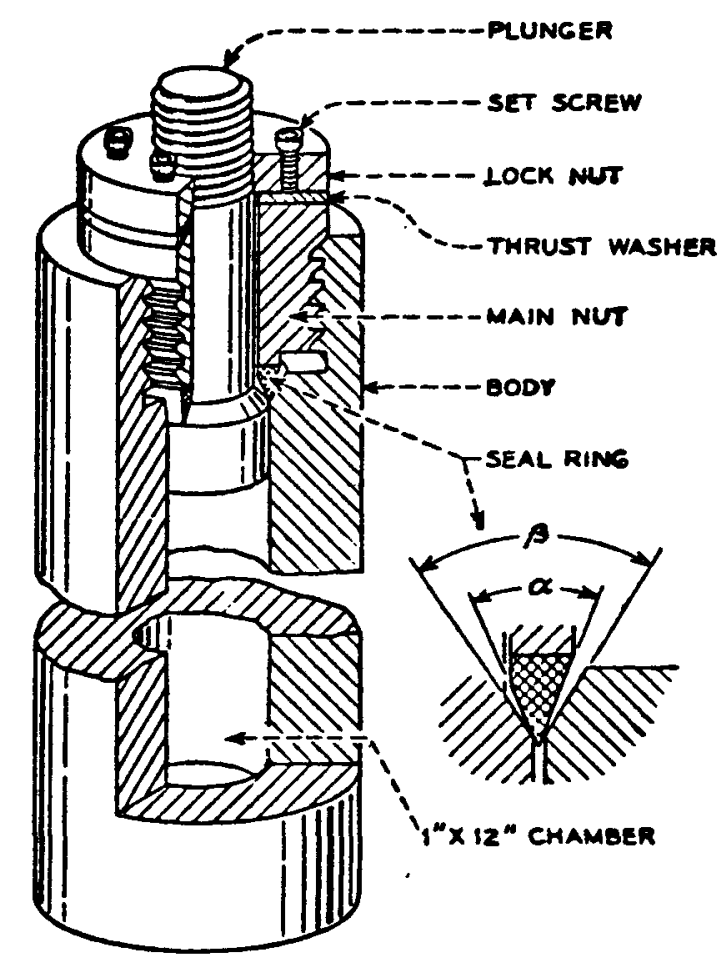

FIG. 5.4 Autoclave pressure vessel with a modified Bridgman closure [after Ballman and Laudise (1963)]. 


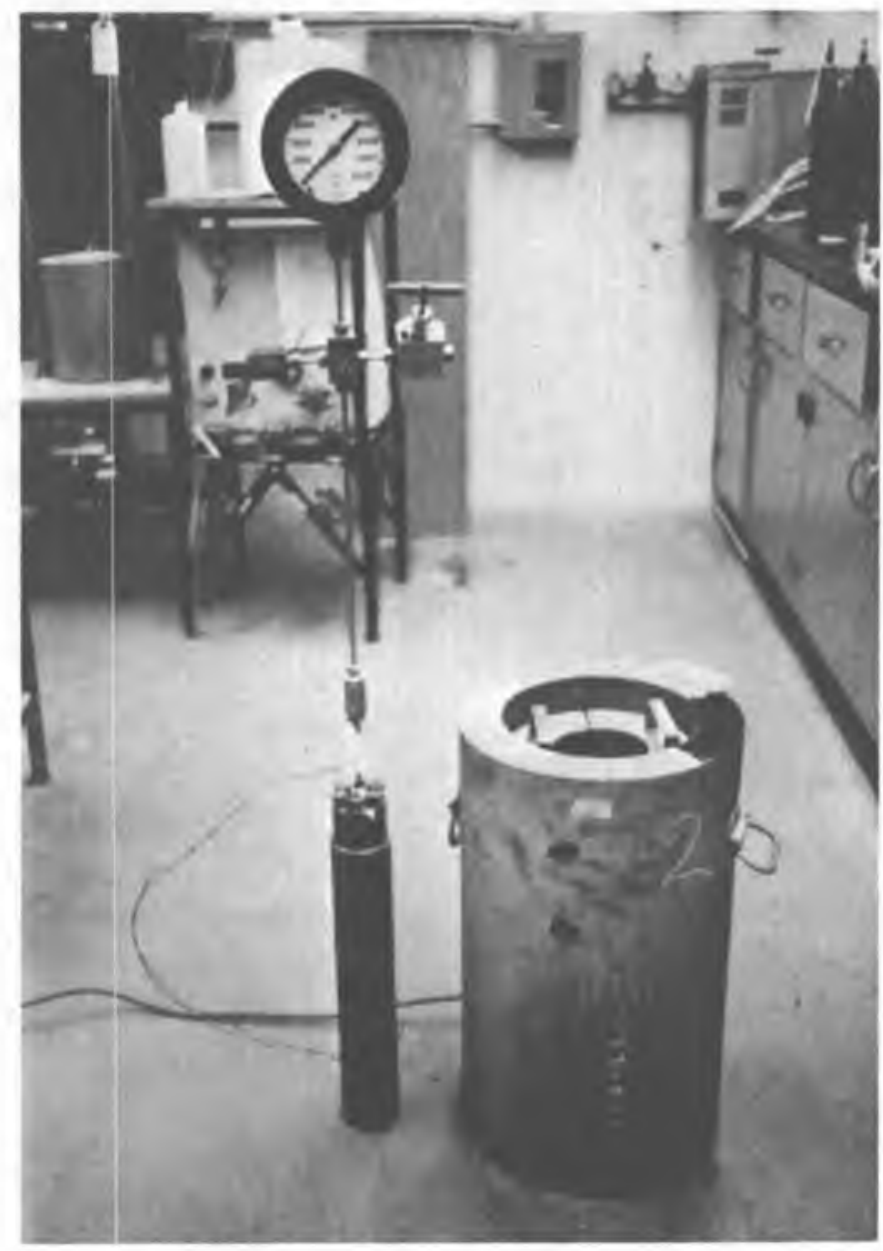

FIG. 5.5 Typical autoclave with pressure gauge, valve and blow-out valve attached. The autoclave furnace is to the right.

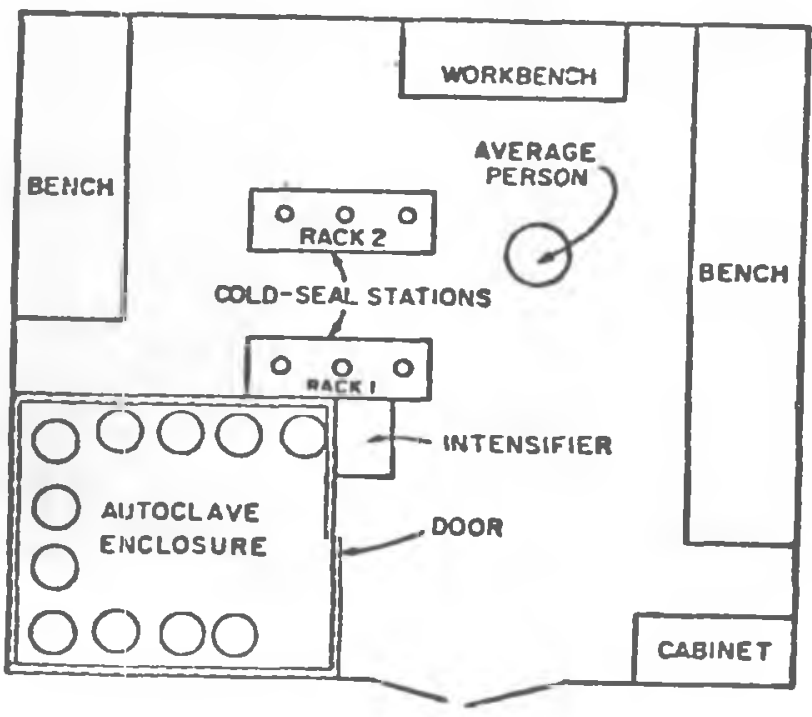

FIG. 5.6 The MRL autoclave laboratory. 
thermocouples for the autoclaves. It will be a relatively simple matter to obtain the correct values, instead of the nominal $200^{\circ} \mathrm{C}$ and $400^{\circ} \mathrm{C}$ temperatures listed in Section 6, with this apparatus in the near future. Of course, if it is found that the extensive hydrothermal reactions described in that section are actually occurring at $150^{\circ} \mathrm{C}$ rather than $200^{\circ} \mathrm{C}$, or at $340^{\circ} \mathrm{C}$ rather than $400^{\circ} \mathrm{C}$, then the significance of the reactions is all the greater.

Pressure is measured with a standard Bourdon gauge. Each hydrothermal vessel is pressurized by Sprague compressed air-driven hydraulic pumps. Water is used as the pressure medium. Six additional cold seal stations are equipped with high gas $\left(\mathrm{O}_{2}, \mathrm{~N}_{2}, \mathrm{CO}_{2}, \mathrm{Ar}\right.$, etc.) pressure intensifiers which could have application in later stages of the program.

\subsubsection{Experimental Procedures}

a. Preparation of Gold Tubes. The gold tubing is received from the manufacturer in odd lot lengths ranging from one to four feet long; while typical ampul lengths for the hydrothermal experiments are one-inch for type $C$ and 1-1/4 inches for type $D$ experiments. The as-received tubing is easily cut into the desired lengths by drawing a sharp razor blade across the tube and cutting it to a depth just enough to penetrate the wall of the cylinder. The cut length can be broken away from the remaining tube by taking the nicked tubing into your hands, nick away from the body, and applying steady pressure in a bending fashion. This procedure will ensure a clean break without collapsing the tubing. The process is identical to the procedure followed in cutting glass tubina.

The as-received tubing is work hardened and, to ensure a good seal, it must be thoroughly cleaned and annealed. The cut tubes are boiled in a 1:1 distilled water/HCl mixture for 20 minutes. They are rinsed well with distilled water and transferred, without handling, to a kyanite crucible and placed in a furnace and heated at $-700^{\circ} \mathrm{C}$. This heating cycle lasts two hours.

The gold tubes are sealed with an electric arc welder. First, one end of the tube is crimped shut either with the smooth jaws of a pliers or with a vise. The edge is trimmed with scissors to give a uniform surface for welding. Using a finely sharpened graphite electrode, an arc is drawn 
from one end of the crimp smoothly across the tube. The welding process is continually observed through a binocular microscope. A gold weld will have a shiny appearance and a uniform bead along the length of the welded area. This is aided by maintaining the arc welder at the lowest possible voltage-ampere settings. If discoloration occurs or if melted beads of gold produce large irregularities in the weld, the partially welded area is cut off and the process is repeated.

The tubes to be used in a given experiment are then marked with the run number and sample number. A scribe is used to scratch the run number and sample number onto the central portion of the tube.

The tube is weighed, charged with the appropriate amount of powder and reweighed. The mass of the powder is obtained by difference. The upper interior surface of the tube is cleaned with a pipe cleaner wetted with acetone and the appropriate quantity of water is added with a microsyringe.

The final sealing step is accomplished by carefully crimping the open end of the tube and trimming with a scissors. This crimped end is then placed in the welding vise and securely tightened into place. It is important at this point to have good thermal contact established between the gold tube and the vise which will act as a heat sink. To ensure immobilization of the water, the tube can be placed in contact with a piece of dry ice to solidify the water. The second weld is accomplished as previously described.

The most critical step in any long-term hydrothermal experiment is to ensure that the integrity of the ampul will be maintained for the duration of the experimental run. Faulty welds can be detected by immersing the gold ampul, while holding it with tweezers, into a beaker of water just below its boiling point. Entrapped air will rapidly expand and a bubble stream will indicate the location of che leak. An alternative procedure that is followed by some laboratories is to squeeze the ampul between the thumb and forefinger. The hydrostatic pressure inside of the ampul will rise and a jet of fluid will locate the faulty weld. This procedure has not been followed in our research. The net weight of the gold tube, solid charge and fluid is obtained and the ampul is placed into a vacuum drying 
oven and heated between $90^{\circ}-95^{\circ} \mathrm{C}$ at $\sim 1$ torr pressure. These are typically left overnight and reweighed the next morning. If there is a change of $0.1 \%$ or greater in the weight of the sealed ampul, the vacuum heating procedure is repeated to see if there is a continued weight loss. If it continues to lose weight, the sample is replaced.

The entire set of individual runs is wrapped in a stainless steel net and tied with platinum wire in preparation for placement into the autoclave.

b. Autoclave Assembly Techniques. The most important step in ensuring a good seal with the modified Bridgman vessels is to have polished seals and sealing surfaces. Cleaning the inside of the vessel and polishing these seals and sealing surfaces of the vessels is done as routine maintenance of the autoclave.

The following are the detailed procedures used for experiments involving the autoclaves:

1. Using appropriate pressure and temperature for the run, refer Kennedy's table of "Pressure, Volume and Temperature Relations in Water" and add the appropriate percent fill of water to the vessel.

2. Place samples in vessel.

3. Place seal ring on plunger, screw plunger onto main nut, place thrust washer on top followed by lock nut. Coat threads of main nut with graphite lubricant.

4. Screw this apparatus into body of vessel.

5. Tighten the main nut by inserting rod into the holes of the main nut and tighten. Coat threads of all set screws with graphite lubricant.

6. Loosen assembled set screws.

7. Tighten all set screws finger tight.

8. Using a torque wrench, tighten one set screw to 20 foot-pounds. Then tighten the opposing set screw to 20 foot-pounds. Continue until all set screws have bet 1 tightened to 20 foot-pounds.

9. Repeat step 8 , tightening all set screws to 40 foot-pounds.

10. Attach pressure gauge, rupture disc and release valve to top of plunger. With a wrench, tighten gland on rigid tubing securely to plunger.

11. Attach two thermocouples to the exterior of the autoclave at the same level as the samples. 
c. Startup of a Run.

1. Attach one thermocouple to the temperature controller and one to the temperature readout (attach on the autoclave in vicinity of charge).

2. Place in furnace and heat up to desired temperature.

3. Watch the pressure in the vessel carefully until internal temperature equilibrium is reached. Adjust pressure by bleeding system off or by intensifying as necessary. All runs should be started early in the morning to ensure that equilibrium is reached before personnel leave.

4. Monitor temperature and pressure daily.

5. To terminate run: (a) turn off controller, (b) unplug controller, (c) very carefully lift vessel out of furnace and allow to air cool (do not release pressure).

d. Autoclave Disassembly Techniques.

1. Check bleed valve to be sure there is no pressure remaining in vessel.

2. Place vessel tightly in vise.

3. Loosen a set screw to twenty foot-pounds. Then loosen the opposing set screw to twenty foot-pounds. Continue until all set screws have been loosened to twenty foot-pounds.

4. Repeat step 3, removing all set screws but one.

5. Loosen gland that attaches gauge and rupture disc to vessel and remove.

6. Loosen main nut and remove.

7. Remove gold tubes, rinse in distilled water and let dry.

8. Weigh tubes using the same technique as before firing. If any ampules show loss or gain greater than one milligram, place it in vacuum drying oven following the procedure in part (a) and check for weight losses. 


\subsection{Characterization}

5.3.1 Optical Microscopy. A procedure has been established to evaluate the reaction products as a means of obtaining a first-cut classification of alteration in waste-basalt experiments. This procedure utilizes the advantages of a low-power binocular microscope, a petrographic microscope, and, occasionally, a reflecting light microscope.

The initial jurvey of experimental runs is performed with a Nikon stereoscopic zoom binocular microscope. The objective lens is infinitely variable between a magnification of $0.8 x$ to $4.0 x$. This, coupled with a pair of 20X oculars, gives an effective working range of maqnification of $16 x$ to $80 x$.

The surface of the specimen and the interior surface of the noble metal ampul are carefully examined for indications of crystal growth or grain growth. Changes in body color, incrustations or development of unusual colorations are usually associated with chemical alteration. Where it is possible, the charge from the ampul is broken apart and the interior of the sample is examined for the above changes.

Grain mounts or hand-picked crystals are examined in oil with a standard Zeiss transmitted light microscope that is equipped with a polarizer and analyzer, a condensor and substage, a rotary stage, and a Bertrand lens. The objective turret mounts four objectives, 2.5X, 10X, $25 \mathrm{X}$, and 50X. The ocular lense is $18 \mathrm{X}$, thus providing a working range of magnification of $45 X$ to $900 X$.

Samples are examined in plane polarized light to observe any pleochroism and to determine the relative refractive index by the method of Becke lines. Observation under crossed Nicols will separate the phases into isotropic or non-isotropic systems. With the microscope set up as a conoscope, and with the use of the appropriate accessories (gips plate, 1/4 wave plate, or quartz wedge), the non-isotropic crystals can be separated into uniaxial or biaxial systems and the optic signs determined.

In the coming year, we will be studying interactions of more massive specimens of starting materials under hydrothermal conditions. Under these circumstances, the piece can be mounted in cold mount and polished to an optical finish. Samples of this type will be examined in a Leitz 
reflecting light microscope equipped with dark field illumination. This arrangement will enhance the constrast between intimately mixed phases or opaques based upon the intrinsic differences in the reflectivity of the mineral phases.

\subsubsection{X-ray Powder Diffraction. In addition to optical} microscopy, this technique is essential in the rapid identification of interactions involving crystalline materials. It is clearly a bulk analysis tool because it is only sensitive to phase changes involving 2-10 wt $\%$ (the exact value depends primarily on X-ray absorption characteristics) of the specimen. During the initial phase of the program, we have used XRD only in a screening mode. During the coming year, we will employ XRD for complete phase analyses in model systems, for probing solid solution substitution by unit cell parameter determination and for identification of individual small crystals $(20-100 \mu \mathrm{m})$ formed under hydrothermal conditions. A Gandolfi powder camera will be used for this last function.

Two diffractometers are used for the screening characterization. They are both equipped with constant potential generators, $\mathrm{Cu}$ radiation, graphite diffracted beam monochromators, scintillation detectors, solidstate electronics and strip chart recorders. Diffractograms (strip chart tracings) are obtained for each specimen before and after treatment. Visual comparisons indicate whether there have been any changes in phase behavior (crystallization, recrystallization, amorphization or formation of new phase assemblaces). Identification of unknown phases is performed with the manual and computer indexes to the JCPDS Powder Diffraction File (PDF). We have found the Mineral Subfile of the PDF to be especially helpful in phase identification.

\subsubsection{Scanning Electron Microscopy . The advantage of using} SEM techniques are large depth of focus, easy sample preparation, high resolution, qualitative elemental anilysis on as-reacted specimens and quantitative chemical analysis for flat polished specimens.

The system employed includes a JOELCO 50A SEM with the appropriate interface to a Digital PDP $11 / 20$ computer. The system is capable of analyzing signals generated, by secondary electrons (SE), back-scatter electrons, (BS) and the characteristic X-ray energy (EDX) of individual elements with 
atomic number greater than neon. The maximum working magnification using a CRT and the SE signal is $30,000 x$; however, the practical maximum magnification when coupled with the EDX capability is limited to about 3,000X. Qualitative elemental compositon determination using EOX requires that the sample be mounted on a substrate, usually graphite, and coated with an evaporated film of carbon. Elemental identification based on characteristic $X$-ray emission is generally straightforward. However, in a few cases; i.e.. $\mathrm{Na}$ and $\mathrm{Zn}$, where the strong $L_{B}$ emission of zinc overlaps the $K_{\alpha}$ emission of sodium, an unambiguous identification of the element is difficult. The separation of individual close-lying energies is limited by the $164 \mathrm{eV}$ resolution of the Kevex EDX system employed with the SEM.

The SEM system offers several other capabilities that have not as yet been utilized. These include quantitative chemical analysis with the aid of standards and on-line computation facilities. In addition, the wellknown routine for Computer Evaluation of Scanning Electron ilicroscope Images (CESEMI), originally developed in our laboratory, has the capability of obtaining average particle size, qualitative and quantitative chemistry and an aspect ratio for both powder dispersions and bulk multiphase specimens. 


\subsection{Preliminary Results and Discussion of the Reconnaissance Experiments}

As noted earlier, the bulk of our effort in FY 1977 was directed toward refurbishing and updating equipment and developing experimental procedures. Nevertheless, some 128 reconnaissance experiments were performed. In this section, we will describe the brief survey characterization which was carried out for most of the run products in the last month of the FY 1977 program. This description will give the reader an overview of the kind of waste-basalt interactions that occurred, but we must state at the outset that any interpretations should be considered as preliminary. The reader should contact the principal investigator for the most up-to-date interpretation before citing data interpretation from this section.

Run tables containing the optical microscope and $X$-ray diffraction observations completed to date are appended to this report as Appendix $B$.

\subsection{Dry-Low Pressure Experiments (Type A)}

Run Tables 1-10 list the optical and $X$-ray observations of the 58 runs of this type. Heat treatments were performed at the following temperatures and times.

$\begin{array}{ll}200^{\circ} \mathrm{C} & 42 \text { days } \\ 400^{\circ} \mathrm{C} & 30 \text { days } \\ 600^{\circ} \mathrm{C} & 14 \text { days } \\ 600^{\circ} \mathrm{C} & 30 \text { days }\end{array}$

The highest temperature, $600^{\circ} \mathrm{C}$, was somewhat greater than any current projections for even the early thermal period. But, because little solid-state reaction was expected at the lower temperatures, it was of interest to determine whether any would occur at this higher temperature. The conditions of the experiment were in the "accelerated" mode because the specimens of waste and rock were ground to -200 mesh and intimately mixed. If no interactions were observed with this configuration, then it should be unnecessary to proceed to more massive specimens that make minimal direct contact.

In each of the heat treatments, the expected result was generally obtained; namely, no obviois changes or interactions in the test specimens. 
One notable observation was the frosting or devitrification of the originally clear silica glass, especially for runs made with the waste having the highest alkali concentration. (PW-7a calcine). In the $400^{\circ} \mathrm{C}$ and $600^{\circ} \mathrm{C}$ runs of pure PW-7a, the ampules were so severely attacked that they imploded. Where PW-7a was mixed with the basalts, the ampules held, but were the most heavily frosted. The alkali (especially $\mathrm{Na}$ ) vapor pressure must be reasonably high and the silica glass appears to be a sensitive indicator of this mobile alkali.* This would seem to imply that if calcine were the waste form and the canister were somehow to develop a crack or leak, some alkali ( $\mathrm{Na}, \mathrm{Cs}, \mathrm{Rb}$ ) might be mobilized by vaporization during the early thermal period when the temperatures are highest. However, it should be remembered that mild vacuum conditions were maintained in the ampules during the run (the ampules gave an audible "pop" when snapped open) and, thus, should have greatly accelerated the alkali vaporization and transport. We are currently testing each of the four waste forms in an open silica glass capsule to see whether this phenomenon will be observed at one atmosphere of pressure.

A scan of the optical microscope observations section of the run tables of the $200^{\circ} \mathrm{C}$ and $400^{\circ} \mathrm{C}$ heat treatments will indicate that there were no obvious interactions between, or changes in, the wastes, the basalts, and the waste-basalt mixtures. One exception was changes in the color of the test specimens in several cases. We attribute this to changes in oxidation state due to equilibration with the $\mathrm{PO}_{2}$ prevailing in the sealed ampul as established by the large excess of crushed basalt. Color changes were also occasionally noted in the top few millimeters of this basalt buffer; so, we believe that this feature of our dry-low pressure experiments is important to proper simulation of repository ambients.

After the $600^{\circ} \mathrm{C}$ heat treatments, specimens containing $\mathrm{PW}-7 \mathrm{a}$ calcine and 76-68 glass waste forms did show some evidence of interactions. White crystal growths were noted on several of the pellet surfaces.

*McCarthy and co-workers used this frosting of silica glass to detect trace levels of alkali volatilization from developmental supercalcine formulations. 
Figure 6.1 shows an SEM photomicrograph and the EDX chemistry of the surface of a pellet consisting of a 1:1 mixture of $\mathrm{PW}-7 \mathrm{a} / \mathrm{BCR}-1$ heated at $600^{\circ} \mathrm{C}$ for 4 weeks. The $30 \mu \mathrm{m}$ crystals of platelet morphology have an EDX chemistry of $\mathrm{Na}, \mathrm{Al}, \mathrm{Si}, \mathrm{Mo}, \mathrm{K}$ and $\mathrm{Fe}$. One possible mineral phase consistent with this chemistry is a $\left(\mathrm{MoO}_{4}\right)$ analog of the sodalite phase nosean:

$$
(\mathrm{Na}, \mathrm{K})_{8}(\mathrm{Al}, \mathrm{Fe})_{6} \mathrm{Si}_{6} \mathrm{O}_{24}\left(\mathrm{MoO}_{4}\right) \text {. }
$$

However, the symmetry of nosean is cubic and, therefore, not consistent with the platy habit.

Dry heating of PW-7a calcine and DDH-3 basalt (Run 25-F-4) at $600^{\circ} \mathrm{C}$ for four weeks also yielded some interaction. Tiree morphologically distinct crystal types were observed by SEM:

- Platelets $-25 \mu \mathrm{m}$ in maximum dimension (EDX chemistry, $\mathrm{Na}, \mathrm{Si}, \mathrm{Al}$, $\mathrm{K}, \mathrm{Fe}$, and $\mathrm{Mo}$ );

- Fine needle crystals $-5 \mu \mathrm{m}$ long (EDX chemistry, Na, Si, K, Ca, Ti and $\mathrm{Fe}$ ); and,

- Euhedral aggregates $-25 \mu \mathrm{m}$ in diameter (EDX chemistry, Si) (polymorph of $\mathrm{SiO}_{2}$ ?).

The platelets formed in this experiment are similar in appearance and chemistry to those described above for Run 25-A-4.

At $600^{\circ} \mathrm{C}$ the specimens of $76-68$ glass alone showed the effects of softening and had sintered into a vitreous mass. A white coating on the surface was noted. By SEM, this coating consisted of equant, euhedral crystals that reached $\sim 75 \mu \mathrm{m}$ in maximum dimension and needle crystals with dimensions of $0.1 \mu \mathrm{m} \times 40 \mu \mathrm{m}$; infrequently these were found as spherulitic aggregates. EDX chemistry for all of these morphologies indicated the presence of only $\mathrm{Si}$, presumably as a polymorphic form of $\mathrm{SiO}_{2}$.

Little time was available for detailed analysis of the X-ray diffractograms. In the $x$-ray observations section of the run tables, we have noted unly whether there was any appreciable change in the diffractograms of the specimens before and after the heat treatments. Significant changes in the relative intensities of peaks were also noted. It should be noted again that XRD would generally be sensitive to interactions involving -5 weight $\%$ or more of the bulk of test specimen. 


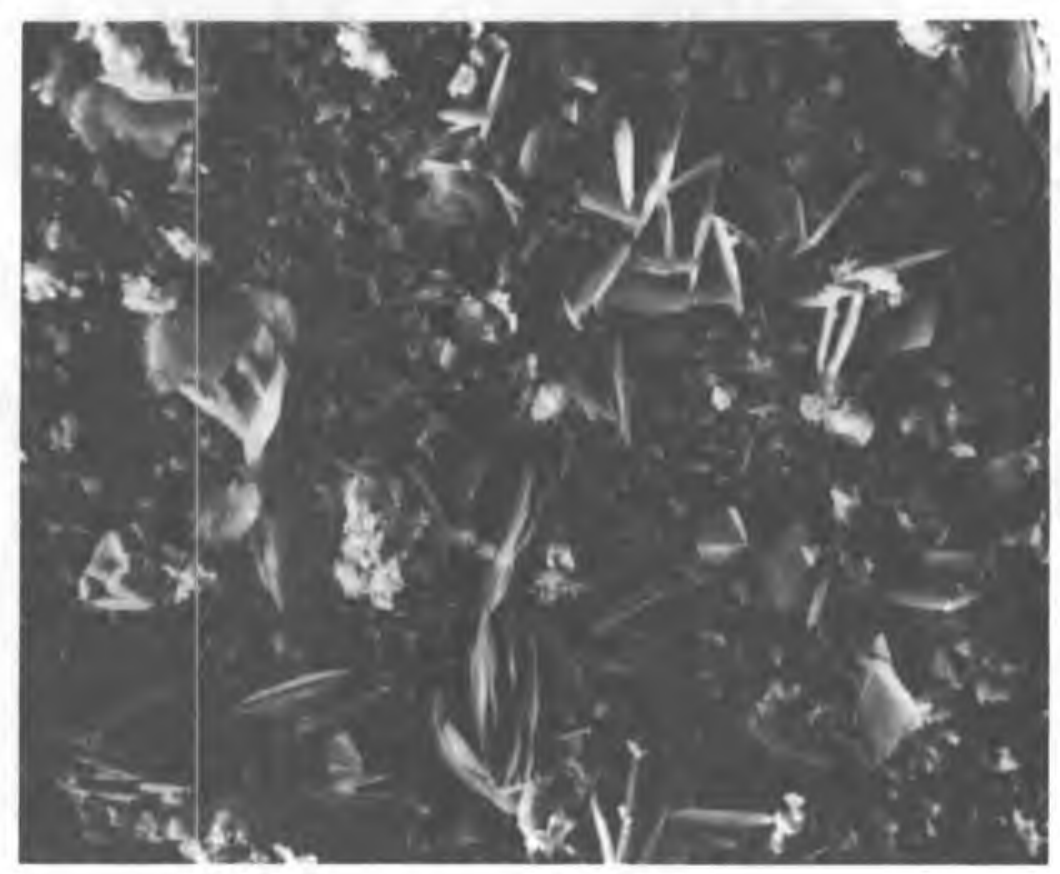

(a) Surface of Run 25-A-4. Plateletes are $\sim 30 \mu \mathrm{m}$ in the long direction.

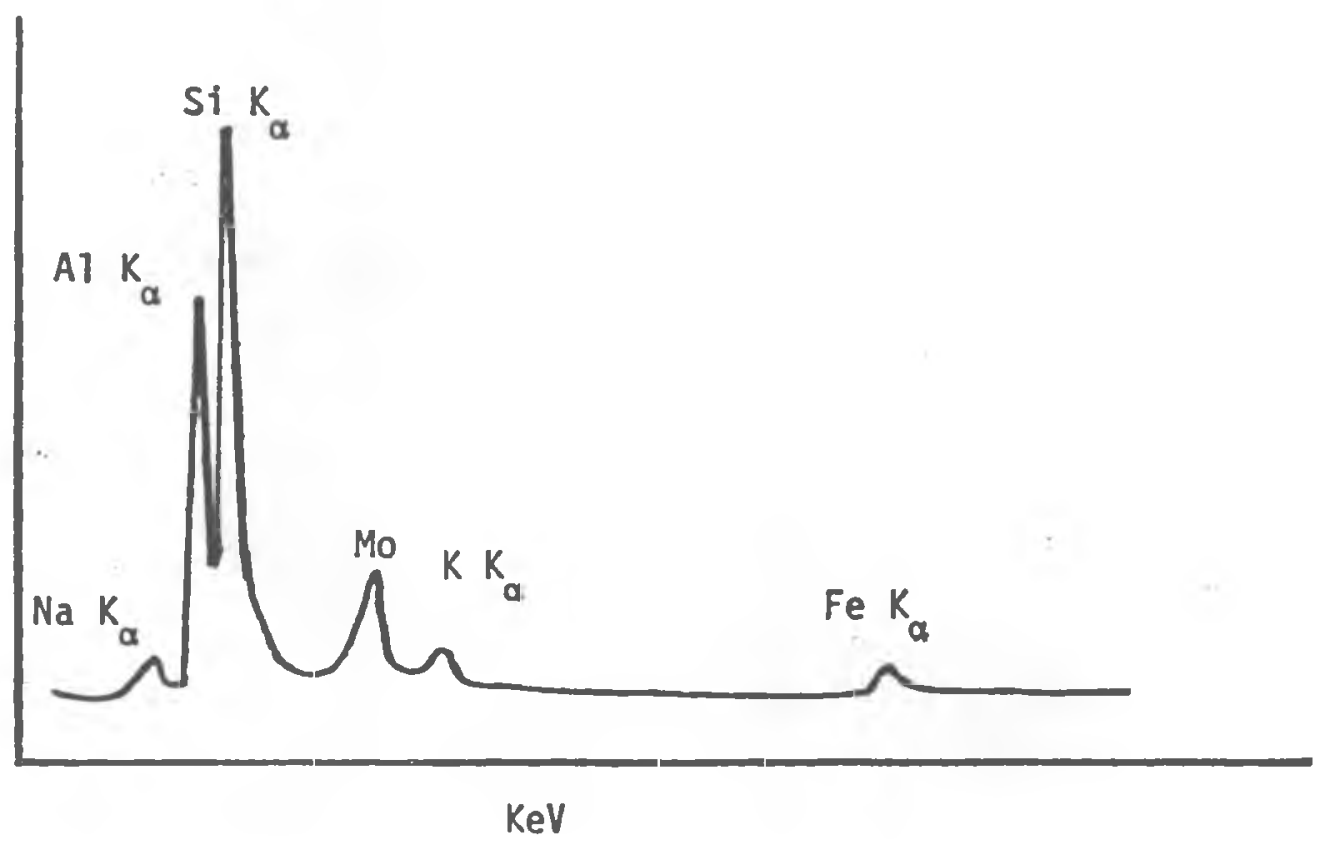

(b) EDX chemistry for crystals from Run 25-A-4.

FIG. 6.1 
Less time was spent looking at run products where spent unreprocessed fuel and supercalcine were the waste forms. Aside from slight changes in color in the spent unreprocessed fuel (due probably to $\mathrm{P}_{\mathrm{O}_{2}}$ equilibration with the basalt buffer), no evidence has been noted as yet for interactions involving these more inert waste forms. Note that the frosting of the silica glass occurred even in spent unreprocessed fuel runs where the total alkali ( $R \mathrm{~b}$ and $\mathrm{Cs}$ from the fission products) content was $<<1$ weight $\%$.

Discussion and Summary. In general, very little, if any, changes or interactions occurred in the lengthy $200^{\circ} \mathrm{C}$ and $400^{\circ} \mathrm{C}$ heat treatments. Evidence of alkali volatilization was present, but it is not yet known whether this was due to ihe partial vacuum environment in the ampul and the strong affinity of silica glass for interaction with alkali vapors. At $600^{\circ} \mathrm{C}$, there was evidence for the beginnings of interactions, but, here again, the crystal morphologies observed by SEM are typical of vapor growth under vacuum conditions. We believe that several high-temperature experiments involving calcine and glass waste forms should be repeated in a more inert container and for very long times (months to years) in order to further assess the potential for alkali (especially Cs) transport via vaporization. Sealed gold capsules could be used, but both the cost and complexity of each run would be far greater than those described above. The experimental configuration with the large excess of a basalt buffer physically separate from the specimen should be retained. However, because of the mandate to syend 80\% of our time in FY 1978 on SURF-related experiments, work on type $A$ runs involving calcine and glass will necessarily have the lowest priority in the near future.

\subsection{Hydrothermal Experiments (Types C and D)}

The experiments performed under combined elevated pressures and temperatures will be discussed together in this section. "Type C" indicates the use of only a small amount of extra water ( 2 wt \% of the test specimen weight) and "type D," a substantial amount of water (50 wt \% of the test specimen weight). The first runs of these types were actually initiated in April 1977. However, there was a high percentage of failures due to inexperience by the technician with arc welding the gold 
capsules and on effective closure of the autoclaves. When it was found that many of the welds had not held during the lengthy hydrothermal treatments, elaborate testing of the capsules for leaks before starting a run was instituted (see Section 5.2.2) and this resulted in a dramatic reduction in leaks discovered only after the investment of 30 or more days in a run. The second problem is particularly insidious, because, when an autoclave containing up to 60 separate capsules loses pressure while at temperature, those capsules containing the type $D$ (high water) experiments usually fail. After several of these failures in pressure-sealing the autoclaves, we initiated the high-pressure testing of the sealed autoclaves before heating was started. If the autoclave did not hold the required pressure for several hours, it was depressurized and the sealing surfaces were cleaned before resealing.

In Section 6.2 we will describe 70 hydrothermal runs made during July, August and September 1977. Only 16 of these leaked. The results of the optical and X-ray characterization performed to date are collected according to the run conditions in the following run tables in Appendix $B$.

$\begin{array}{ll}\text { Run Tables } 11-13 & 200^{\circ} \mathrm{C} / 325 \text { bars / } 30 \text { days / type C } \\ \text { Run Tables } 17-19 & 200^{\circ} \mathrm{C} / 275 \text { bars / 30 days / type D } \\ \text { Run Tables } 14-16 & 400^{\circ} \mathrm{C} / 275 \text { bars / 30 days / type C } \\ \text { Run Tables } 20-22 & 400^{\circ} \mathrm{C} / 275 \text { bars / } 30 \text { days / type D }\end{array}$

Pressures for the first groups of experiments performed during the early part of the FY 1977 program were set at approximately 6,000 psi ( 400 bars), but were lowered to -300 bars after discussions with M. W. Grutzeck at Penn State in July. He do not believe that differences of pressure of this amount will substantially affect most hydrothermal reactions and interactions. Run Tables 24 - 30 are for one of the earlier sets of experiments in which only 8 of 30 gold capsules remained sealed. They have been included because a substantial amount of characterization was performed on them while we awaited the completion of the later sets of runs. Note, however, that open system conditions prevailed for most of these runs.

Because of the shortage of time near the end of the contract period, SEM characterization was confined to runs containing either calcine PW-7a or glass $76-68$ as it was with these experiments that the 
greatest and most obvious interactions had occurred. SEM characterization of runs containing SURF will be emphasized in the fall of 1977.

6.2.1. Hydrothermal Treatment of Waste Forms. Interspersed throughout Run Tables 11 - 30 are experiments in which only the waste forms have received hydrothermal treatments. An overview shows that calcine and glass reacted with, and were partially dissolved by, water with the accompanying growth of crystalline phases made up of elements from the glass and which were probably closer to equilibrium in the $\mathrm{P}_{\mathrm{H}_{2} \mathrm{O}} \mathrm{T}$ conditions of the run. The level of interaction was far greater with type $D$ than with type $C$ experiments as expected. Supercalcine 76-2 also showed some effects of hydrothermal treatment, but in this case the effects were simply enhancement of the crystallinity of several of its nine constituent phases, especially of pollucite, $\mathrm{CsAlSi}_{2} \mathrm{O}_{6}$, a natural hydrothermal mineral. Similarly, optical microscopic observation indicated little reaction between SURF and Hanford ground water.

A number of hydrothermal runs not listed in the run tables were made with glass 76-68. The conditions of seven of these runs and some optical and X-ray observations are given in Table 6.1. Runs $J H-1,-2$, and -3 were made to see whether interactions and changes in phase behavior would occur in a period as short as 64 hours (over a weekend) instead of the one month being used for the large matrices of reconnaissance runs. The X-ray diffractograms of the products (see Figure 6.2) indicated extensive conversion to crystalline phases in the $400^{\circ} \mathrm{C}$ run and to a lesser extent in the $600^{\circ} \mathrm{C}$ run. The diffractogram of this 2.6 -day $400^{\circ} \mathrm{C}$ run was remarkably like that of the corresponding 30 -day $400^{\circ} \mathrm{C}$ run ( $10 \mathrm{R}-\mathrm{L}$, Run Table 22) suggesting that the hydrothermal attack on the glass to form a new crystalline phase assembiage may occur quite rapidly and a steady-state phase assemblage may be established within a few days.

SEM characterization has been performed on a number of the hydrothermal treatments of glass 76-68 listed in Table 6.1 in an effort to identify the crystalline phases formed by the breakdown of the glass. Figures 6.3 and 6.4 show the surface of the sintered product resulting from run $17 .-8\left(400^{\circ} \mathrm{C}, 400\right.$ bars, 30 days, Hanford ground water, gold capsule leaked). Two crystal morphologies are observed: 
TABLE 6.1

Hydrothermal Experiments with Glass 76-68.

\begin{tabular}{|c|c|c|c|}
\hline Code & $\begin{array}{l}\text { Run } \\
\text { Conditions }\end{array}$ & $\begin{array}{l}\text { Optical } \\
\text { Microscopic Observations }\end{array}$ & $\begin{array}{l}\text { X-ray } \\
\text { Observations }\end{array}$ \\
\hline JH-1 & $\begin{array}{l}200^{\circ} \mathrm{C} \\
400 \text { bars } \\
64 \text { hrs } \\
\text { Type D }\end{array}$ & $\begin{array}{l}\text { green-yellow crust along walls of gold } \\
\text { capsule; some "cementing" of powdered } \\
\text { glass specimen; some bright, yellow } \\
\text { grains throughout specimen }\end{array}$ & $\begin{array}{l}\text { no significant } \\
\text { change }\end{array}$ \\
\hline $\mathrm{JH}-2$ & $\begin{array}{l}400^{\circ} \mathrm{C} \\
400 \text { bars } \\
64 \text { hrs } \\
\text { Type D }\end{array}$ & $\begin{array}{l}\text { more sintering of powdered glass; dark- } \\
\text { er color than } \mathrm{JH}-2 \text {; black, yellow and } \\
\text { white grains; milky white crystals on } \\
\text { surface of the specimen }\end{array}$ & $\begin{array}{l}\text { significant crys- } \\
\text { tallization or } \\
\text { dissolution and } \\
\text { recrystalliza- } \\
\text { tion of glass } \\
\text { specimen }\end{array}$ \\
\hline $\mathrm{JH}-3$ & $\begin{array}{l}600^{\circ} \mathrm{C} \\
400 \text { bars } \\
64 \text { hrs } \\
\text { Type } \mathrm{D}\end{array}$ & $\begin{array}{l}\text { dark grey and highly sintered massive; } \\
\text { black grains; pockets of clear, color- } \\
\text { less needle-like crystals }\end{array}$ & $\begin{array}{l}\text { significant crys- } \\
\text { tallization but } \\
\text { to a lesser ex- } \\
\text { tent than in } \mathrm{JH}-3\end{array}$ \\
\hline $17-8 *$ & $\begin{array}{l}400^{\circ} \mathrm{C} \\
400 \text { bars } \\
30 \text { days }\end{array}$ & $\begin{array}{l}\text { product sintered to solid mass; white } \\
\text { coating on the product }\end{array}$ & \\
\hline $40-L$ & $\begin{array}{l}400^{\circ} \mathrm{C} \\
300 \text { bars } \\
30 \text { days } \\
\text { Type C }\end{array}$ & $\begin{array}{l}\text { product sintered to solid mass; multi- } \\
\text { colored zones of crystallization on } \\
\text { surface of sintered product }\end{array}$ & $\begin{array}{l}\text { new peaks at } \\
13.9,20.7,26.3 \\
28.6,29.9,30.7 \\
\text { and } 35.502 \theta\end{array}$ \\
\hline $46-L$ & $\begin{array}{l}400^{\circ} \mathrm{C} \\
300 \text { bars } \\
30 \text { days } \\
\text { Type } D\end{array}$ & $\begin{array}{l}\text { wet compacted mass; open end of tube } \\
\text { has light green crust with (a) lemon } \\
\text { yellow euhedral crystals (approx. } 3 \\
\text { large ones); (b) rectangular colorless } \\
\text { crystals; (c) small euhedral colorless } \\
\text { high refractive index crystals; (d) } \\
\text { small clusters of white needle crystals }\end{array}$ & $\begin{array}{l}\text { new peaks at } \\
13.8,15.7,20.0 \text {, } \\
26.1,29.9 \text { and } \\
30.7{ }^{2} 2 \theta\end{array}$ \\
\hline 48-L & $\begin{array}{l}200^{\circ} \mathrm{C} \\
300 \text { bars } \\
30 \text { days } \\
\text { Type } \mathrm{D}\end{array}$ & $\begin{array}{l}\text { damp compacted mass: (a) large lemon } \\
\text { yellow gum drop shaped crystal visible } \\
\text { to the unaided eye; crystal is made up } \\
\text { of growth of many smaller euhedral crys- } \\
\text { tals; (b) crystal (a) is resting upon a } \\
\text { mass of high refractive index colorless } \\
\text { euhedral crystals }\end{array}$ & \\
\hline
\end{tabular}

*leaked during run, but apparently without substantive materials transport. 


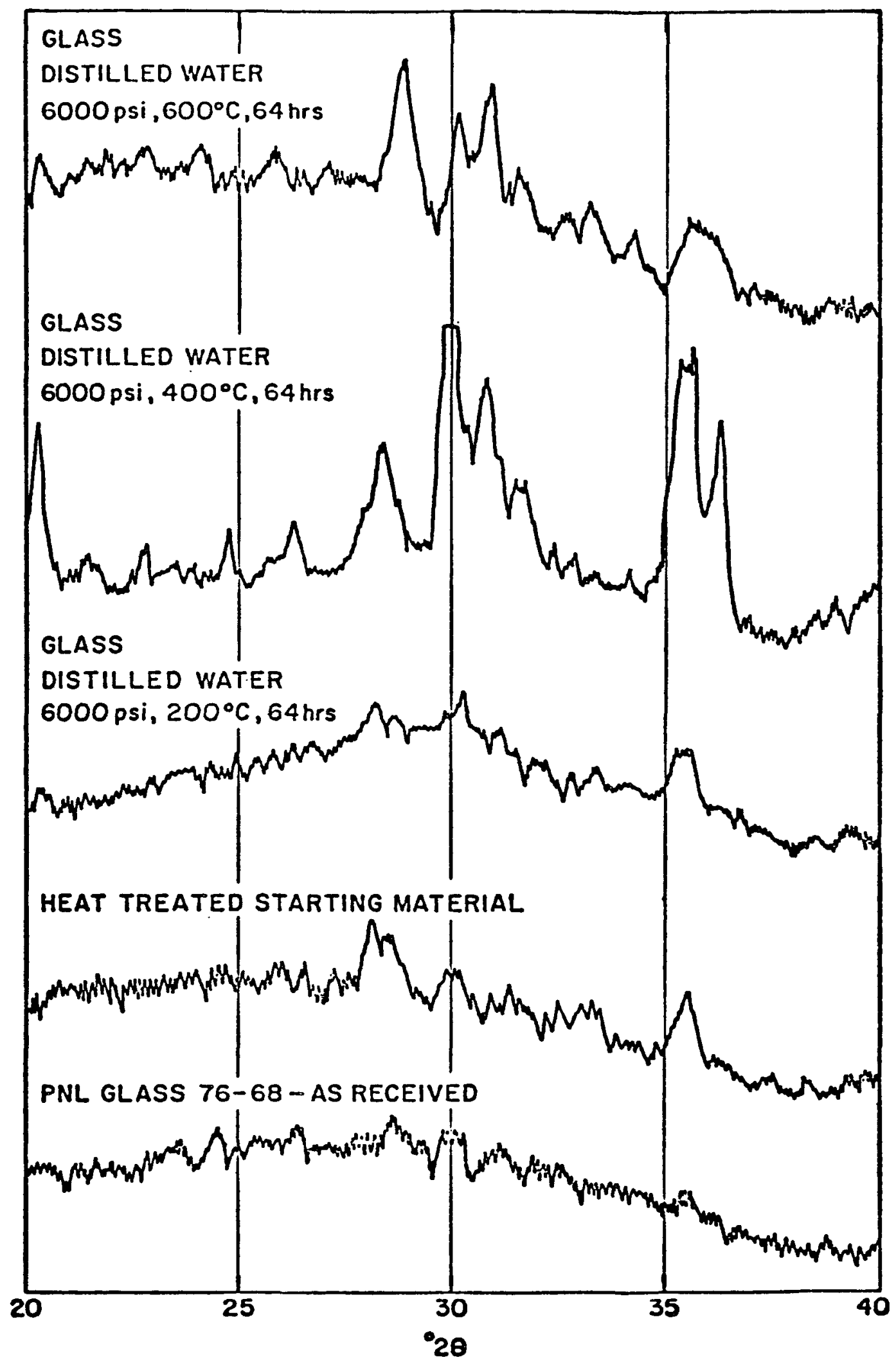

FIG. 6.2. X-ray diffractograms of 76-68 glass before and after hydrothermal treatments. 


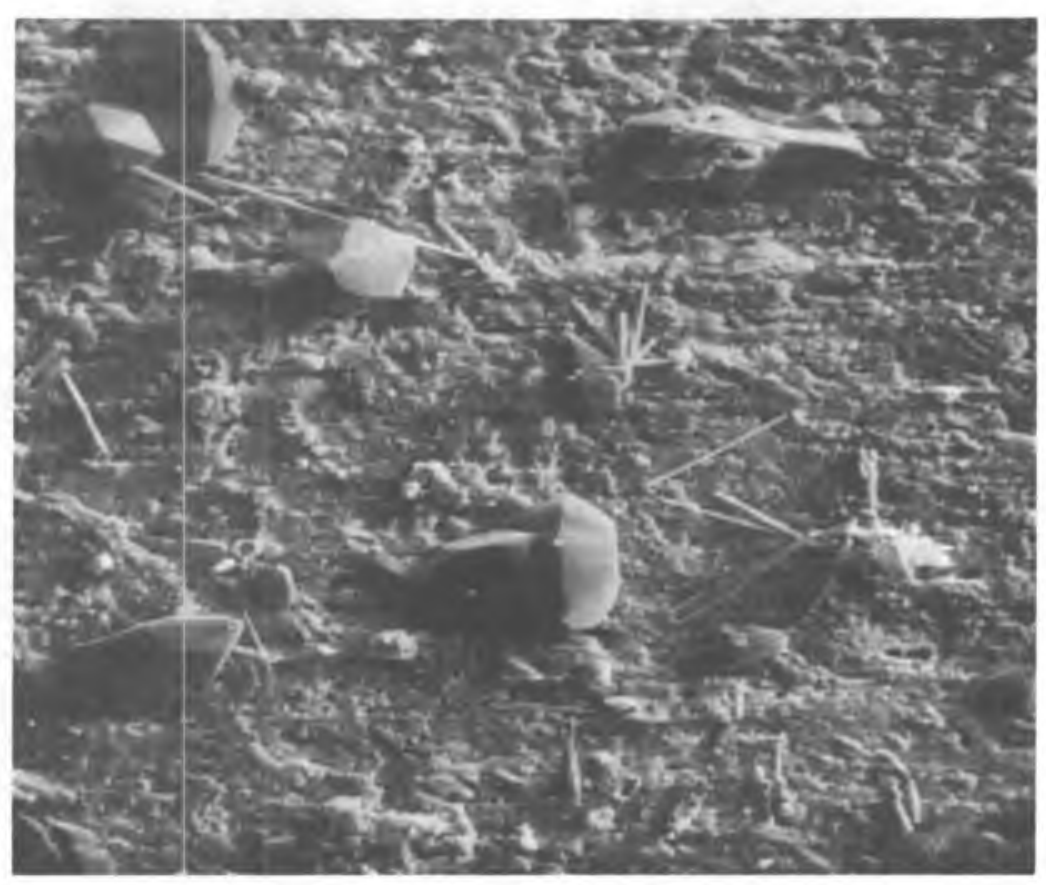

(a) Crystal growth on the surface of glass 76-68 treated hydrothermally at $400^{\circ} \mathrm{C}$ (Run 17-8).

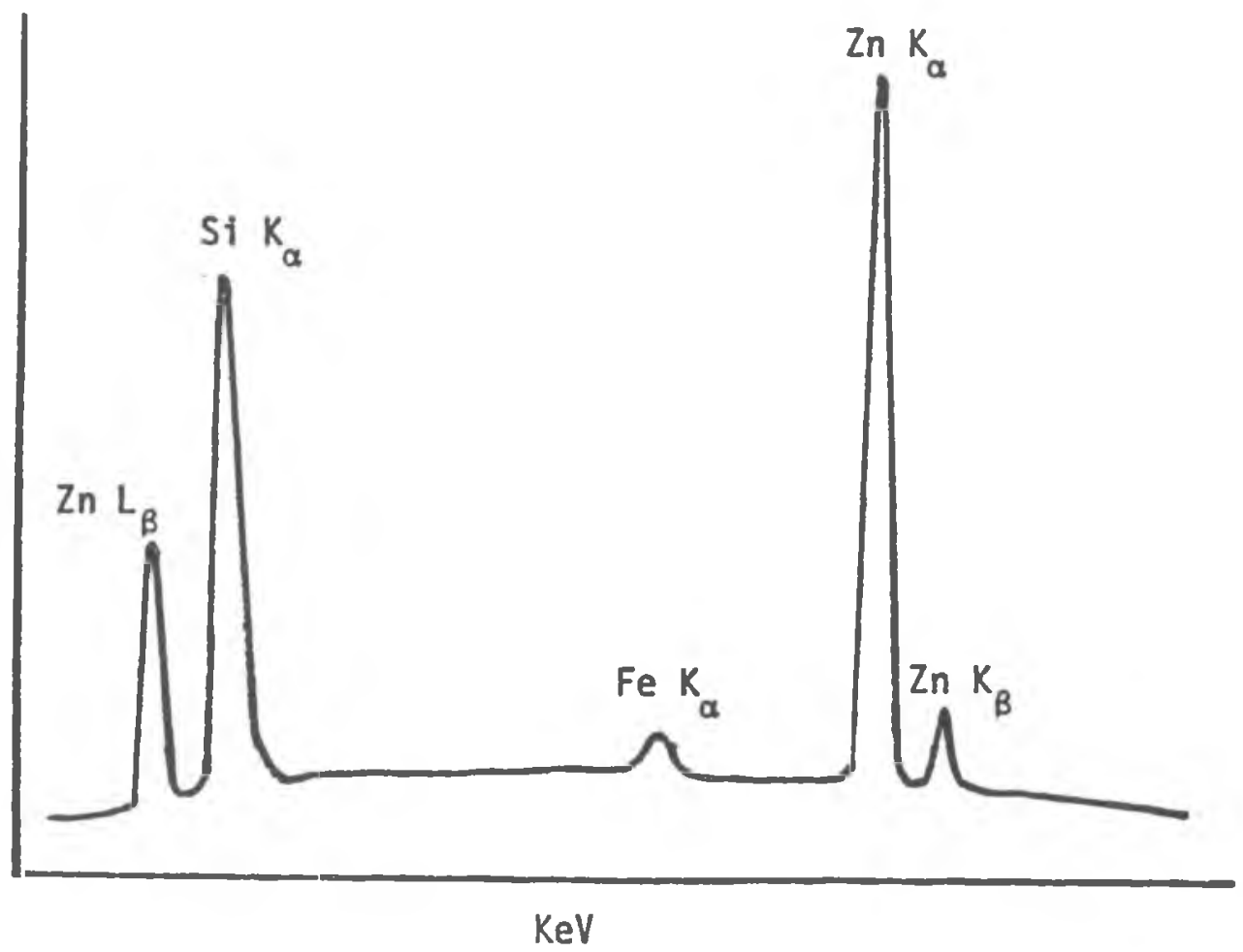

(b) EDX chemistry of the needle crystals in Run 17-8. 


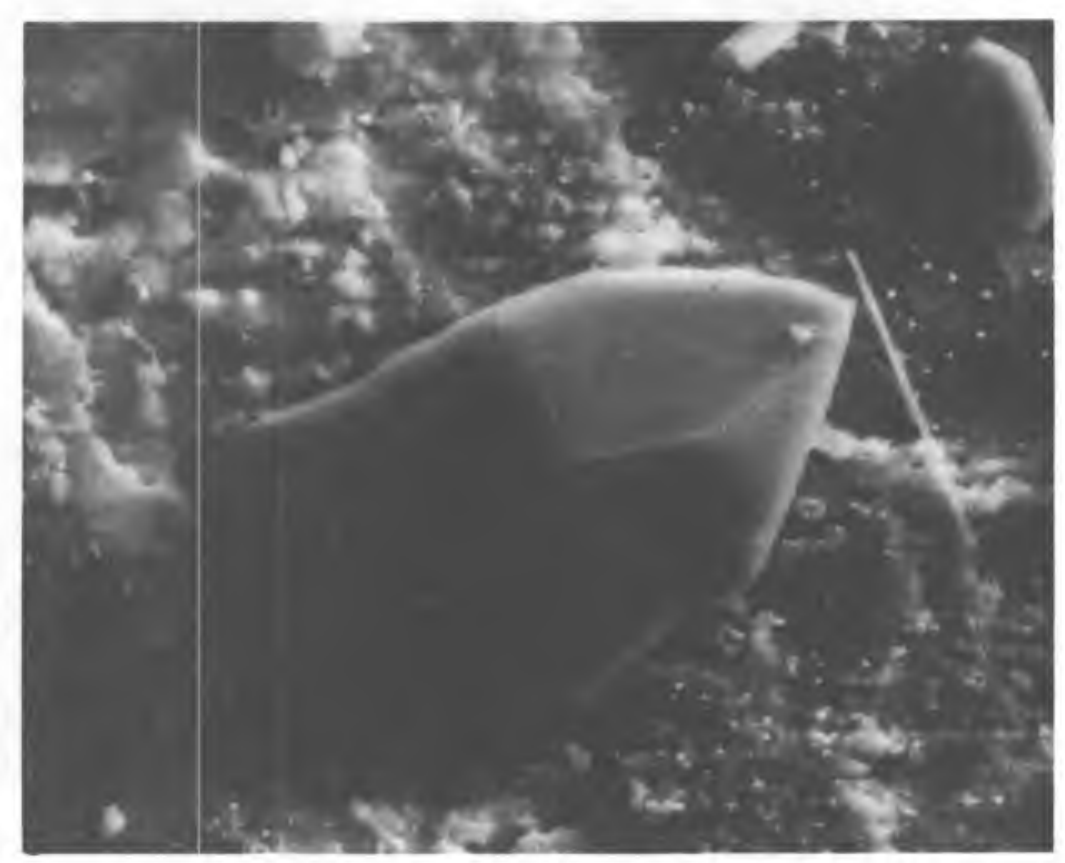

(a) Enlargement of the quartz crystal from Fig. 6.3 (a) (long dimension is $\sim 60 \mu \mathrm{m})$.

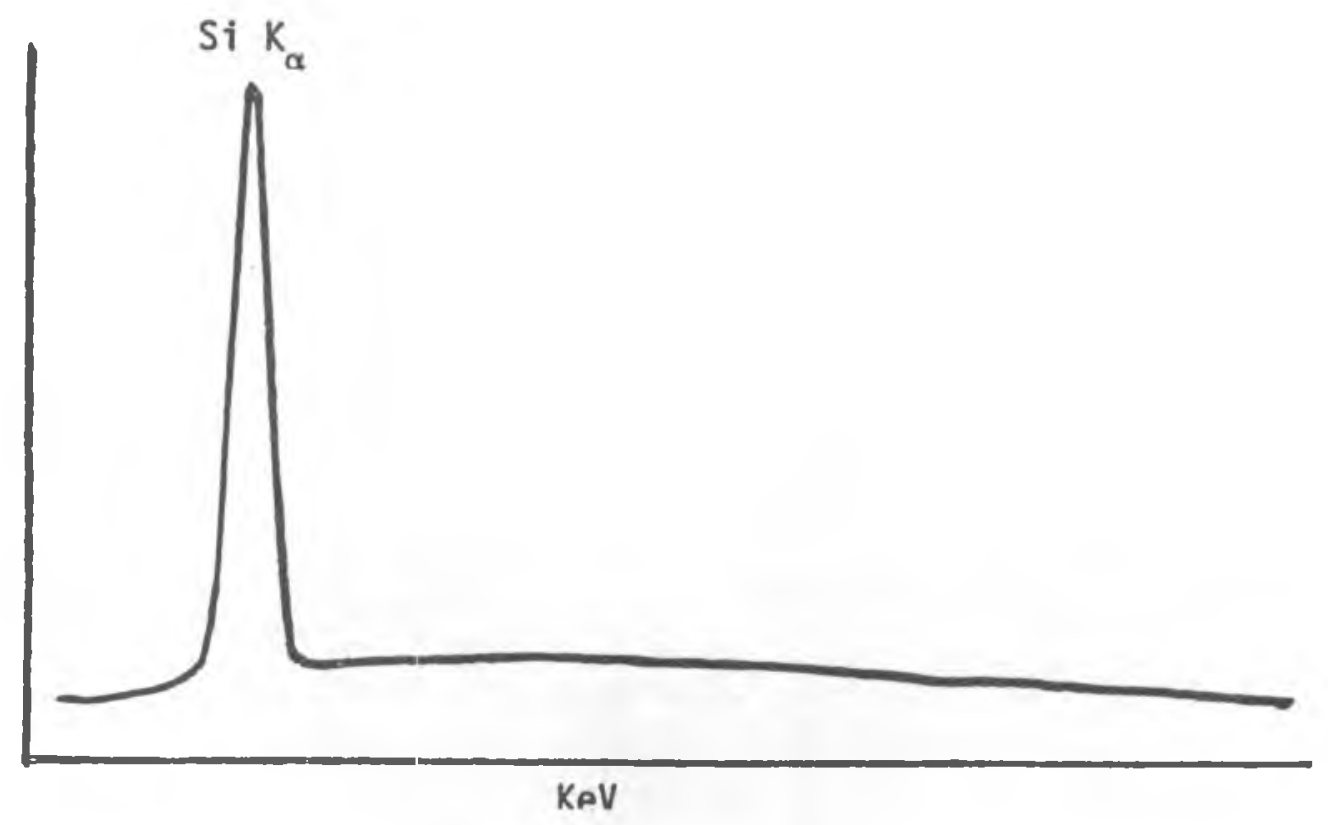

(b) EDX chemistry of quartz crystal.

FIG. 6.4 
- Euhedral, enantimorphic quartz crystals $\sim 50 \mu \mathrm{m}$ diameter (EDX chemistry, Si);

- Needle crystals $150 \mu \mathrm{m}$ in length [EDX chemistry, $\mathrm{Zn}(\mathrm{Fe}) \mathrm{Si}$ ].

The probable phase identification for the second form is willemite, $\mathrm{Zn}_{2} \mathrm{SiO}_{4}$, with minor iron substituting for zinc. The other phase is unquestionably low quartz. These figures offer dramatic evidence of the attack of the hydrothermal solutions on glass 76-68. Reference to Table 3.2 shows that ZnO constitutes only 5.0 wt \% of the glass. It appears that either zinc was dissolved from the glass, combined with silica and crystallized as a zinc silicate or zinc silicate is one of the resistant phases in the glass and remains, along with crystalline quartz after the rest of the glass has been dissolved away. We currently favor the first explanation because Battelle-Northwest workers have not been able to identify crystalline $\mathrm{Zn}_{2} \mathrm{SiO}_{4}$ in devitrified $76-68$ by XRD or SEM, so the $\mathrm{Zn}$ would appear to be well distributed throughout the glass. A great deal more work will be necessary in the coming year to determine the mechanisms and kinetics of glass dissolution and the partitioning of elements from the glass between the solutions and crystalline phases.

Another of the runs in Table 6.1 gave crystalline phases made up of many more of the elements in glass 76-68. Run 46-L was conducted at $400^{\circ} \mathrm{C}, 300$ bars pressure for 30 days with distilled water as the hydrothermal fluid. Three morphologically distinct crystalline phases were identified on the surface of the charge:

- Elongated euhedral -60 $\mu \mathrm{m}$ long (EDX chemistry, Na on energy continuum) - Fig. 6.5;

- Lath-like crystals $-500 \mu \mathrm{m}$ long (EDX chemistry, $\mathrm{Na}, \mathrm{Fe}$ and Si);

- Radiating lath-Tike crystais $-5 \mu \mathrm{m} \times-200 \mu \mathrm{m}$ (EDX chemistry, Na, $\mathrm{K}, \mathrm{Ca}, \mathrm{Ti}$ and $\mathrm{Zn}$ as minor components and $\mathrm{Fe}$ and $\mathrm{Si}$ as major components).

The EDX chemistry of the first phase is unusual (Fig. 6.5[b]). It is composed of the X-ray emission of $\mathrm{NaK}_{\alpha}$ superimposed upon an energy continuum that peaks in the neighborhood of $2 \mathrm{KeV}$. Our SEll specialists believe that this energy continuum could be caused by the presence in the phase of one or more elements that are below Na, the lower limit of detection of the EDX apparatus. Since the glass contains $10 \%$ by weight $\mathrm{B}_{2} \mathrm{O}_{3}$, it is 


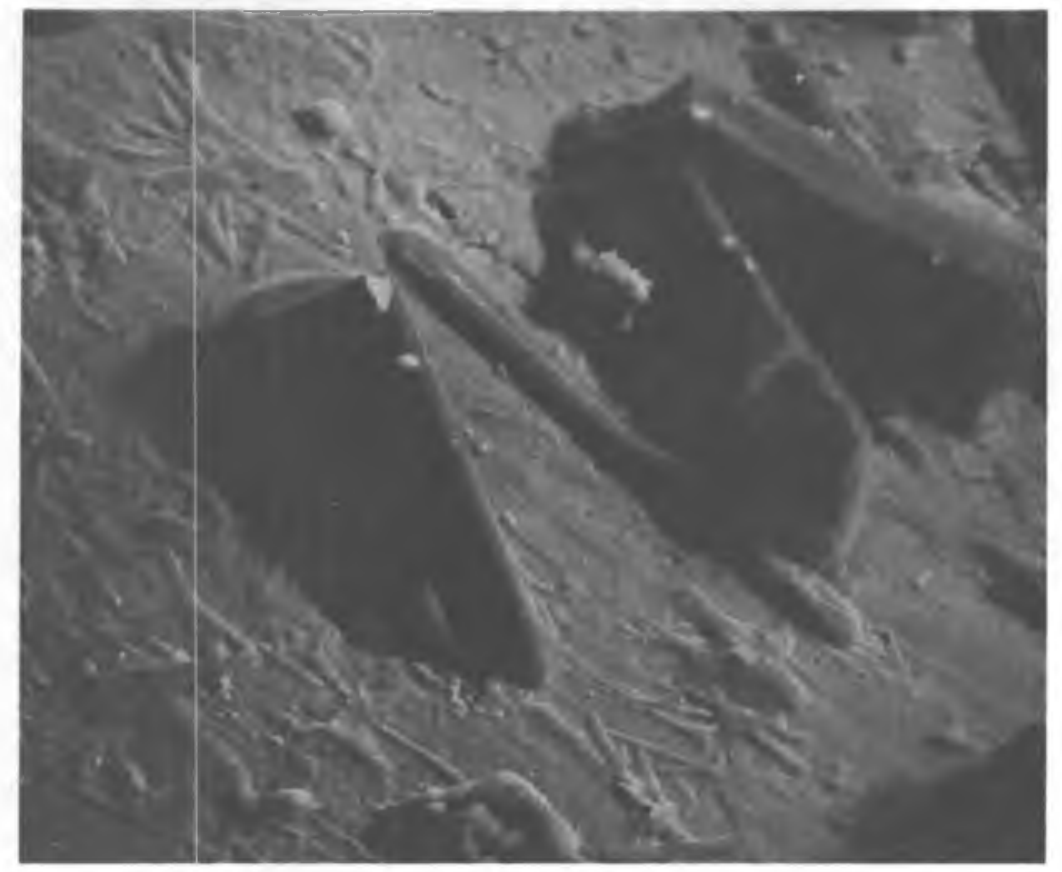

(a) Elongate euhedral crystals on the surface of the product from Run $46-L$.

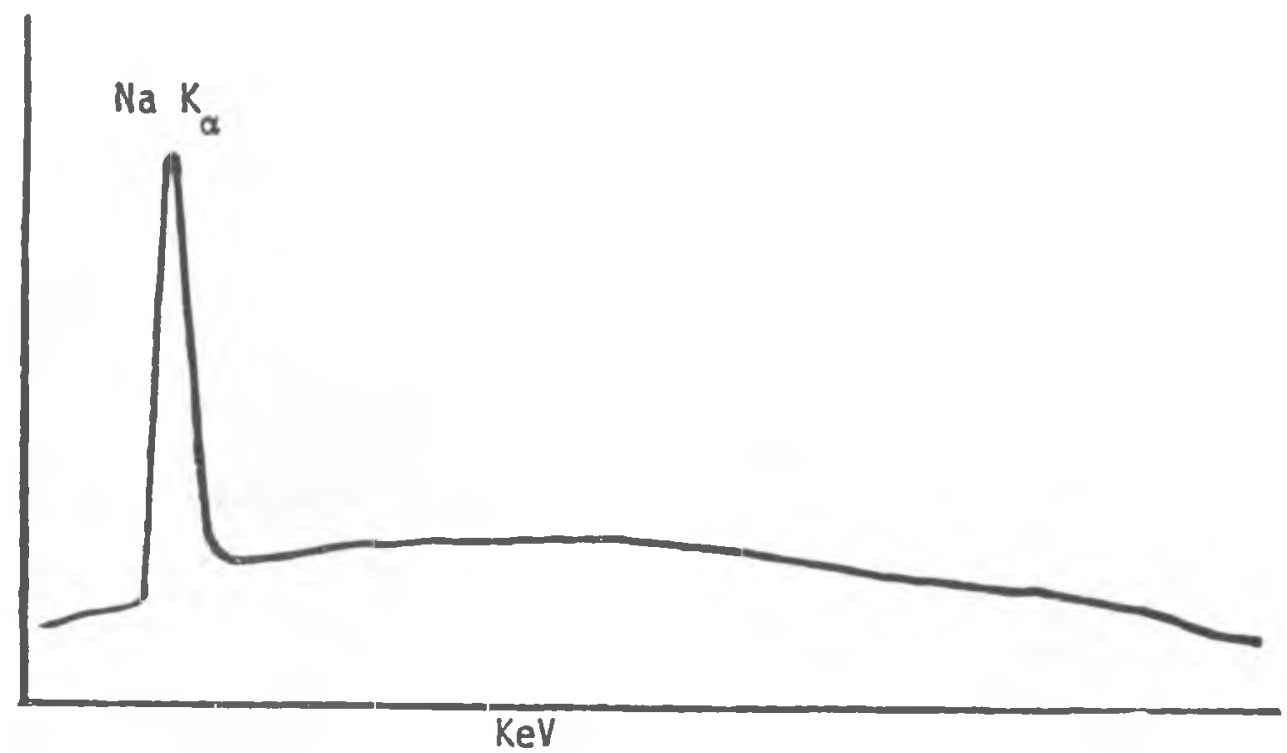

(b) EDX chemistry for the elongate crystals.

FIG. 6.5 
a reasonable inference that this phase may be an Na-borate composition. The crystals are large enough so that hand-picked crystals can be examined by $X$-ray diffraction techniques in the coming months.

The extensive hydrothermal reactions were not confined to the $400^{\circ} \mathrm{C}$ treatments. Run 48-6 in Table 6.1 was the product of 76-68 glass treated for 30 days at $200^{\circ} \mathrm{C}$ with Hanford ground water. Optical microscopy showed a sintered mass with growth of three distinct crystalline morphologies either on the charge or on the inner surface of the gold capsule:

- Lemon-yellow hemispherical crystalline aggregate $-500 \mu \mathrm{m}$ in diameter (Fig. 6.6) (EDX chemistry, $U$ and Si with minor $\mathrm{Na}, K$ and $T i$ );

- Equant euhedral crystal $i 25 \mu \mathrm{m}$ on an edge (Fig. 6.7) (EDX chemistry, $\mathrm{Na}, \mathrm{Si}, \mathrm{U}, \mathrm{K}, \mathrm{Ca}, \mathrm{Ti}$ and $\mathrm{Fe}$ );

- Fibrous aggregate -25 um long (EDX chemistry, $\mathrm{Na}, \mathrm{Fe}$ and $\mathrm{Si}$ ).

The first crystalline phase described occurred on the inner surface of the gold ampul. It appeared to be a mineralized drop that crystallized on cooling. The lemon-yellow color is an almost certain indication that the $U$ is present in the hexavalent state. Phase identification of this and other U-containing crystals will be a high priority in the coming year. Our colleague, Professor D. K. Smith, an expert on U minerals, will assist in this work.

All of the runs discussed so far were made with the 50 wt \% water content (type D). However, even with only small amounts of water present (type C) hydrothermal conditions produced substantial modifications of the 76-68 glass. In the product of run 40-L, small euhedral crystals with EDX chemistry of $\mathrm{Na}, \mathrm{Si}, \mathrm{U}, \mathrm{Ca}, \mathrm{Ti}$ and Fe were identified by SEM. The presence of so many of the elements from the original glass in a crystalline phase indicates attack on at least the surface of the sintered mass of glass.

6.2.2. Hydrothermal Treatmeni of Basalts. In Section 2.0 , we discussed the scenario where the waste remains in the storage canister, but 


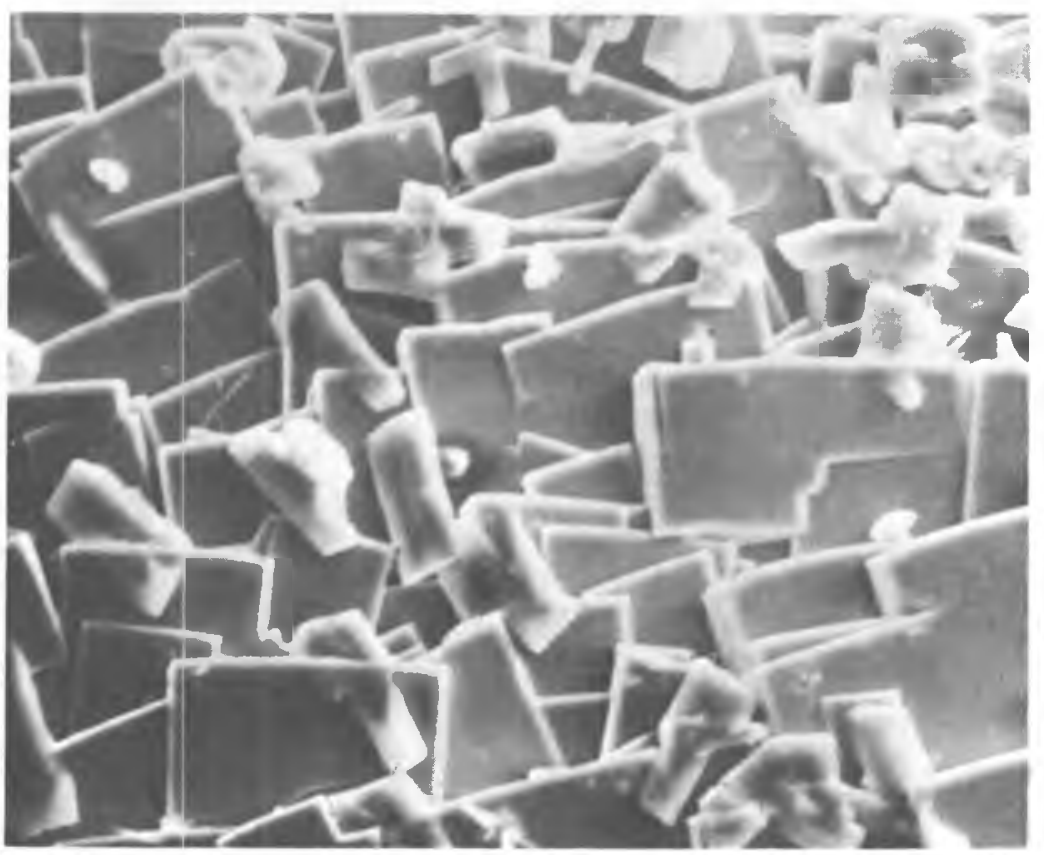

FIG. 6.6 Magnified view of surface features of $\sim 500 \mu \mathrm{m}$ U-rich crystalline growth on glass $76-68$ hydrothermally treated at $200^{\circ} \mathrm{C}$ (Run $48-\mathrm{L}$ ).

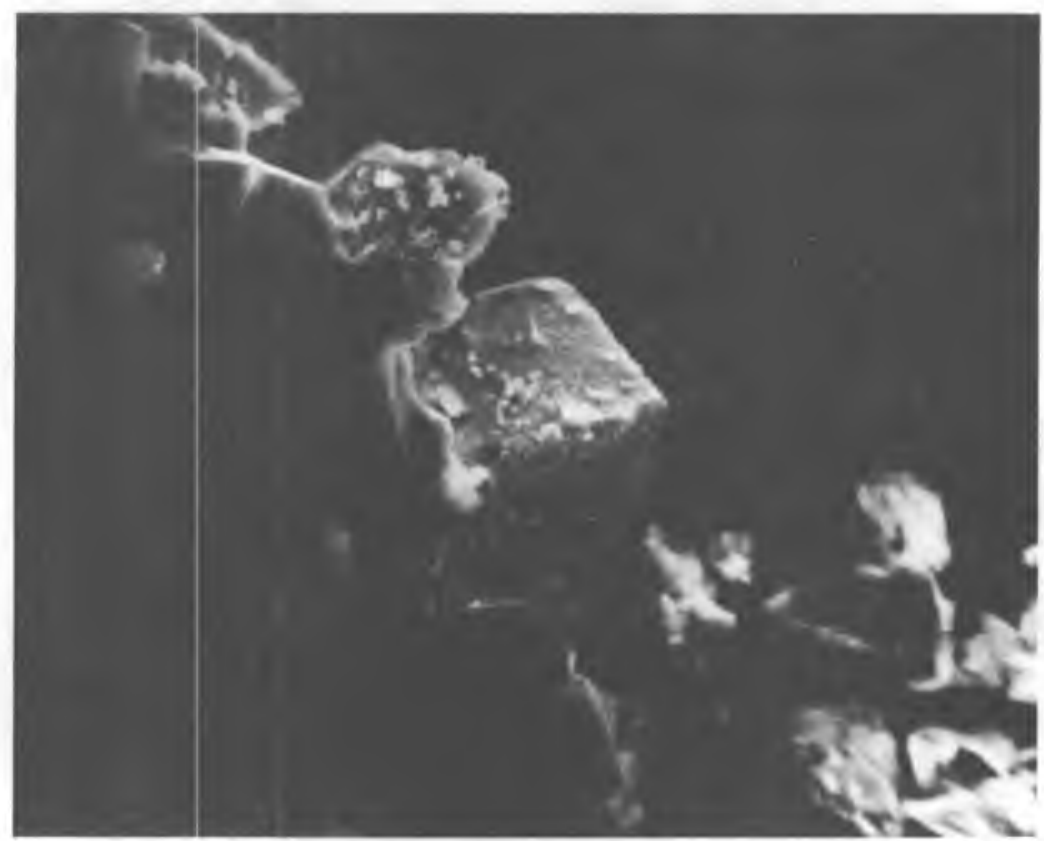

FIG. 6.7 Equant $125 \mu \mathrm{m}$ crystal on the surface of the product of Run 48-L. 
provides heat to nearby basalt which can induce "contact metamorphism," especially in the presence of mineralizing fluids under pressure; i.e., hydrothemal fluids. We have included basalt + water specimens in all of our runs in order to examine this potential contact metamorphism and to know what to expect from the basalt where waste-basalt mixtures are treated hydrothermally under the same conditions.

As can be seen from a scan of the run tables, there were no obvious alterations of the two basalts evident from the optical and $X$-ray observations in any of the hydrothermal experiments conducted to date. This observation is in agreement with the results of Hawkins and Roy (1963) discussed in Section 3.0. It is also consistent with the observations of Coombs, et al.,(1959), who found that, al though zeolites are the equilibrium low-grade metamorphic alteration products of the plagioclase in basalt, both natural plagioclase and synthetic anorthite produced no zeolites even after 60 days of treatment at $250^{\circ} \mathrm{C}-300^{\circ} \mathrm{C}$ and 1,000 bars. No SEM/EDX characterization was performed on the basalt products.

Several experiments were also performed on a specimen of fracture fi11. The Umtanum Basalt contains contorted surfaces between the columns which frequently contain vein-filling materials. In the weathered outcrops, these appear as an iron-stained, clay-like material. However, when exposed at depth, the fresh fracture fills are glassy and can take on several colorations. From discussions with Rockwell Hanford Operations geologists, we learned that one of these appeared to be very common. It is a green-black glassy solid. A specimen of this fracture fill was provided for study. X-ray diffractograms of the fresh material indicated that it is amorphous. Heat treatment at $1,050^{\circ} \mathrm{C}$ for 24 hours devitrified it to high (a) cristobalite $\left(\mathrm{SiO}_{2}\right)$ and hematite $\left(\mathrm{are}_{2} \mathrm{O}_{3}\right)$ and a third, as yet unidentified, phase. The metastable formation of high cristobalite at.this temperature is in concert with known devitrification behavior of silica gels and is no surprise. 
This sample was subsequently treated hydrothermally with Hanford ground water under experimental conditions $C$ and $D$ at $400^{\circ} \mathrm{C}$. In both cases, the material reacted to produce well-developed $\sim 500 \mu \mathrm{m}$ long crystals which appeared to have zeolitic structure. Identification has not been confirmed, but the habit and chemistry suggest that it may be a member of the natrolite family of zeolites.

These fracture-fill materials will be very important to waste species migration from a basalt repository as well as to reactivity of the basalt, so we will continue to characterize them and study their low temperature hydrothermal interactions in the coming year.

\subsubsection{Hydrothermal Treatment of Waste-Basalt Mixtures. In this} section the emphasis will be on interactions of basalts with calcine and glass. As a scan of Run Tables 11-30 will indicate, by optical and X-ray methods, there appeared to be little or no interaction with the other two waste forms, supercalcine and SURF, in our first set of reconnaissance runs. Initial SEM examination was thus confined to calcine- and glass-containing runs.

Basalt-Calcine Experiments. Calcine is clearly the most reactive waste form under hydrothermal conditions and this is no surprise. Some of the phases in which the alkalis, $\mathrm{Na}, \mathrm{Cs}$ and $\mathrm{Rb}$, are probably present (unfortunately, we don't know for sure because most calcine phases are $X$-ray amorphous) are quite soluble in water. These amorphous phases might include $\mathrm{NaFeO}_{2},(\mathrm{Na}, \mathrm{Cs}, \mathrm{Rb})_{2} \mathrm{MoO}_{4},(\mathrm{Na}, \mathrm{Cs}, \mathrm{Rb})_{2} \mathrm{CrO}_{4}, \mathrm{Na}_{2} \mathrm{U}_{2} \mathrm{O}_{7}$ and so on. The fact that calcine is generally a high-surface-area powder further enhances the rate of dissolution of these phases.

Figures $6.8,6.9$ and 6.10 are SEM photomicrographs of some of the crystalline forms created during hydrothermal interactions between basalts and calcine. It is important to note that the chemistry of these crystals indicates that these were formed by interaction and not just alteration of basalt and calcine; i.e., certain of the new phase elements were originally present only in basalt or only in calcine. Figure 6.8 shows an $-100 \mu \mathrm{m}$ needle crystal growing from a highly faceted euhedral crystal in run $10 R-F$ $\left(400^{\circ} \mathrm{C}, 275\right.$ bars, 30 days, type D). The EDX chemistry of both crystals was similar, Na, Al, Mo, Si. One possible phase identification is the 


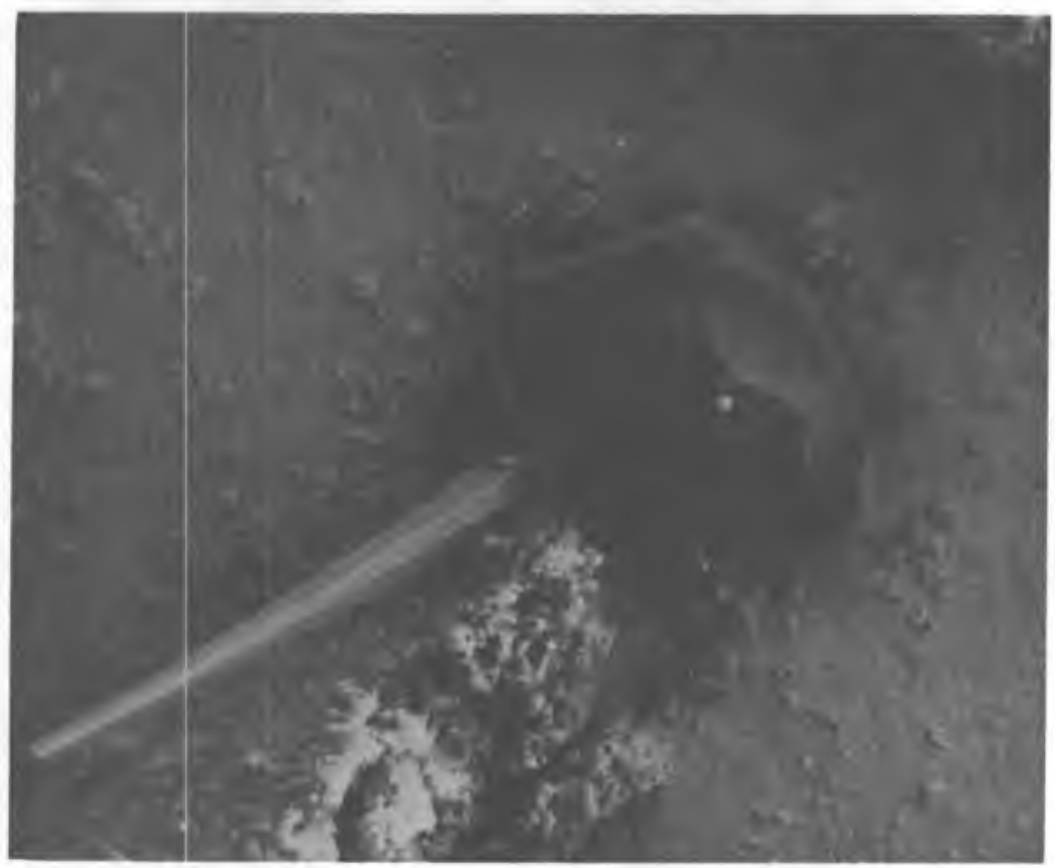

FIG. 6.8 Crystal development on the surface of a mixture of calcine PW-7a and basalt $\left[\mathrm{DDH}-3\right.$, hydrothermally treated at $400^{\circ} \mathrm{C}(\sim 100 \mu \mathrm{m}$ maximum dimension). Run 10R-F.

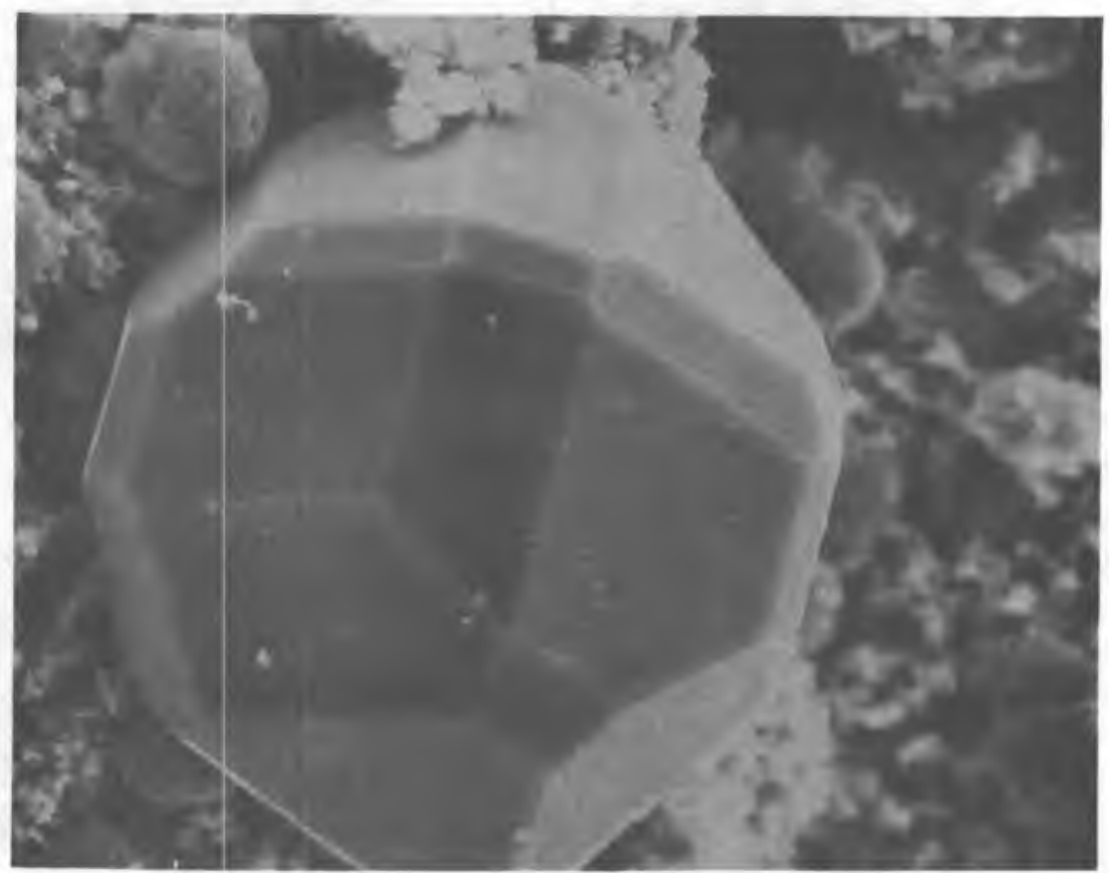

FIG. 6.9 This $\sim 20 \mu \mathrm{m} \mathrm{Na-pollucite} \mathrm{crystal} \mathrm{developed} \mathrm{on} \mathrm{the} \mathrm{surface} \mathrm{of}$ the product of Run 10R-F, calcine PW-7a and basalt DDH-3. 


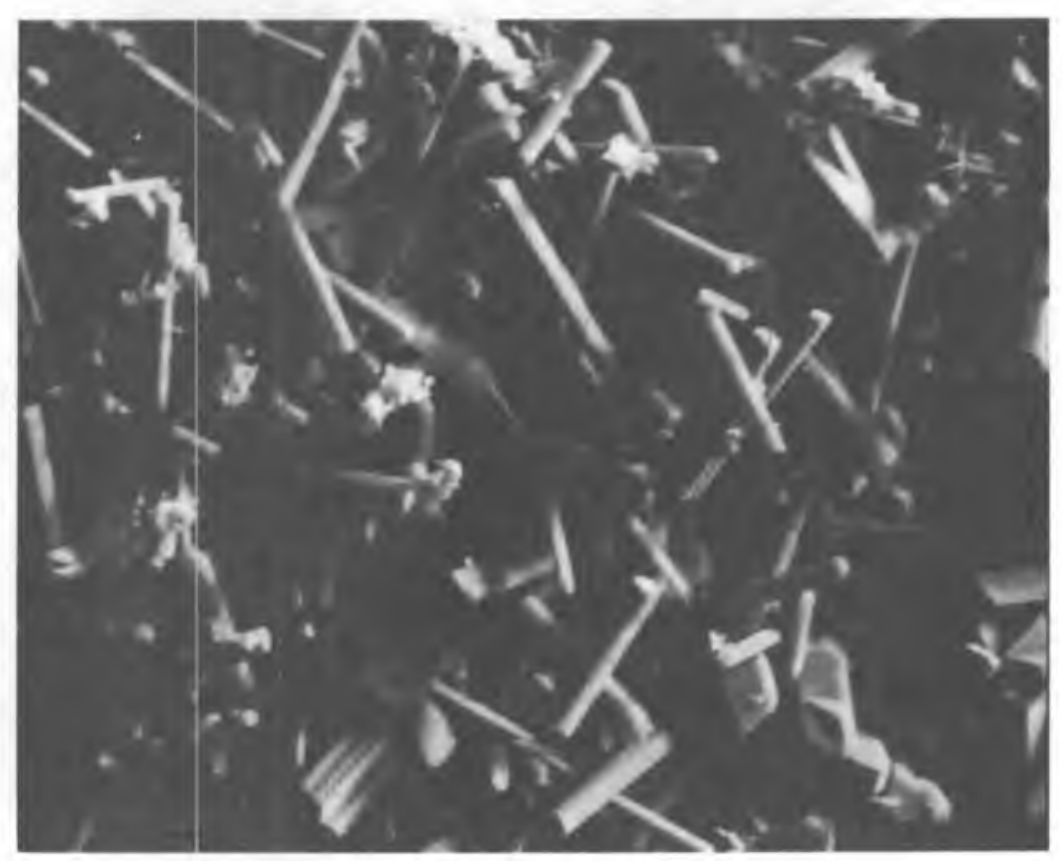

(a) Euhedral $30 \mu \mathrm{m}$ rod-1ike crystals from Run 6R-A that was hydrothermally treated under $10 w-w a t e r$ conditions at $400^{\circ} \mathrm{C}$.

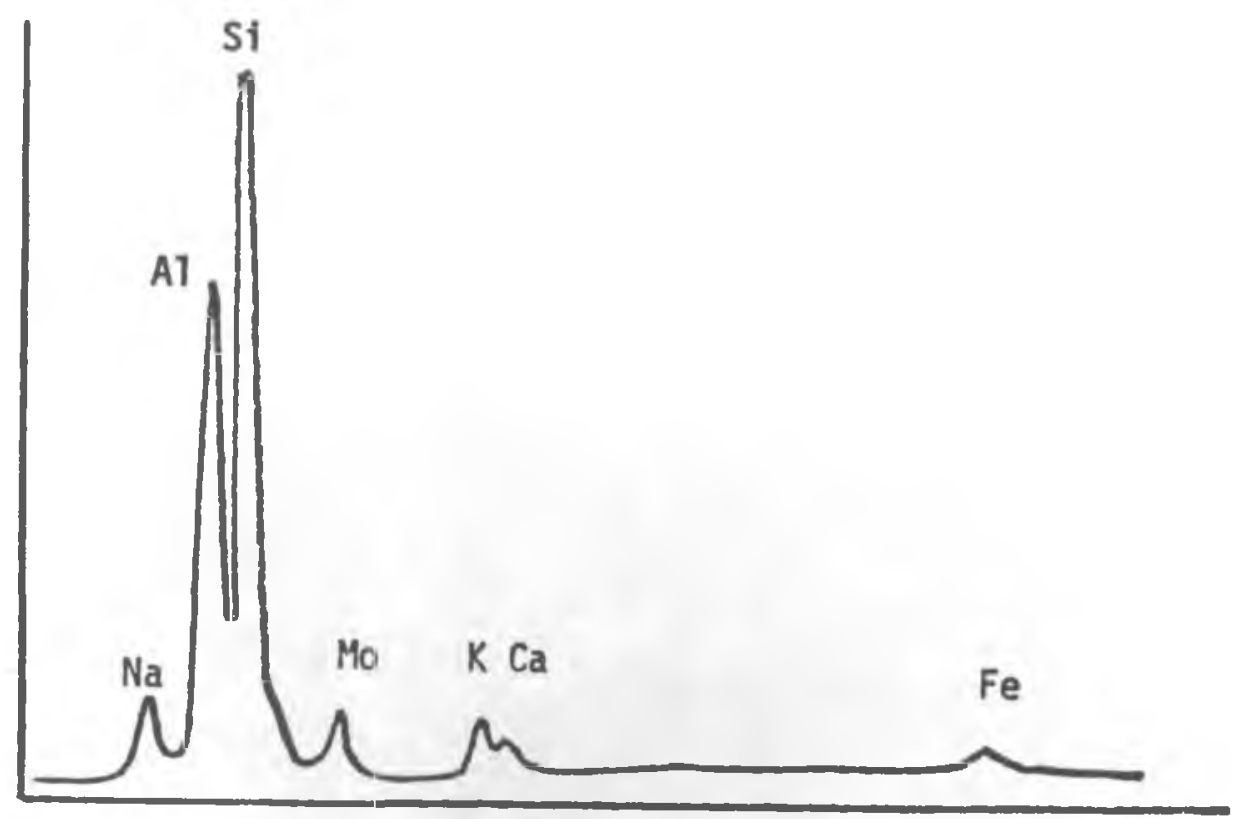

(b) EDX chemistry for crystal growth on Run 6R-A.

FIG. 6.10 
sodalite structure "Mo-nosean", $\mathrm{Na}_{8} \mathrm{Al}_{6} \mathrm{Si}_{6}{ }_{2}{ }_{24} \mathrm{MoO}_{4}$, mentioned in section 6.1. The highly perfect crystals found throughout the product of run $10 R-F$ and shown in Fig. 6.9 were easily recognized as cubic pollucite, $\mathrm{CsAlSi}_{2} \mathrm{O}_{6} \cdot \mathrm{nH}_{2} \mathrm{O}$ or its pseudocubic analog analcime, NaAlSi ${ }_{2} \mathrm{O}_{6} \cdot \mathrm{H}_{2} \mathrm{O}$. EDX chemistry was $\mathrm{Na}$, $\mathrm{Al}$, Si, Cs. He are calling this phase "Na-pollucite" to indicate that its composition falls somewhere in the pollucite-analcime solid solution series. As noted under " $X$-ray observations" for run $10 R-F$ and several other entries in the run tables, $X$-ray peaks consistent with the strongest peaks of pollucite were identified in the complex $X$-ray diffractograms of all calcine $\mathrm{PW}-7 \mathrm{7a}$ /basalt runs, $200^{\circ} \mathrm{C}$ as well as $400^{\circ} \mathrm{C}$, DDH- 3 and $\mathrm{BCR}-1$ basalts, and both low temperature (type $C$ ) and high water (type $D$ ). Figure 6.11 gives tracings of a portion of the diffractograms of the Ply-7a/BCR-1 mixture before and after hydrothermal treatment and the corresponding tracing for PW-7a/DDH-3 after treatment. The hatched peaks in the product are those attributable to Na-pollucite. This is a good example of the interplay between SEM/EDX and XRD that we will be utilizing increasingly in the coming year.

The two phases just discussed amplify the point that waste-basalt interactions have occurred. In the "Mo-nosean" phase $\mathrm{Na}$ and Mo are supplied by the calcine (some $\mathrm{Na}$ also could come from the basalts and the Hanford ground water) and $A I$ and $S i$ by the basalts. Similarly, the Cs in the Na-pollucite crystals must come from the calcine, while Al and Si can be supplied only by the basalts. To confirm that Na-pollucite can form during short hydrothermal treatments, we reacted Cs and Na hydroxides with plagioclase at $375^{\circ} \mathrm{C} / 270$ bars for one week. Na-pollucite formed readily (see Run Table 23). Finally, to further illustrate that interactions occurred even under the low-water type $C$ condition, Fig. 6.10 shows the growth of clusters of rod-like crystals observed in run 6R-A. The EDX chemistry is consistent with the "Mo-nosean" phase just described.

Basalt-Giass Experiments. One of our first experiments was designed to study the magnitude and rate of transport of species between glass 76-68 and basalt. In run 19-A, a chunk of basalt BCR-1 was loosely wrapped in platinum foil and placed in a gold capsule along with ground 76-68 glass and Hanford ground water. Run conditions were $400^{\circ} \mathrm{C}, 400$ bars for 2 weeks. The glass was severely altered, as was expected from the 


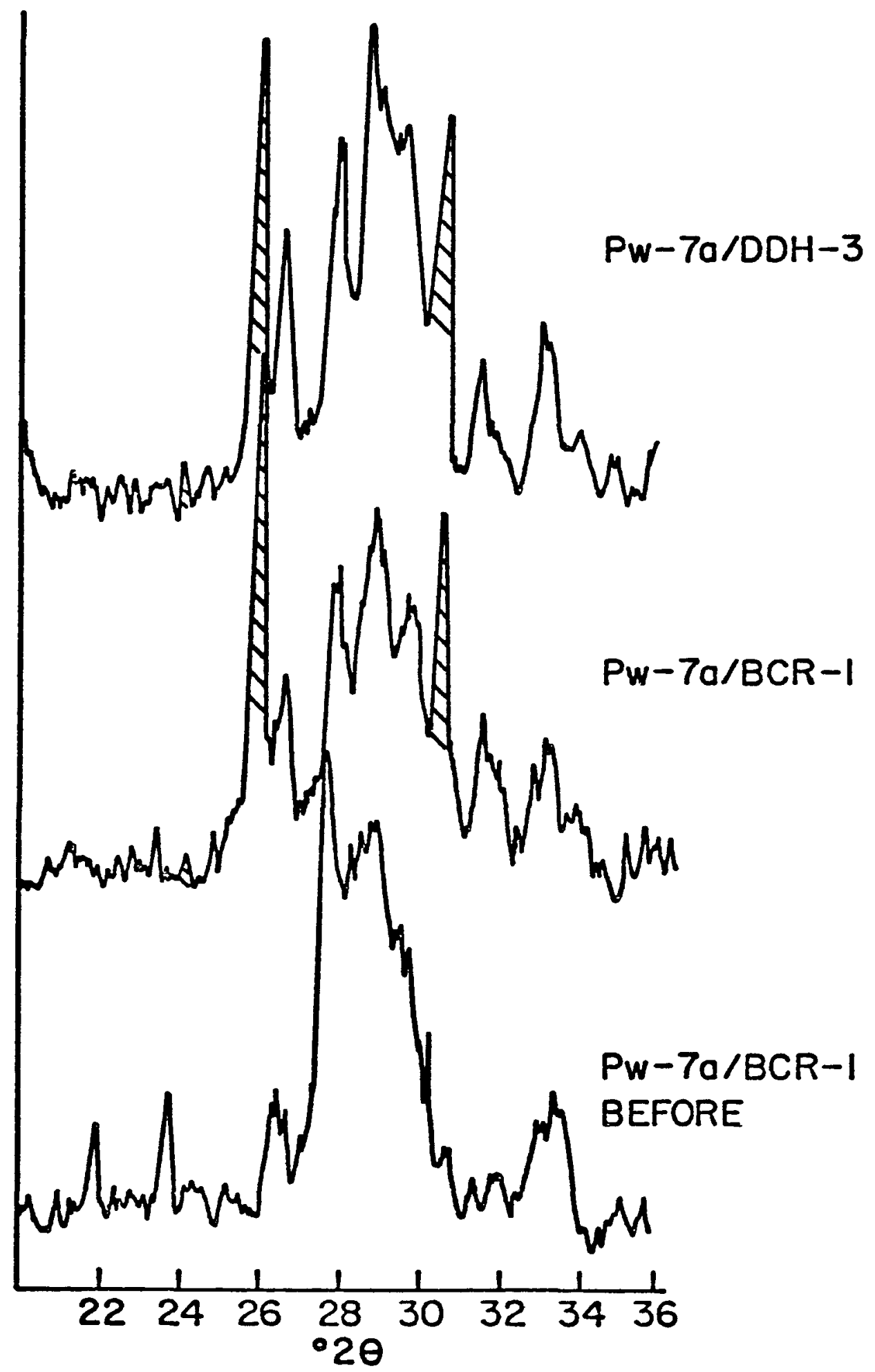

FIG. 6.11 Portions of the X-ray diffractograms of calcine Pl!-7a-basalt BCR-1 mixtures before and after hydrothermal treatment along with the corresponding diffractogram of $\mathrm{PW}-7 \mathrm{a}-\mathrm{DDH}-3$ after treatment. The Na-pollucite peaks are hatched. 
behavior of glass and water alone. In the preliminary SEM examination, no crystalline phases were identified which could unambiguously indicate wastebasalt interaction. Any Al-containing phase growing on the glass would have performed this function, because there is no Al in the glass. Two interesting features located on the surface of the glass are the quartz crystals shown in Fig. 6.12 and the uranium silicate in Fig. 6.13. These radiating clusters of lemon-yellow needles were often noted growing on hydrothermally treated glass 76-68. Again, we should emphasize that color suggests that the $U$ is hexavalent. Hexavalent $U$ compounds are usually quite soluble in water and both $\mathrm{Np}$ and $\mathrm{Pu}$ have considerable similarity to $U$ in solution chemistries. Once we identify in what phases the $U$ has crystallized, we will synthesize the phases and perform detailed experiments on their stability in solutions under all relevant repository conditions.

Several other interesting features were identified during the SEM characterization of basalt-glass mixtures. The rosette growth shown in Fig. 6.14 has EDX chemistry $\mathrm{Na}, \mathrm{Si}, \mathrm{K}, \mathrm{Ca}$ and Fe. The small hexagonal prism in the upper right corner has a similar EDX chemistry but without Ca. A different morphology for the Zn-Si-rich phase described previousiy is shown in Fig. 16.15. He frequentiy noted highly crystalline phases which had EDX chemistry consisting of the alkaline earths $\mathrm{Ca}, \mathrm{Sr}$ and $\mathrm{Ba}$ plus Mo. Some were rich in $\mathrm{Ca}$ with minor $\mathrm{Sr}$ and others were rich in $\mathrm{Ba}$ again with minor Sr. Our tentative phase identification is a scheelite structure solid solution phase, $(\mathrm{Ca}, \mathrm{Sr}, \mathrm{Ba}) \mathrm{MoO}_{4}$. Figure 6.16 shows one of these crystals. These scheelite structure phases may be the primary hosts for ${ }^{90} \mathrm{Sr}$ after waste-basalt interactions and, if this is confirmed, would be the subject of detailed study in the coming year.

Discussion and Summary. The following points can be made based on the preliminary reconnaissance hydrothermal experiments conducted during FY 1977.

- Waste-basalt interactions can occur in a matter of days under hydrothermal conditions at temperatures as low as $200^{\circ} \mathrm{C}$, the lowest temperature studied to date.

- Calcine PW-7a was by far the most reactive waste. Several crystalline phases identified in hydrothermal calcine-basalt reaction products demonstrated unambiguously the occurrence of waste-basalt interactions. 




(a) Doubly terminated $200 \mu \mathrm{m}$ long crystals developed on surface of glass hydrothermally treated with BCR-1 at $400^{\circ} \mathrm{C}$ (Run 19-A).

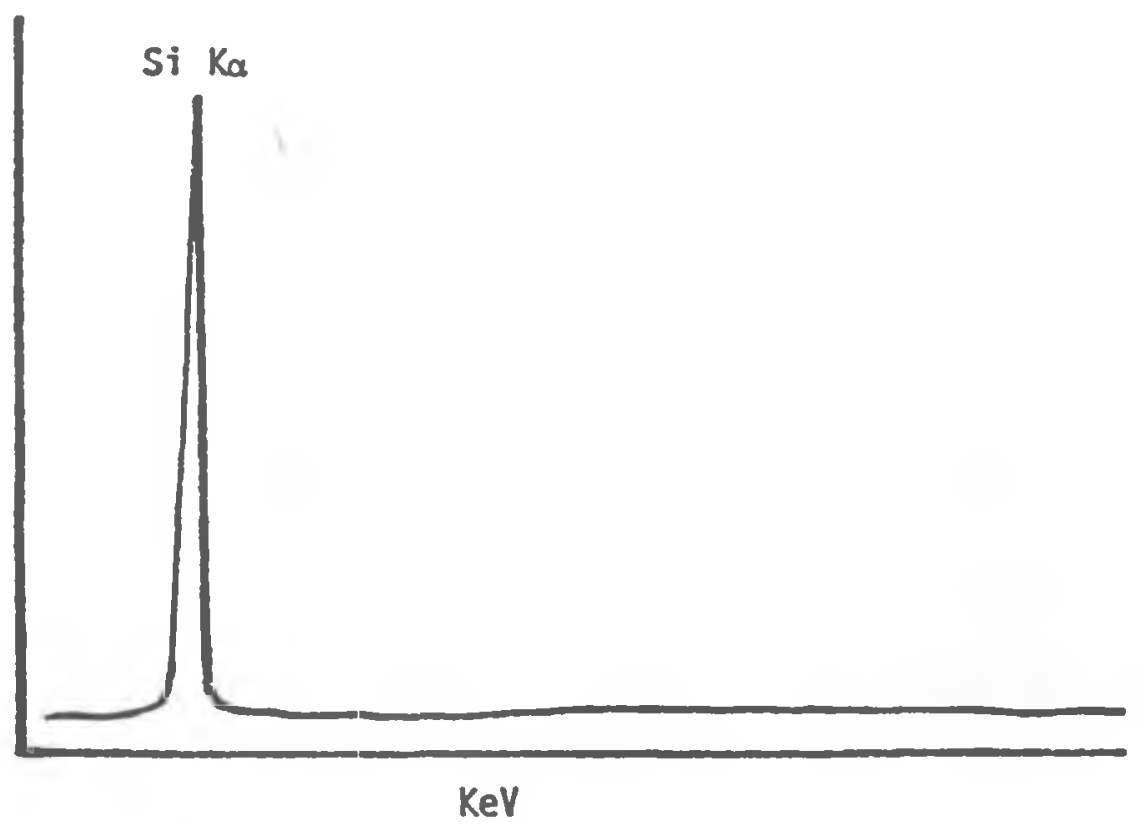

(b) The EDX chemistry indicates $\mathrm{SiO}_{2}$, almost surely quartz.

FIG. 6.12 


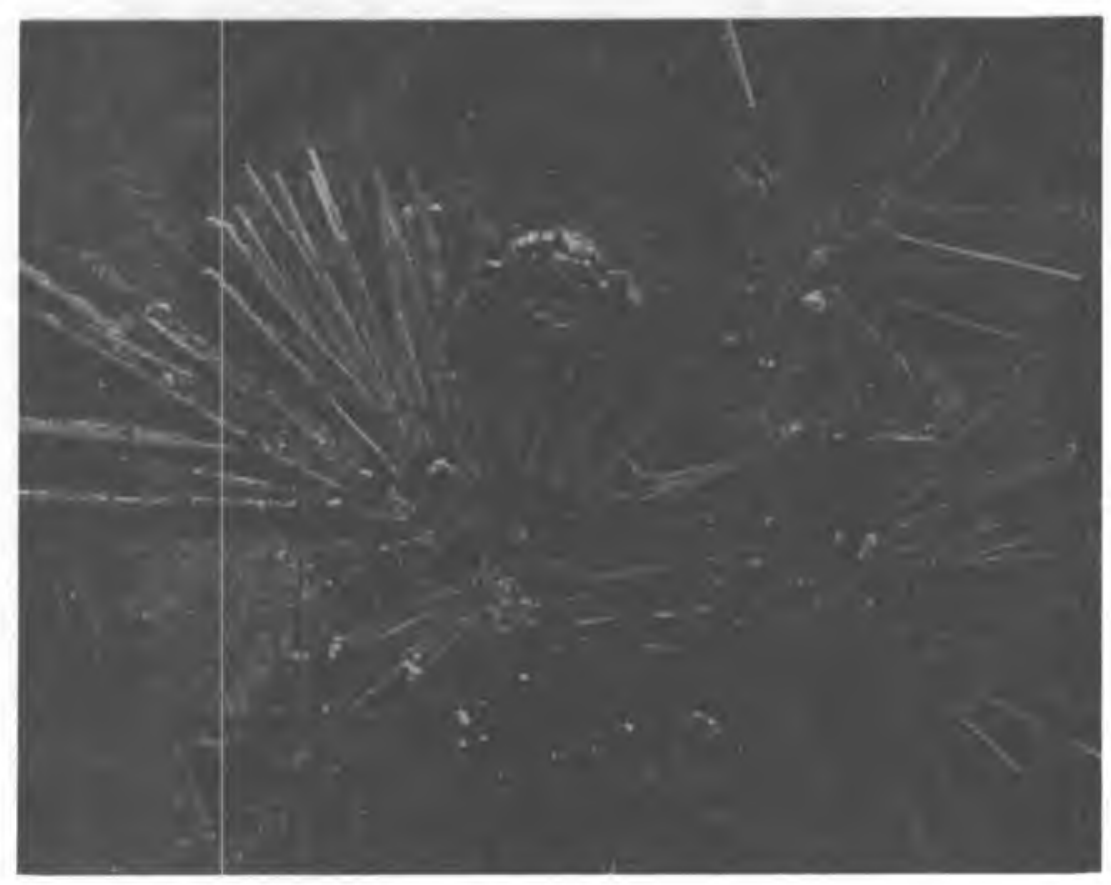

(a) Clusters ( 1,000 $\mu \mathrm{m}$ across) of a lemon-yellow crystalline phase on the surface of glass that has been hydrothermally treated in the presence of BCR- 1 at $400^{\circ} \mathrm{C}$ (Run $19-A$ ).

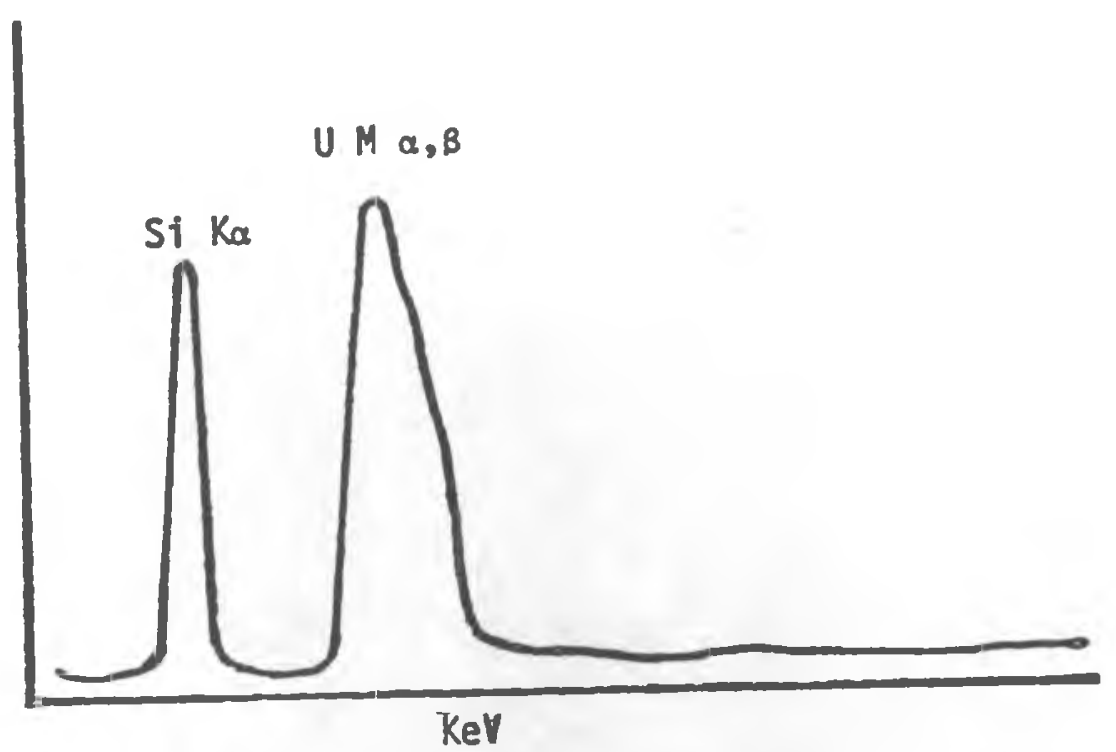

(b) EDX chemistry for the radiating needle crystals.

FIG. 6.13 


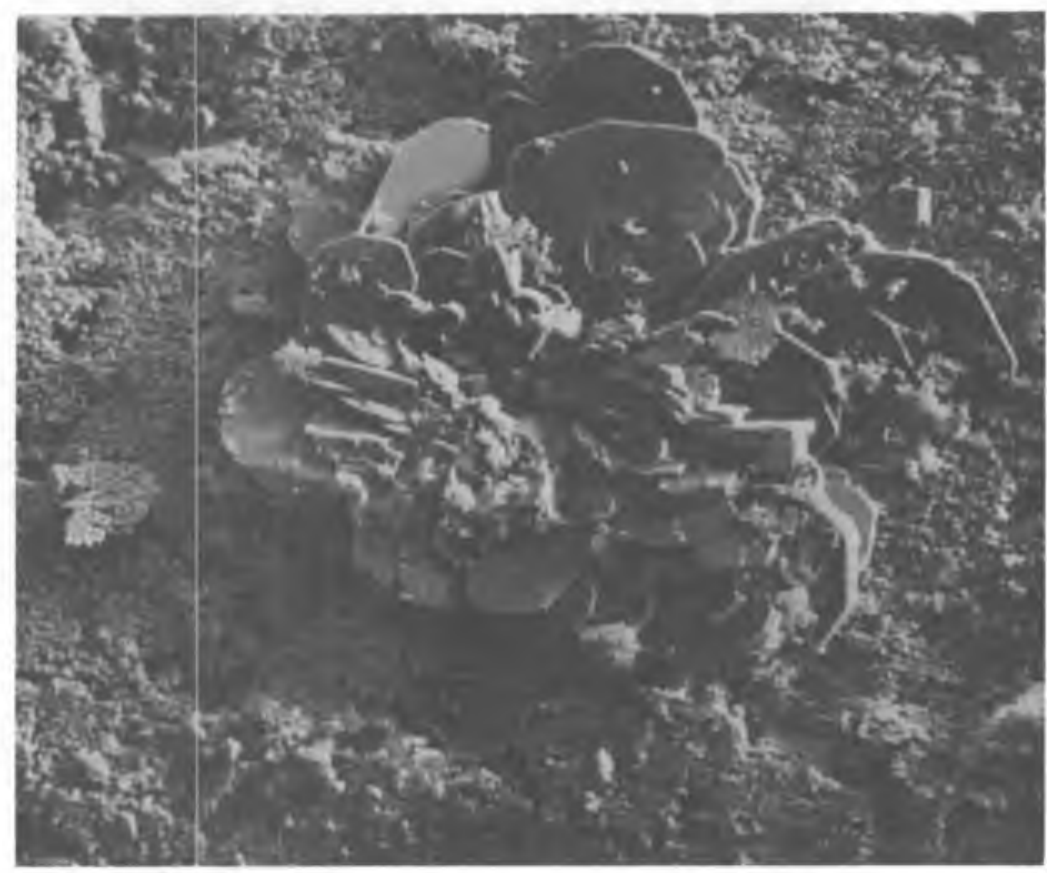

(a) Rosette crystal development, $\sim 400 \mu \mathrm{m}$ in diameter, on a glass plus DDH-3 mixture hydrothermally treated at $400^{\circ} \mathrm{C}$ (Run 10R-G).

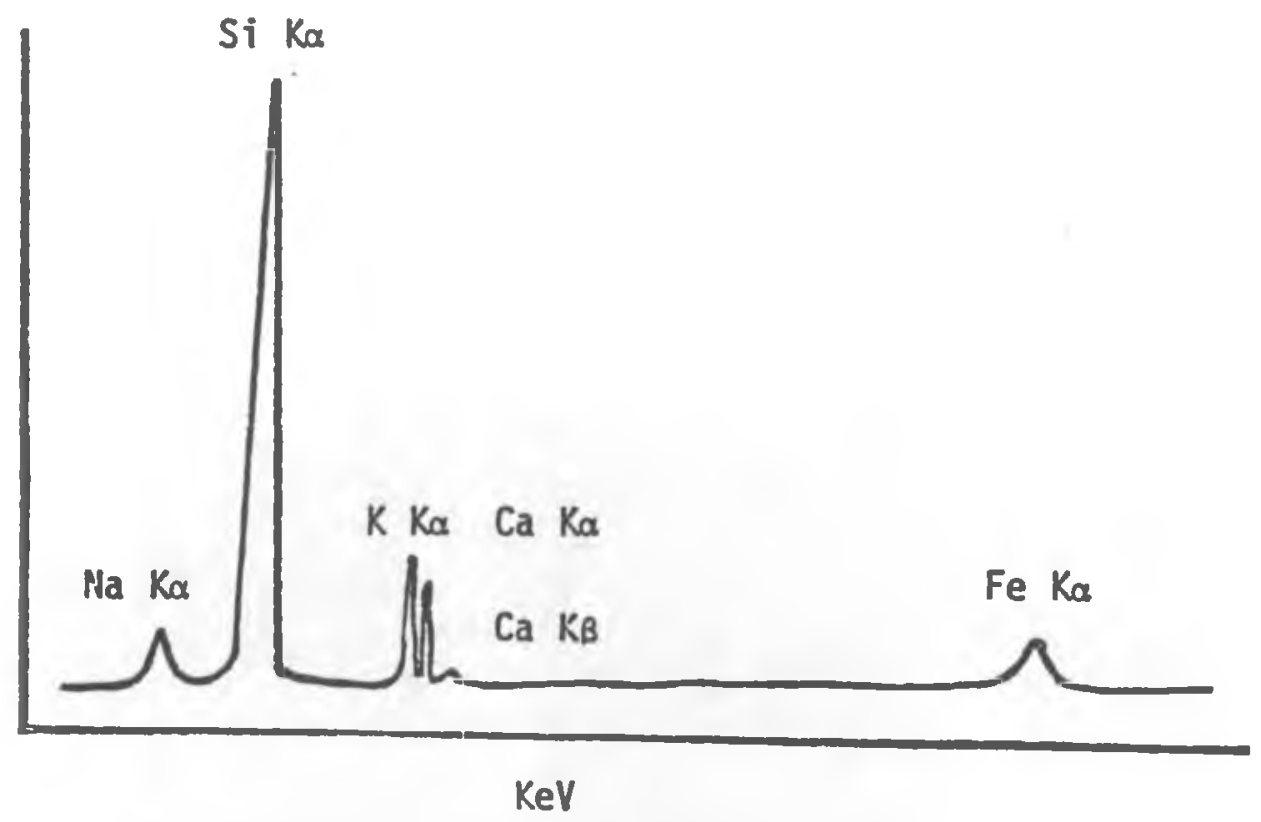

(b) EDX chemistry for the rosette crystals.

FIG. 6.14 


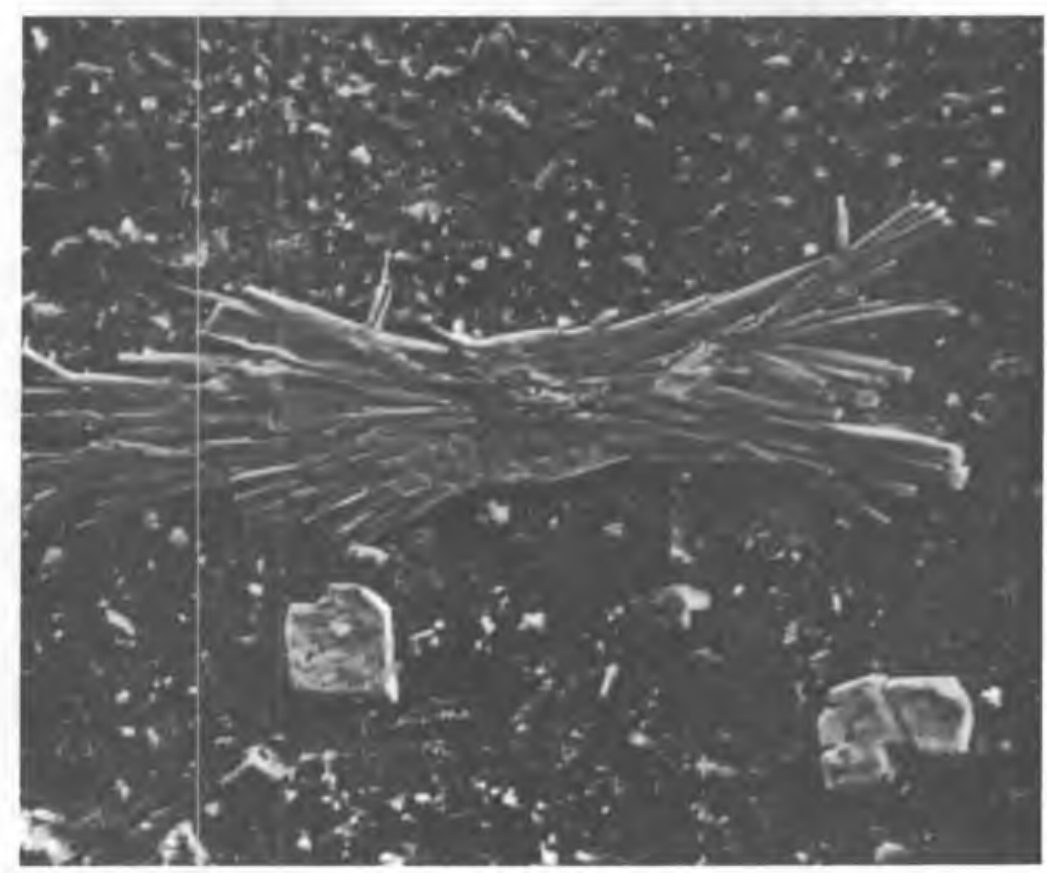

FIG. 6.15 Crystal development of a Zn, Si-rich phase $200 \mu \mathrm{m}$ in maximum dimension on the surface of a glass plus DDH-3 mixture hydrothermally treated under low water (type C) conditions at $400^{\circ} \mathrm{C}$.

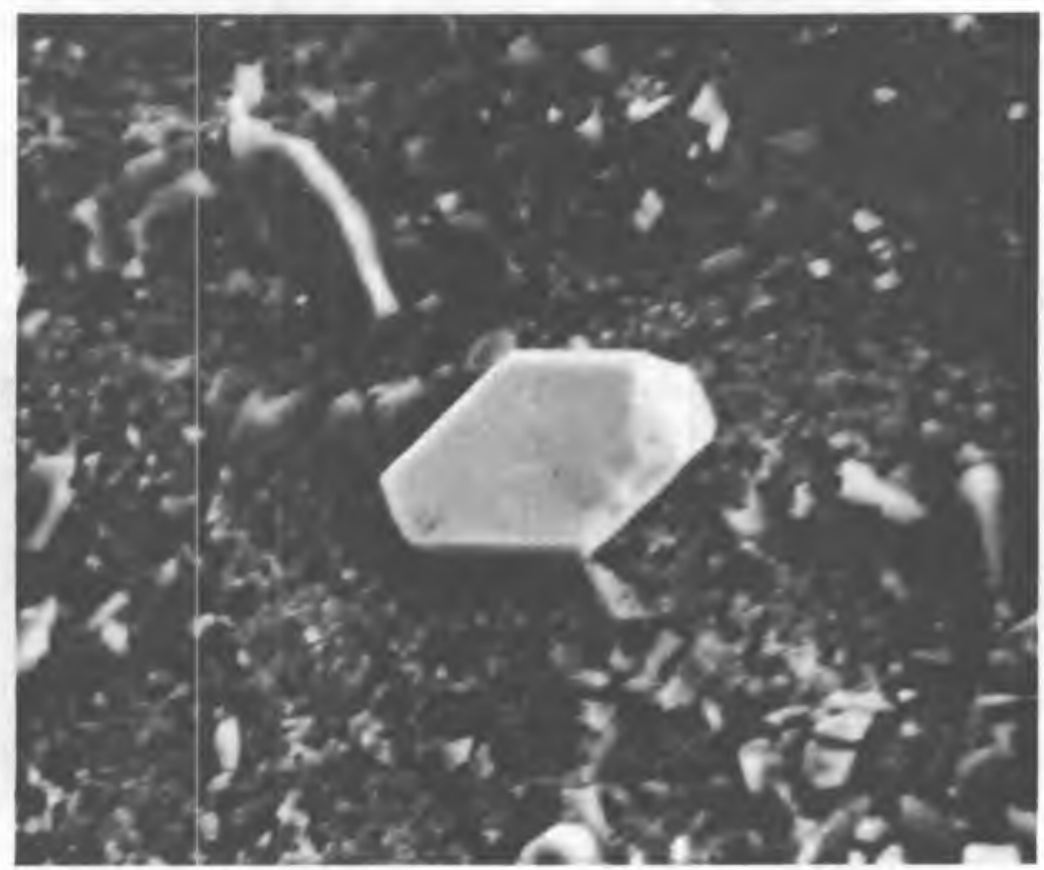

FIG. 6.16 Euhedral crystal of what is possibly a scheelite structure phase rich in $\mathrm{Ba}$ and Mo that developed on surface of glass and $\mathrm{DDH}-3$ hydrothermally treated at $400^{\circ} \mathrm{C}$. 
- The basalts alone showed little or no alterations under the 30-day hydrothermal treatments. However, when calcine was present, the system proved to be quite reactive. The ubiquitous presence of pollucite in all calcine/basalt products suggests the $C_{s}$ is an especially mineralizing species toward basalt.

- Simulated waste glass 76-68 reacts rapidly under hydrothermal conditions at temperatures as $10 \mathrm{w}$ as $200^{\circ} \mathrm{C}$, the lowest temperature studied to date. The identification of quartz crystals as an interaction product suggests extensive breakdown of the silicate glass followed by nucleation and crystallization of less soluble constituents.

- So far, the breakdown of the glass seems to lead to the same crystalline phases whether or not the hydrothermal solutions are in contact with basalt. We believe that this will not be the case in longer-term treatments; i.e., that the Eh-pH conditions established by the large excess of basalt in contact with the solutions will promote different modes of glasssolutions interactions and that the species dissolved from the glass will react with basalt, albeit more slowly than in the case of calcine, to form such phases as pollucite.

- The crystalline waste form, supercalcine, has been quite stable in the hydrothermal experiments conducted so far. It may take much longer treatments to begin to see any substantial alteration in its mineralogy. Some of its phases; e.g., pollucite, monazite, apatite, scheelite, may prove to be in stable equilibrium under these relevant hydrothermal conditions.

- The $\mathrm{UO}_{2}$ component of SURF has not yet shown substantial interactions in the hydrothermal experiments conducted to date. He fully expect that the minor, but in some cases water soluble, fission product components of SURF will prove to have been quite reactive when we initiate detailed characterization of these reconnaissance experiments in early FY 1978.

- The identity of phases formed by the calcine/basalt and glass/ ground water interactions is very important because if there were to be waste/rock interactions during the thermal period, these phases would be the actual "source-terms" for long-term nuclide migration studies, not the calcine or glass itself. Therefore, we will be making every effort to identify the phases in which Cs, $\mathrm{Sr}$ and $\mathrm{U}$ (as a model for $\mathrm{Np}$ and $\mathrm{Pu}$ ) crystallize in the coming year. 


\section{APPENDIX A}

Hanford Ground Water Formulation

An inquiry into the best available data on the water chemistry for the Umtanum formation produced the data supplied by $\mathrm{Mr}$. L. L. Ames, BattelleNorthwest, in 1976. The closest formation on which data were available was the lower confined aquifer designated the lower Yakima basalts. The age of this formation has been determined to be 13,000 years before present. The analys is presented is as follows.

\begin{tabular}{lc} 
Ionic Species & Concentration (Parts Per Million) \\
\cline { 1 - 2 } & 168.0 \\
$\mathrm{Ca}$ & 0.5 \\
$\mathrm{Mg}$ & 0.1 \\
$\mathrm{Cl}$ & 90.0 \\
$\mathrm{SO}_{4}$ & 14.0 \\
$\mathrm{HCO}_{3}$ & 56.0 \\
$\mathrm{CO}_{3}$ & 87.0 \\
$\mathrm{~K}^{2}$ & 4.0 \\
$\mathrm{Hardness}$ & 2.0 \\
$\mathrm{pH}$ & 9.6
\end{tabular}

Two liters of a simulated Hanford ground water were prepared from standard reagent grade chemicals using the following concentrations.

\begin{tabular}{lr} 
Reagent & \multicolumn{1}{c}{$\mathrm{mg} / 1$} \\
& 139.9 \\
$\mathrm{CaCl}_{2}$ & 1.4 \\
$\mathrm{MgCl}_{2}$ & 0.4 \\
$\mathrm{KCl}^{2}$ & 7.6 \\
$\mathrm{H}_{2} \mathrm{SO}_{4}$ & 14.3 \\
$\mathrm{NaHCO}_{3}$ & 77.5 \\
$\mathrm{Na}_{2} \mathrm{CO}_{3}$ & 154.8 \\
$\mathrm{HCl}$ & 87.59 \\
$\mathrm{pH}$ & 10.0
\end{tabular}

Since this analysis did not report the silica content, it was decided to place a quantity of a high-surface-area amorphous silica into the solution in order to saturate it with respect to silicon. 
APPENDIX C

Run Tables for Reconnaissance

Types A, C, and D Experiments 
RUN TABLE NO.

\begin{tabular}{|c|c|c|c|c|c|}
\hline \multicolumn{5}{|c|}{$\begin{array}{l}\square \text { DRY (Type A) } \\
\square \text { HYDROTHERMAL - LOW HATER (Type C) } \\
\square \text { HYOROTHERMAL - HIGH HATER (Type D) }\end{array}$} & \multirow{2}{*}{$\frac{\frac{\text { TEMPERATURE: }}{\text { DURATION: } \frac{200}{42}{ }^{\circ} \text { Days }}}{\frac{\text { PRESSURE: }}{\star}{ }^{\text {Psi }}}$} \\
\hline Specimen & code & $\begin{array}{l}\text { Seal } \\
\text { Maintained } \\
\text { During Run }\end{array}$ & $\begin{array}{l}\text { Description of } \\
\text { Reaction Tubes }\end{array}$ & Optical Microscope Observations & \\
\hline 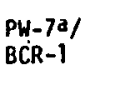 & 20-A & yes & $\begin{array}{l}\text { light devitrification } \\
\text { about pellet }\end{array}$ & no obvious reaction & no appreciable change \\
\hline $\begin{array}{l}76-68 / \\
B C R-1\end{array}$ & 20-B & yes & $\begin{array}{l}\text { light devitrification } \\
\text { about pellet }\end{array}$ & no obvious reaction & $\begin{array}{l}\text { plagioclase peak superimposed } \\
\text { upon glassy cont inuum, some } \\
\text { enhancement of the basalt } \\
\text { peaks; no new observed peaks }\end{array}$ \\
\hline $\begin{array}{l}\mathrm{SPC}-21 \\
B C R-1\end{array}$ & $20-c$ & yes & no devitrification & no obvilous reaction & no appreciable change \\
\hline BCR-1 & 20-0 & yes & $\begin{array}{l}\text { light devitrification } \\
\text { abc } t \text { pellet }\end{array}$ & no obvious reaction & no appreciable change \\
\hline $\begin{array}{l}\text { SURF/ } \\
\text { BER-1 }\end{array}$ & 20-E & yes & no Jevitrification & no obvious reaction & no appreciable change \\
\hline 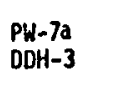 & $20-F$ & yes & light devitrification & no obvilous reaction & $\begin{array}{l}\text { decrease in intensity of } 27.8 \\
\text { scheelite peak relative } \\
\text { to } 28.6 \text { fluorite peak }\end{array}$ \\
\hline $\begin{array}{l}76-68 / \\
D D H-3\end{array}$ & $20-6$ & yes & light devitrification & no obvious reaction & no apparent change \\
\hline
\end{tabular}

*Runs performed in evacuated, sealed silica vials; initial pressure on sealing was torr. 
RUN TABLE NO.

\begin{tabular}{|c|c|c|c|c|c|}
\hline Specimen & Code & \begin{tabular}{|c|} 
Seal \\
Maintained \\
During Run
\end{tabular} & $\begin{array}{l}\text { Description of } \\
\text { Reaction Tubes }\end{array}$ & Optical Microscope Observations & $x$-ray Observations \\
\hline $\begin{array}{l}\mathrm{SPC}-2 / \\
\mathrm{DOH}-3\end{array}$ & $20-H$ & yes & light devitrification & no obvious reaction & \\
\hline DOH-3 & $20-1$ & yes & $\begin{array}{l}\text { light devitrification } \\
\text { about pellet }\end{array}$ & no obvious reaction & $\begin{array}{l}\text { decrease in intensity of minor } \\
\text { peaks relattve to } 100 \mathrm{I} / \mathrm{I}_{0} \\
\text { peak of plagioclase }\end{array}$ \\
\hline $\begin{array}{l}\text { SURF/ } \\
\text { DOH-3 }\end{array}$ & $20-\mathrm{J}$ & yes & $\begin{array}{l}\text { light devitrification } \\
\text { about pellet }\end{array}$ & no obvious reaction & no apparent change \\
\hline PW-7a & $20-k$ & yes & $\begin{array}{l}\text { moderate devitrification } \\
\text { about pellet }\end{array}$ & edges of pellet noticeably darkened & \\
\hline $76-68$ & $20-\mathrm{L}$ & yes & no devitrification & no obvilous reaction & no apparent change \\
\hline SPC-2 & $20-14$ & yes & no devitrification & no obvious reaction & no apparent change \\
\hline SURF & $20-4$ & yes & no devitrification & no obvious reaction & \\
\hline
\end{tabular}


RUN TABLE NO. 3

\begin{tabular}{|c|c|c|c|c|c|}
\hline \multicolumn{5}{|c|}{$\begin{array}{l}{[叉] \text { DRY (Type A) }} \\
\square \text { HYDROTHERMAL - LOW WATER (Type C) } \\
\square \text { HYOROTHERMLL - HIGH WATER (Type D) }\end{array}$} & $\begin{array}{l}\text { TEMPERATURE: } 400{ }^{\circ}{ }^{\circ} \\
\text { DURATION: } 30 \text { Days } \\
\text { PRESSURE: * Psi }\end{array}$ \\
\hline Specimen & code & $\begin{array}{l}\text { Seal } \\
\text { Maintained } \\
\text { During Run }\end{array}$ & $\begin{array}{l}\text { Description of } \\
\text { Reaction Tubes }\end{array}$ & Optical Microscope Observations & $x$-ray observations \\
\hline 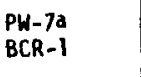 & $21-A$ & yes & & $\begin{array}{l}\text { pellet shows dark gray coloration with light gra: surface } \\
\text { powder }\end{array}$ & complex pattern \\
\hline $\begin{array}{l}76-68 / \\
B C R-1\end{array}$ & $21-8$ & yes & & no obvious reaction & complex pattern \\
\hline $\begin{array}{l}\text { SPC-2/ } \\
\text { BCR-1 }\end{array}$ & $21-c$ & yes & & no obvious reaction & \\
\hline BCR-1 & $21-0$ & yes & & no obvious reaction & no apparent change \\
\hline $\begin{array}{l}\text { SURF } 1 \\
\text { BCR-1 }\end{array}$ & $21-E$ & yes & & no obvious reaction & no apparent change \\
\hline $\begin{array}{l}\text { PH-7a/ } \\
\text { DOH-3 }\end{array}$ & $21-F$ & yes & $\begin{array}{l}\text { heavy devitrifization } \\
\text { about pellet }\end{array}$ & pellet covered with loose, light gray ponder & complex pattern \\
\hline $\begin{array}{l}76-68 / \\
D D H-3\end{array}$ & $21-6$ & yes & & no obvious reaction & no apparent change \\
\hline
\end{tabular}




\begin{tabular}{|c|c|c|c|c|c|}
\hline & $\begin{array}{l}\text { DRY (TY } \\
\text { HYOROTH } \\
\text { HYOROTH }\end{array}$ & $\begin{array}{l}\text { A) } \\
\text { PMAL - LOW WI } \\
\text { PMAL - HIGH }\end{array}$ & $\begin{array}{l}\text { ER (Type C) } \\
\text { TER (Type D) }\end{array}$ & & $\begin{array}{l}\text { IEAPERATURE: } 400 \text { OC } \\
\text { DURATION: } 30 \text { Days } \\
\text { PRESSURE: } * \text { psi }\end{array}$ \\
\hline Specimen & Code & $\begin{array}{l}\text { Seal } \\
\text { Maintalned } \\
\text { During Run }\end{array}$ & $\begin{array}{l}\text { Description of } \\
\text { Reaction Tubes }\end{array}$ & Optical Microscope Observations & $x$-ray observations \\
\hline $\begin{array}{l}\mathrm{SPC}-2 \mathrm{I} \\
\mathrm{DOH}-3\end{array}$ & $21-4$ & yes & & no obvious reaction & no apparent change \\
\hline DOH-3 & $21-1$ & yes & & no obvious reaction & no apparent change \\
\hline $\begin{array}{l}\text { SURF/ } \\
\text { DOH }-3\end{array}$ & $21-3$ & yes & & no obvious reaction & no apparent change \\
\hline$P W-7 a$ & $21-k$ & no & & pellet surface covered with needle crystals & \\
\hline $76-68$ & 21-L & yes & & Pt spacer tarnished; no obvious reaction & \\
\hline SPC-2 & $27-M$ & yes & $\begin{array}{l}\text { moderate devitrification } \\
\text { above buffer }\end{array}$ & no obvious reaction & no apparent change \\
\hline SURF & $21-\mathrm{N}$ & yes & $\begin{array}{l}\text { moderate devitriftcatinn } \\
\text { about pellet }\end{array}$ & no obvious reaction & no appreciable change \\
\hline
\end{tabular}


RUN TABLE NO. 5

X] ORY (Type A)

$\square$ HYDROTHEPMAL - LOW MATER (TYPE C)

$\square$ HYOROTHERMAL - HIGH UATER (Type D)

TEMPERATURE: 400 OC

DURATION: 30 Days

PRESSURE: $*$ PSI

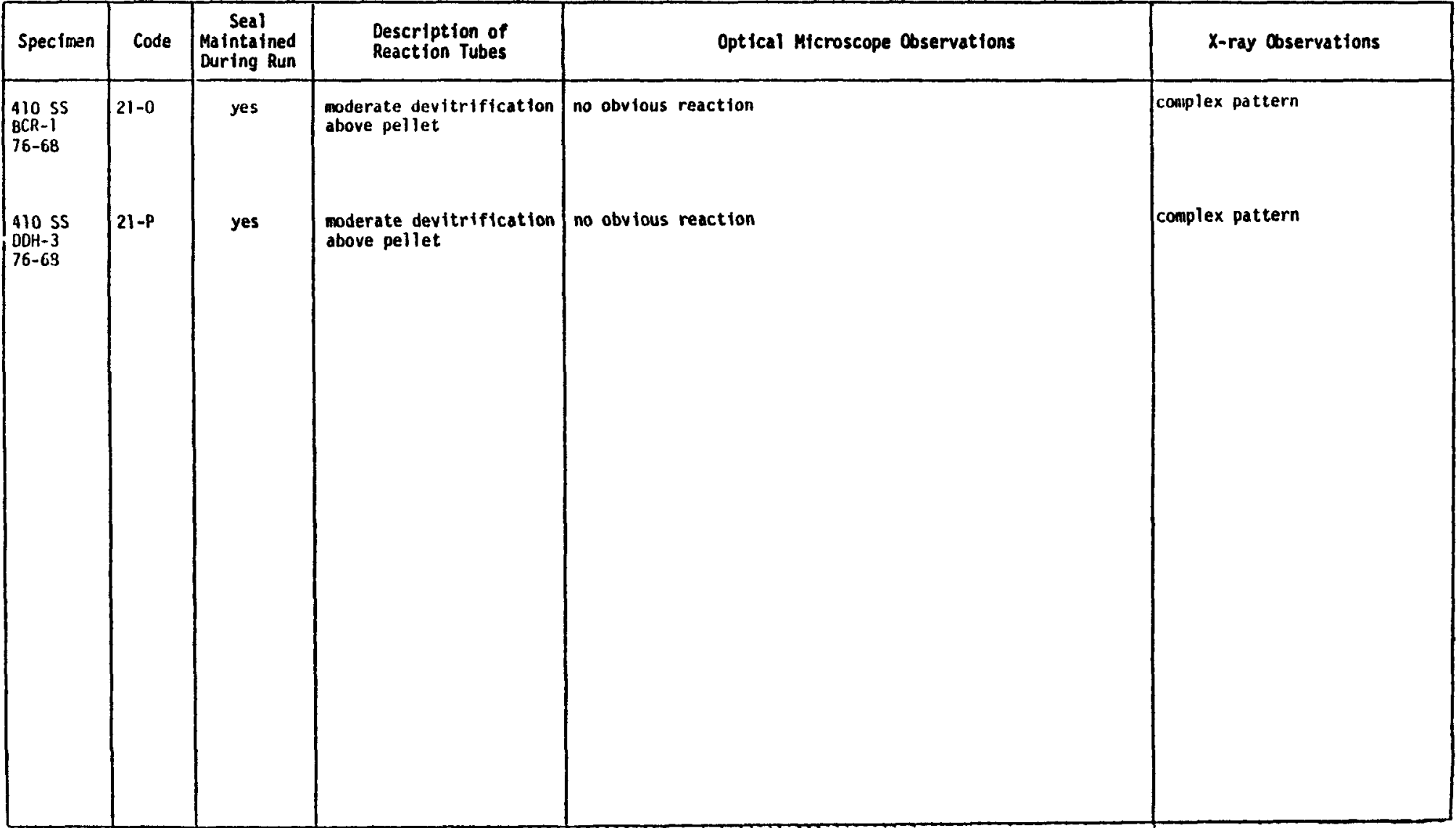


RUN TABLE NO, 6

\begin{tabular}{|c|c|c|c|c|c|}
\hline Specimen & Code & $\begin{array}{c}\text { Seal } \\
\text { Maintalned } \\
\text { During Run }\end{array}$ & $\begin{array}{l}\text { Description of } \\
\text { Reaction Tubes }\end{array}$ & Optical Microscope Observations & $x$-ray Observations \\
\hline $\begin{array}{l}\text { PW-7a/ } \\
B C R-1\end{array}$ & $25-\mathrm{A}-2$ & yes & $\begin{array}{l}\text { devitrification about } \\
\text { pellet }\end{array}$ & surface of pellet sugaryi some needle crystals (very few) & \\
\hline $\begin{array}{l}76-68 / \\
B C R-1\end{array}$ & $25-8-2$ & yes & $\begin{array}{l}\text { devitrification about } \\
\text { pellet }\end{array}$ & sintered appearance, pock-marked surface & \\
\hline $\begin{array}{l}\text { SPC-2/ } \\
B C R-1\end{array}$ & $25-c-2$ & yes & Iight devitrification & no obvious reaction & \\
\hline BCR-1 & $25-0-2$ & yes & light devitrification & no obvious reaction & \\
\hline $\begin{array}{l}\text { SURF/ } \\
B C R-1\end{array}$ & $25-E-2$ & yes & light devitrification & no obvious reaction & \\
\hline $\begin{array}{l}\mathrm{PH}-7 \mathrm{a} / \mathrm{I} \\
\mathrm{DOH}-3\end{array}$ & $25-F-2$ & yes & $\begin{array}{l}\text { devitrification about } \\
\text { pellet }\end{array}$ & $\begin{array}{l}\text { substantial needle growth in sugary coating, a few radial } \\
\text { white clusters }\end{array}$ & \\
\hline $\begin{array}{l}76-68 / \\
\mathrm{DOH}-3\end{array}$ & $25-6-2$ & yes & heavy devitrification & $\begin{array}{l}\text { three clinkers of broken pellet sintered together; surface } \\
\text { appears pock-marked }\end{array}$ & $\begin{array}{l}\text { loss of intensity of main } \\
\text { plagioclase peak; substantial } \\
\text { broadening of this peak as } \\
\text { well i; loss of intensity of most } \\
\text { of the minor plagioclase peaks. } \\
\text { except for the one at } 29.8\end{array}$ \\
\hline $\begin{array}{l}\mathrm{SPC}-2 / \\
\mathrm{ONH}-3\end{array}$ & $25-H-2$ & yes & $\begin{array}{l}\text { light devitrification } \\
\text { about nellet }\end{array}$ & no obvious reaction & no apparent change \\
\hline
\end{tabular}


RUN TABLE NO.

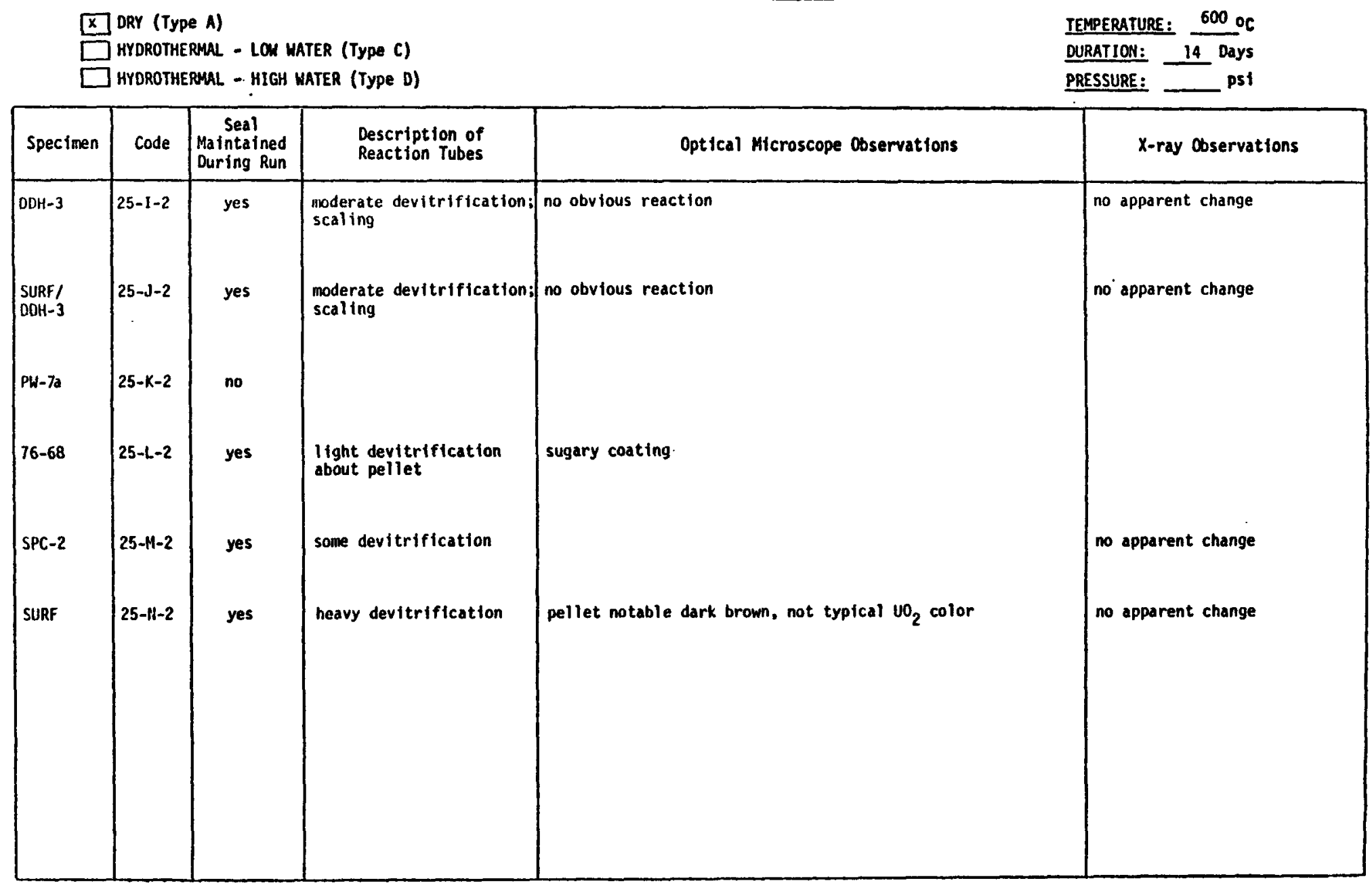


RUN TABLE NO.

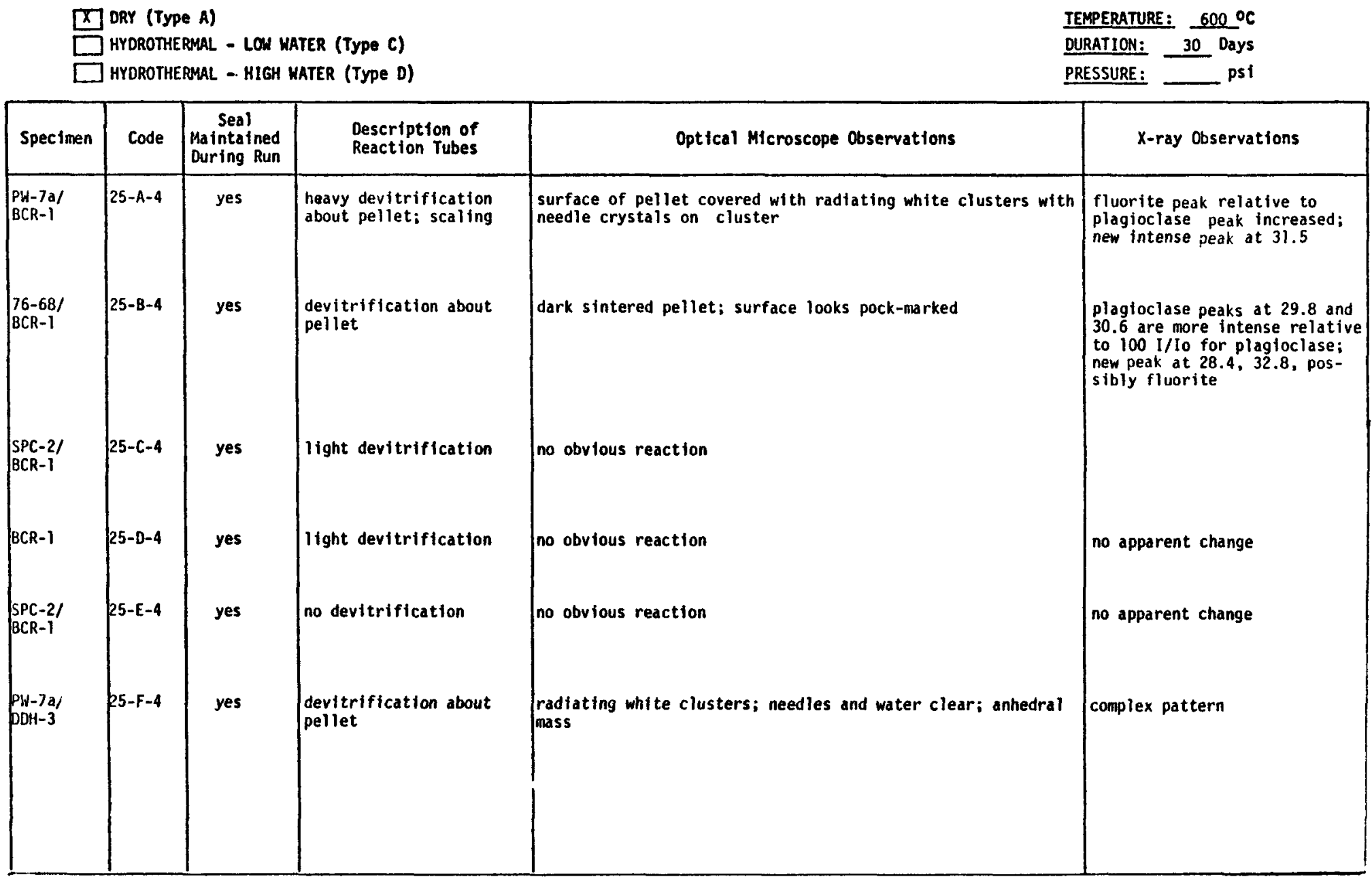


RUN TABLE NO.

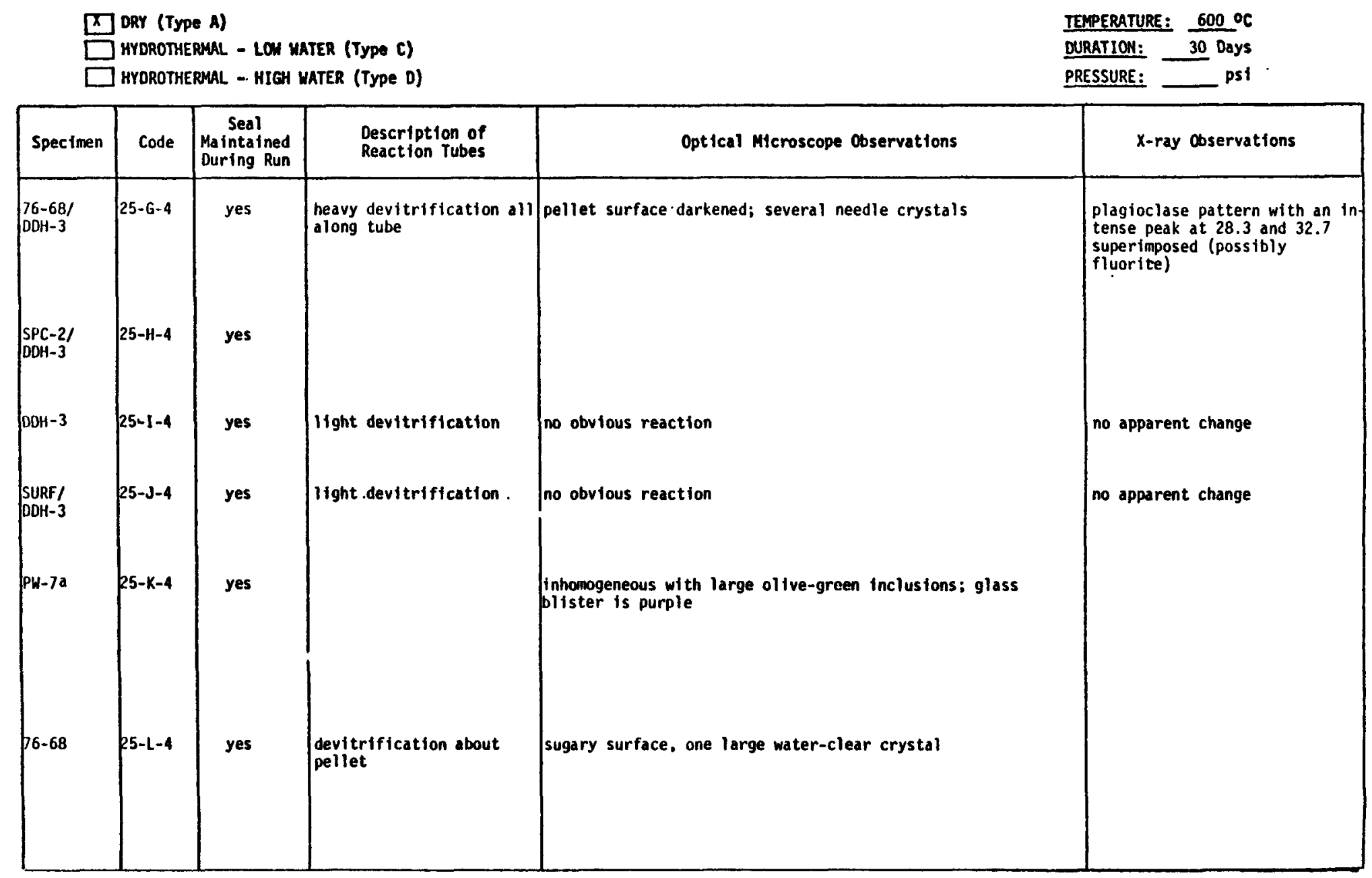


RUN TABLE NO.

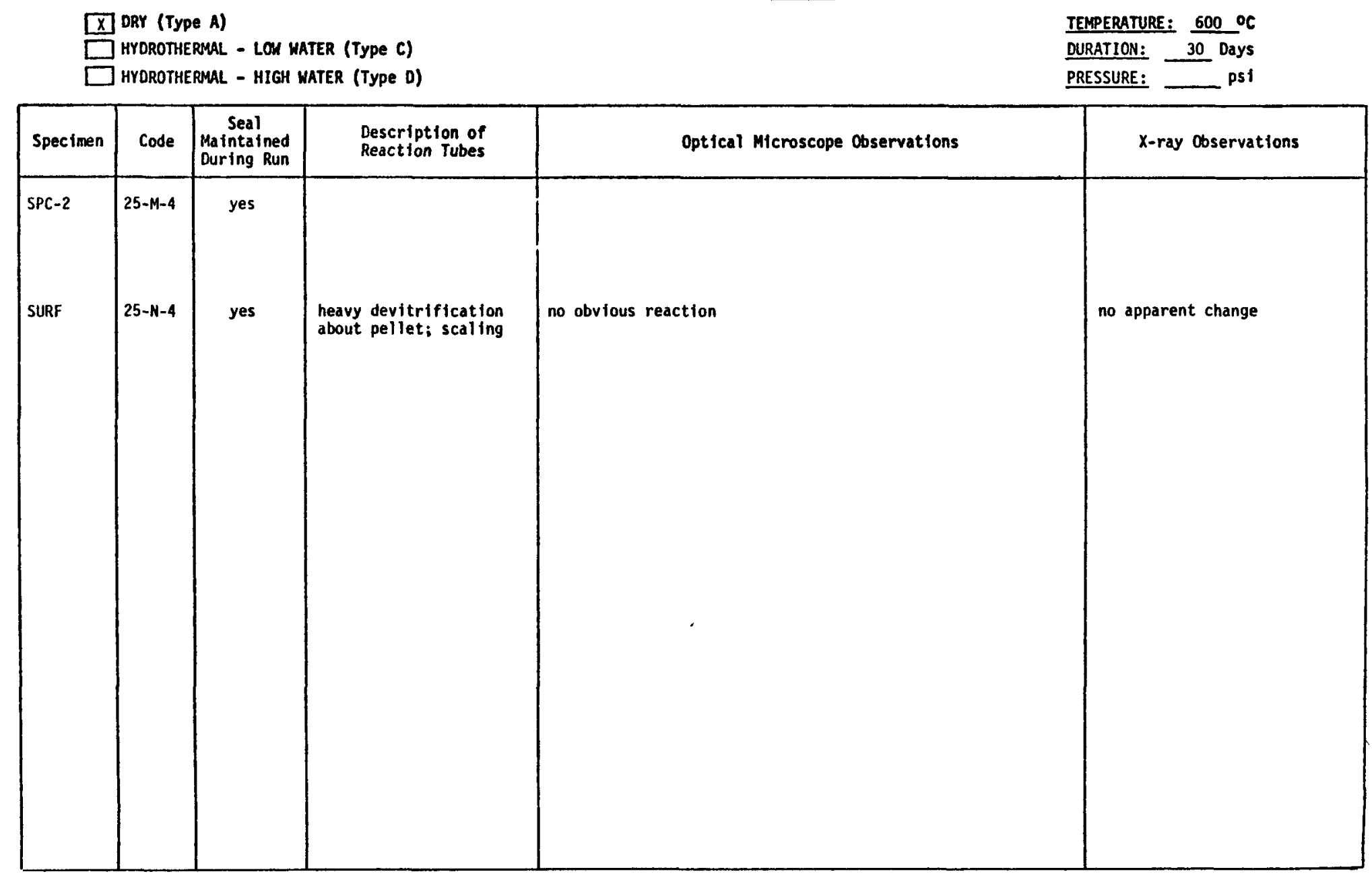


RUN TABLE NO.

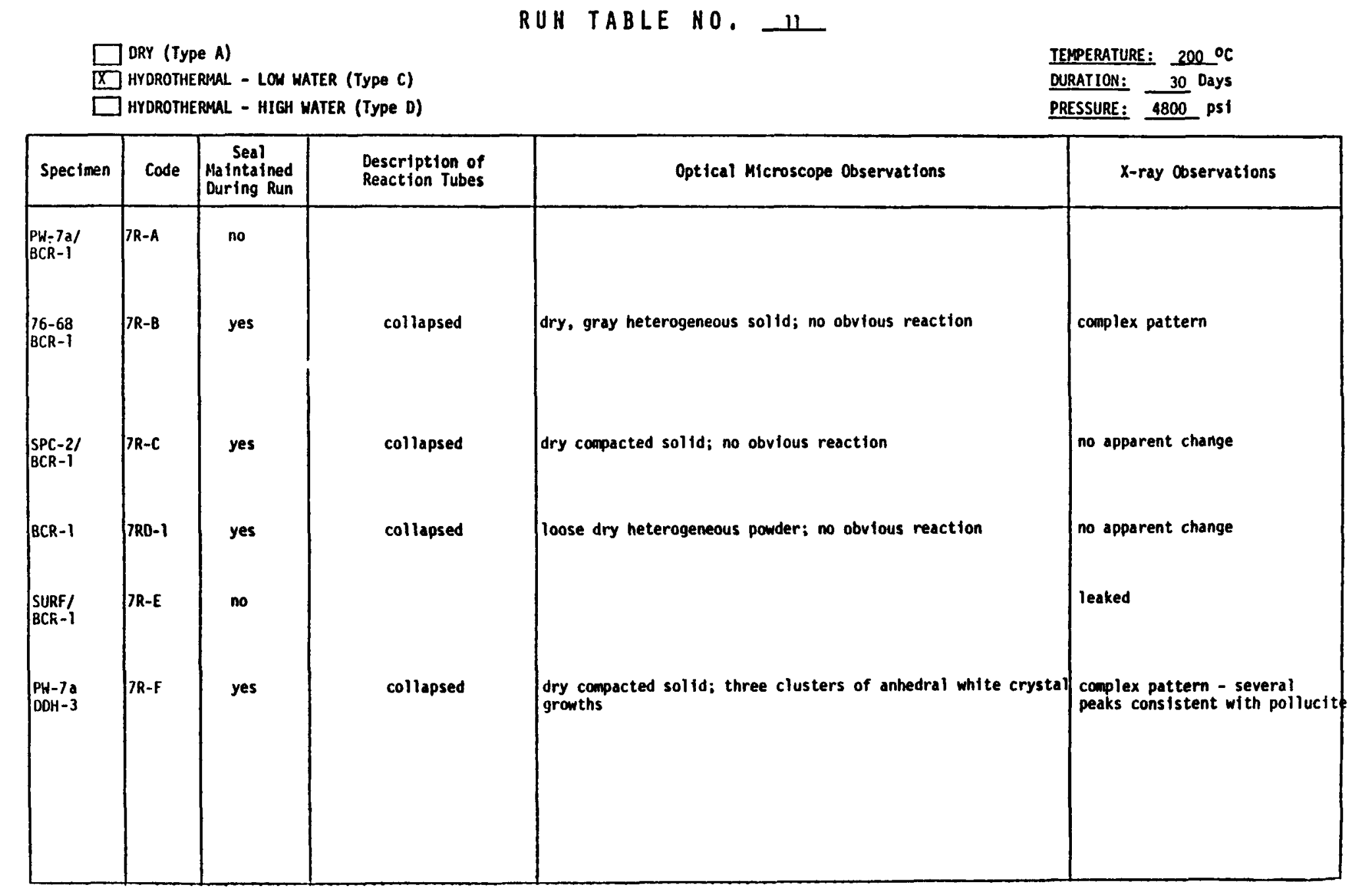


RUN TABLE NO, 12

\begin{tabular}{|c|c|c|c|c|c|}
\hline \multicolumn{4}{|c|}{$\begin{array}{l}\square \text { ORY (Type A) } \\
\square \text { HYOROTHERMAL - LOU WATER (Type C) } \\
\square \text { HYDROTHERMAL - HIGH WATER (Type D) }\end{array}$} & \multicolumn{2}{|c|}{ 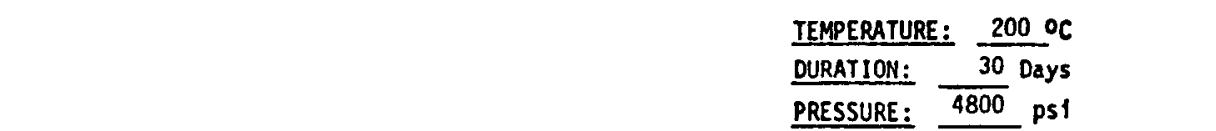 } \\
\hline Specimen & Code & \begin{tabular}{|c|} 
Seal \\
Maintained \\
During Run
\end{tabular} & $\begin{array}{l}\text { Description of } \\
\text { Reaction Tubes }\end{array}$ & Optical Microscope Observations & $x$-ray observations \\
\hline $\begin{array}{l}76-68 / \\
\mathrm{OOH}-3\end{array}$ & $7 R-6$ & no & & & leaked \\
\hline $\begin{array}{l}\mathrm{SPC}-2 / \\
\mathrm{DOH}-3\end{array}$ & $7 R-H$ & yes & collapsed & Toose, dry, gray powder; no obvious reaction & no apparent change \\
\hline DOH-3 & $7 R-1$ & yes & collapsed & loose dry gray powder: no obvious reaction; asphalt-like odor & no apparent change \\
\hline $\begin{array}{l}\text { SURF } / \\
\text { ODH-3 }\end{array}$ & $7 R-J$ & yes & collapsed & dry lump, compacted solid & no apparent change \\
\hline PH-7a & $7 R-k$ & yes & collapsed & $\begin{array}{l}\text { surface has dark glassy-looking patches which may be small } \\
\text { crystal masses }\end{array}$ & \\
\hline $76-68$ & $7 R-L$ & yes & collapsed & partially compacted heterogeneous light gray solid & $\begin{array}{l}\text { mostly amorohous pattern } \\
\text { several indications of fluor- } \\
\text { tte } 28.8 \text { ond fe-spinels at } \\
35.5\end{array}$ \\
\hline $\mathrm{SPC}-2$ & $7 R-M$ & no & & & leaked \\
\hline
\end{tabular}


RUN TABLE NO,

$\square$ DRY (Type A)

$\square$ HYDROTHERMAL - LOW HATER (Type C)

$\square$ HYDROTHERMAL - HIGH WATER (TYPe O)

TEMPERATURE; 200 OC

DURATION: 30 DaYs

PRESSURE: 4800 pS1

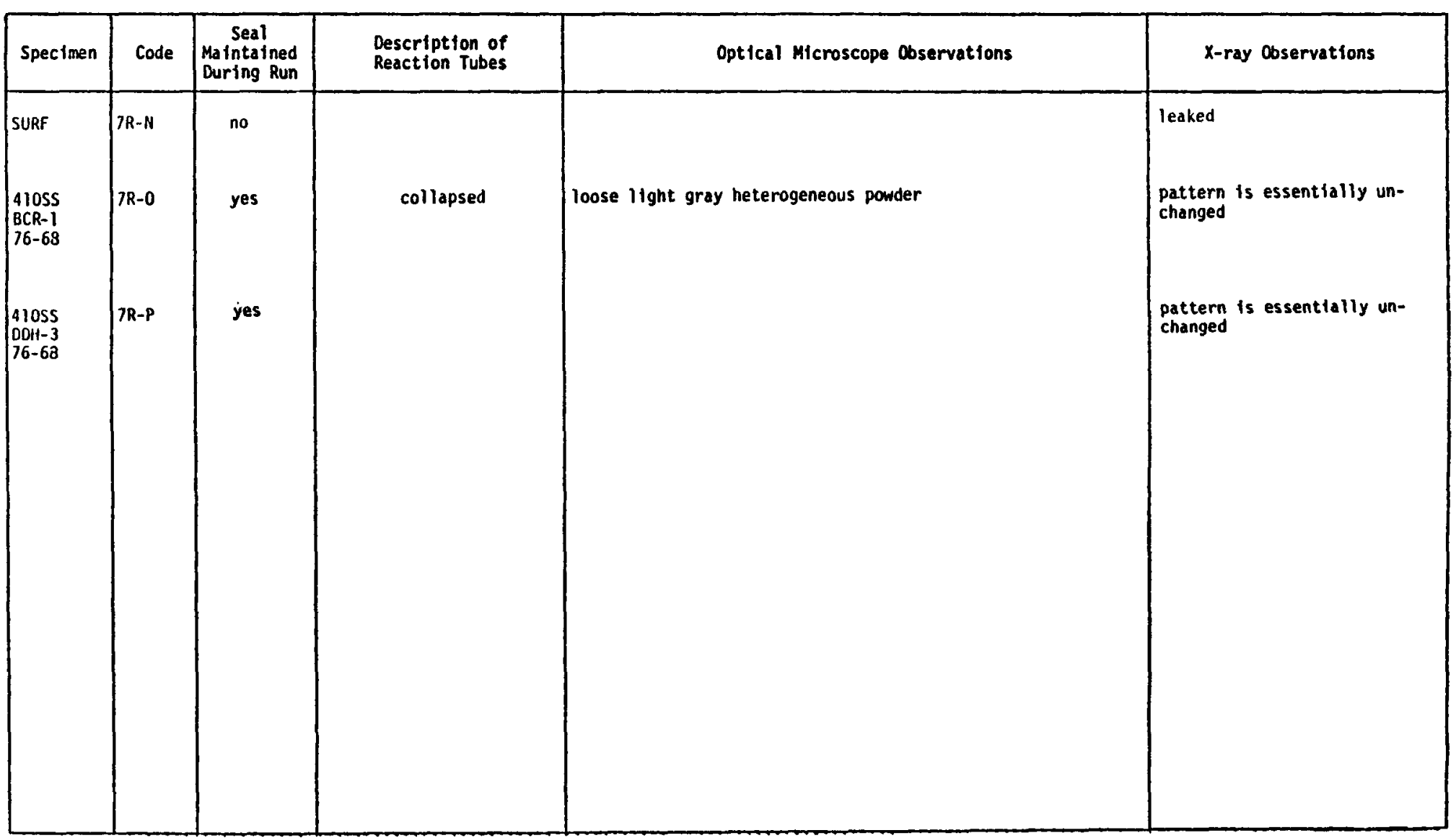


RUN TABLE NO.

TEMPERATURE: 400 OC

DURATION: 30 Days

PRESSURE: 4000 PSI

\begin{tabular}{|c|c|c|c|c|c|}
\hline Specimen & Code & $\begin{array}{l}\text { Seal } \\
\text { Maintained } \\
\text { During Run }\end{array}$ & $\begin{array}{l}\text { Description of } \\
\text { Reaction Tubes }\end{array}$ & Optical Microscope Observations & $x$-ray Observations \\
\hline $\begin{array}{l}\text { PW-7ad } \\
\text { BCRI }\end{array}$ & $6 R-A$ & yes & expanded & $\begin{array}{l}\text { dry, compacted solid; surface is completely covered with } \\
\text { colorless, euhedral, needle crystals }\end{array}$ & $\begin{array}{l}\text { complex pattern - some peaks } \\
\text { consistent with pollucite }\end{array}$ \\
\hline $\begin{array}{l}76-68 / \\
B C R 1\end{array}$ & $6 R-B$ & yes & collapsed & $\begin{array}{l}\text { dry, compacted sol id; surface has three crystal types: } \\
\text { (a) colorless, needles; (b) black radiating clusters: } \\
\text { (c) large colorless rossette }\end{array}$ & no apparent change \\
\hline $\begin{array}{l}\text { SPC-2I } \\
B C R 1\end{array}$ & $6 R-C$ & yes & collapsed & $\begin{array}{l}\text { dry heterogeneous gray powder; powder adhered to Au tube } \\
\text { wall }\end{array}$ & no apparent change \\
\hline BCR1 & GR-DT & yes & expanded & $\begin{array}{l}\text { audible pressure release; sweet petroleum distlllate odor; } \\
\text { no obvious reaction }\end{array}$ & no apparent change \\
\hline $\begin{array}{l}\text { SURFI } \\
\text { BCRI }\end{array}$ & GR-EI & no & & & \\
\hline $\begin{array}{l}\mathrm{PH}-7 \mathrm{aI} \\
\mathrm{DDH}-3\end{array}$ & $6 R-F$ & no & collapsed & extensive needle growth just on upper surface; needles solid & $\begin{array}{l}\text { Complex pattern - some peaks } \\
\text { consistent with pollucite }\end{array}$ \\
\hline
\end{tabular}


RUN TABLE NO, 15

\begin{tabular}{|c|c|c|c|c|c|}
\hline \multicolumn{5}{|c|}{$\begin{array}{l}\square \text { DRY (Type A) } \\
\square \text { HYOROTHERSAL - LOW WATER (Type C) } \\
\square \text { HYDROTHERMAL - HIGH WATER (Type D) }\end{array}$} & $\begin{array}{l}\text { TEMPERATURE: } \frac{400 \text { o }}{30} \\
\text { DURATION: } \frac{30}{30} \text { Days } \\
\text { PRESSURE: } \frac{4000}{4051}\end{array}$ \\
\hline Specimen & Code & $\begin{array}{l}\text { Seal } \\
\text { Maintained } \\
\text { During Run }\end{array}$ & $\begin{array}{l}\text { Description of } \\
\text { Reaction Tubes }\end{array}$ & Optical Microscope Observations & $x$-ray Observations \\
\hline $\begin{array}{l}76-68 / \\
0 \mathrm{OH3}\end{array}$ & $6 R-G$ & yes & collapsed & $\begin{array}{l}\text { dry, compacted solid; surface covered with colorless needle } \\
\text { crystals and black radiating clusters }\end{array}$ & $\begin{array}{l}\text { relative intensities remain } \\
\text { unchanged among intense peaks; } \\
\text { overall intensity seems } \\
\text { diminished; no new peaks }\end{array}$ \\
\hline $\begin{array}{l}\mathrm{SPC}-21 \\
\mathrm{DOH}-3\end{array}$ & $6 R-H$ & yes & collapsed & $\begin{array}{l}\text { Ary, compacted, uniform; gray solid; no obvious reactions; } \\
\text { strong petroleum distiliate odor }\end{array}$ & no apparent change \\
\hline $\mathrm{DOH} 3$ & $6 R-1$ & yes & collapsed & dry, compacted solid & no apparent change \\
\hline $\begin{array}{l}\text { SURF/ } \\
\text { DOH3 }\end{array}$ & $6 R-J$ & yes & collapsed & dry, compacted solid; faint petroleum distlllate odor & no apparent change \\
\hline PU-7a & $6 R-k$ & yes & collapsed & $\begin{array}{l}\text { dry friable solid; surface was white } 11 \text { near crystal aggre- } \\
\text { gates; surface and interior has yellow buff grains; surface } \\
\text { has patches colored steel-blue }\end{array}$ & \\
\hline $76-68$ & $6 R-1$ & no & & & \\
\hline
\end{tabular}


RUN TABLE NO.

16

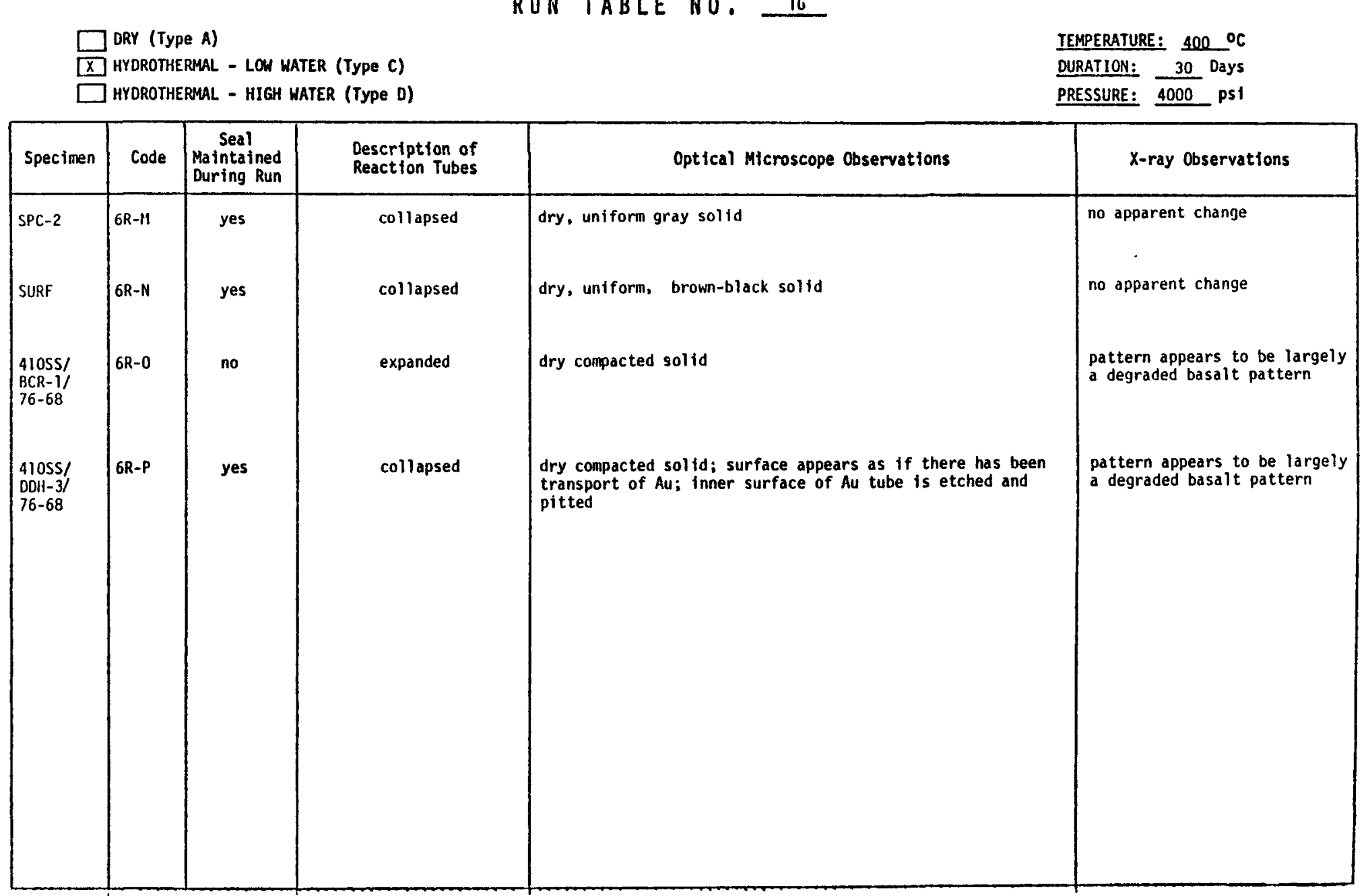


RUN TABLE NO, 17

\begin{tabular}{|c|c|c|c|c|c|}
\hline \multicolumn{4}{|c|}{$\begin{array}{l}\square \text { ORY (Type A) } \\
\square \text { HYOROTHERMAL - LOW WATER (Type C) } \\
\square \text { HYOROTHERMAL - HIGH MATER (Type D) }\end{array}$} & \multicolumn{2}{|c|}{$\begin{array}{l}\text { TEMPERATURE: } \frac{200 \text { OC }}{30} \text { Days } \\
\text { DURATION: } \\
\text { PRESSURE: } \frac{4000 \text { Psi }}{4000}\end{array}$} \\
\hline Specimen & code & $\begin{array}{l}\text { Seal } \\
\text { Maintained } \\
\text { During Run }\end{array}$ & $\begin{array}{l}\text { Descript ton of } \\
\text { Reaction Tubes }\end{array}$ & Optical Microscope Observations & $x$-ray Coservations \\
\hline $\begin{array}{l}\text { PIY-7a/ } \\
\text { BCR-1 }\end{array}$ & $11 R-A$ & yes & unchanged & wet black powder; colorless euhedral crystals on Au tube & $\begin{array}{l}\text { Complex pattern - several } \\
\text { peaks consistent with polluc- } \\
\text { ite }\end{array}$ \\
\hline $\begin{array}{l}76-68 / \\
B C R^{-1}\end{array}$ & $118-8$ & yes & collapsed & wet. mult tiphase powder & Complex pattern \\
\hline $\begin{array}{l}\mathrm{SPC}-2 / \\
\mathrm{BCR}-1\end{array}$ & IIR-C & yes & unchanged & $\begin{array}{l}\text { wet unt form gray powder; colorless crystal clusters on solid } \\
\text { surface }\end{array}$ & mostly unchanged \\
\hline BCR-1 & IIR-D & no & & & \\
\hline $\begin{array}{l}\text { SURF/ } \\
\text { BCR-1 }\end{array}$ & IIR-E & yes & collapsed & $\begin{array}{l}\text { wet, red-brom, sol id colorless crystal clusters on solid } \\
\text { surface }\end{array}$ & $\begin{array}{l}\text { fluorite peaks unaltered; new } \\
\text { peaks at } 23.6 \text { and } 30.4 ; \text { peak } \\
\text { at } 27.2 \text { has disappeared }\end{array}$ \\
\hline $\begin{array}{l}\text { Py-7a/ } \\
\text { DOH-3 }\end{array}$ & $11 R-F$ & yes & unchanged & $\begin{array}{l}\text { wet dark gray solid; inner surface of tube and solid covered } \\
\text { with colorless euhedral blades }\end{array}$ & $\begin{array}{l}\text { Complex pattern - several } \\
\text { peaks consistent with polluc- } \\
\text { ite }\end{array}$ \\
\hline
\end{tabular}


RUN TABLE NO, 18

$\square$ DRY (Type A)

HYDROTHERMAL - LON WATER (TyPE C)

[Q HYOROTHERMAL - HIGH WATER (TYPE O)

200 OC

DURATION: 30 Days

PRESSURE: 4000 PSi

\begin{tabular}{|c|c|c|c|c|c|}
\hline Specimen & Code & $\begin{array}{l}\text { Seal } \\
\text { Maintained } \\
\text { During Run }\end{array}$ & $\begin{array}{l}\text { Description of } \\
\text { Reaction Tubes }\end{array}$ & Optical Microscope Observations & $X$-ray Observations \\
\hline $\begin{array}{l}76-68 / \\
\mathrm{DDH}-3\end{array}$ & $11 R-6$ & yes & collapsed & wet compacted dark gray solid & \\
\hline $\begin{array}{l}\mathrm{SPC}-2 / \\
\mathrm{DDH}-3\end{array}$ & $11 R-H$ & yes & collapsed & $\begin{array}{l}\text { wet light gray solid; Inner surface of Au tube has colorless } \\
\text { euhedral crystals }\end{array}$ & no apparent change \\
\hline DDH-3 & IIR-I & yes & unchanged & $\begin{array}{l}\text { strong asphait-like odor; wet dark gray solid; no obvious } \\
\text { reaction }\end{array}$ & no apparent change \\
\hline $\begin{array}{l}\text { SURF/ } \\
\text { ODH -3 }\end{array}$ & $\operatorname{lnR-J}$ & yes & collapsed & wet brown solid; no obvious reaction & no apparent change \\
\hline$P H-7 \mathrm{a}$ & IIR-K & yes & collapsed & $\begin{array}{l}\text { wet compacted solid; surface has emerald green colored } \\
\text { patches with several colorless euhedral crystals }\end{array}$ & $\begin{array}{l}\text { degradation of intensity of } \\
\text { fluorite peak at } 28.8 \text { rela- } \\
\text { tive to scheelite; new peak } \\
\text { at } 26.5\end{array}$ \\
\hline $76-68$ & $11 R-L$ & yes & collapsed & $\begin{array}{l}\text { wet multi-phase sample; colorless euhedral crystals on inner } \\
\text { Au tuhe surface }\end{array}$ & 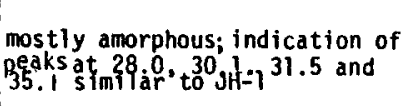 \\
\hline
\end{tabular}


RUN TABLE NO. 19

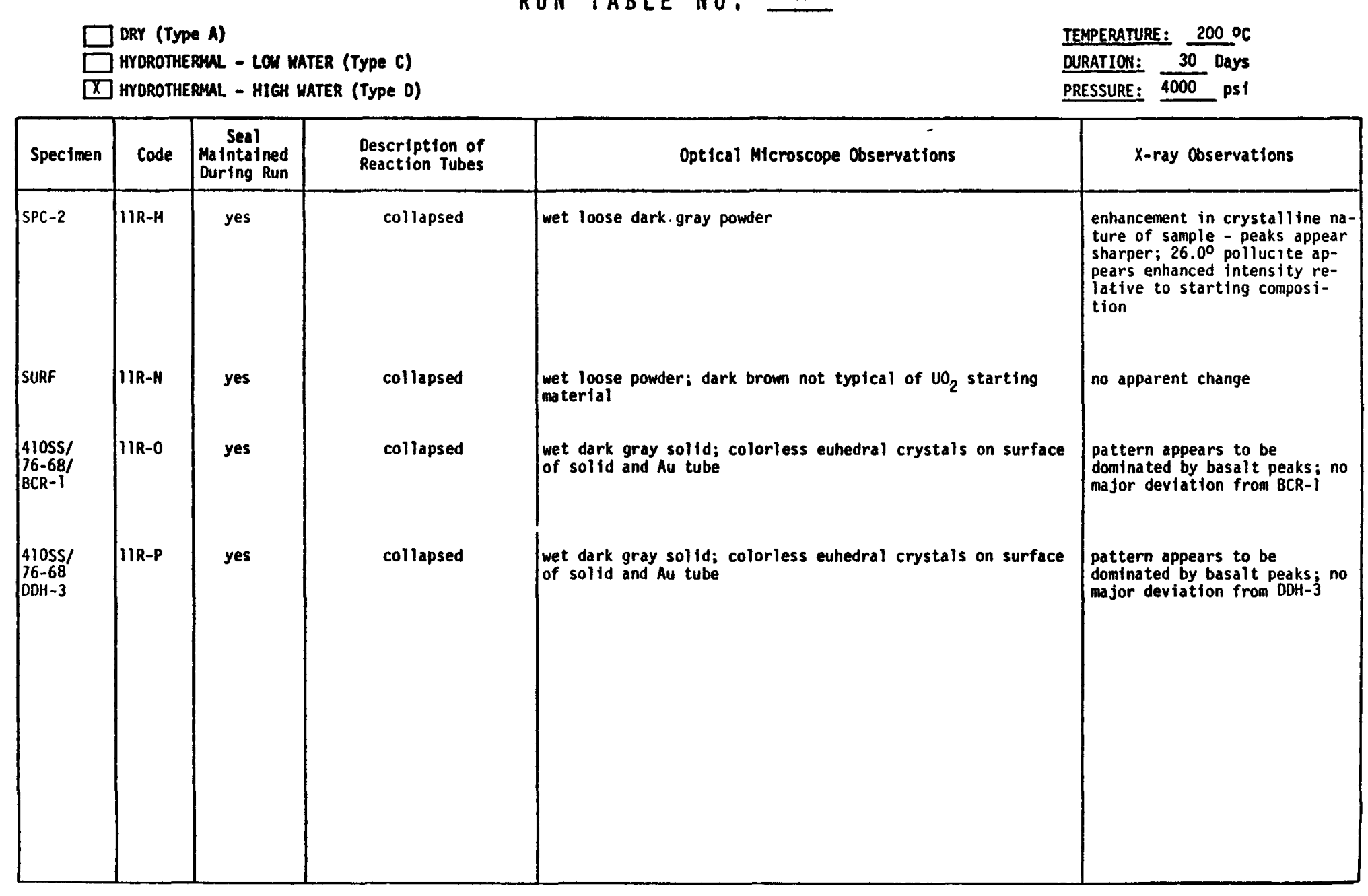


RUN TABLE NO, 20

$\square$ DRY (Type A)

$\square$ HYDROTHERMAL - LOU WATER (TyPe C)

$[\square]$ HYOROTHERMAL - HIGH WATER (TyPe D)

$\frac{\text { IEMPERATURE: }}{\text { DURATION: }} \frac{400 \text { OC }}{30 \text { Days }}$

PRESSURE: 4000 p5i

\begin{tabular}{|c|c|c|c|c|c|}
\hline Specimen & Code & $\begin{array}{l}\text { Seal } \\
\text { Maintained } \\
\text { During Run }\end{array}$ & $\begin{array}{l}\text { Description of } \\
\text { Reaction Tubes }\end{array}$ & Optical Microscope Observations & $x$-ray Observations \\
\hline $\begin{array}{l}P W-7 \mathrm{a} / \\
B C R-1\end{array}$ & $10 R-A$ & yes & expanded & $\begin{array}{l}\text { audible pressure release upon opening tube; wet, uniform, } \\
\text { dark gray compacted solid }\end{array}$ & $\begin{array}{l}\text { fluorite peak at } 28.8^{\circ} \\
\text { relative to plagiociase ana } \\
2 \text { ro still visible; new bands } \\
\text { at } 26.0,26.6,30.5 \text { and } 31.6 \text { - } \\
\text { peaks at } 26.0 \text { and } 30.5 \text { are } \\
\text { consistent with pollucite }\end{array}$ \\
\hline $\begin{array}{l}76-68 / \\
\text { BCR-1 }\end{array}$ & 10R-B & yes & expanded & $\begin{array}{l}\text { petroleum distillate odor upon opening tube; wet solid, } \\
\text { with patch of dark gray mixed with very light gray area at } \\
\text { contact with tube; surface has many euhedral, colorless } \\
\text { crystals (look like quartz) }\end{array}$ & $\begin{array}{l}\text { eight intense peaks, at } 20.1 \text {, } \\
22.1,23.8,24,5,27.9 \\
\text { (scheel ite? } 29.9,30.6 \text { and a } \\
\text { broad peak at } 35.8 ; \text { the } 30.6 \text {, } \\
35.8 \text { may be Fe-5pine); no iden } \\
\text { tification on the others }\end{array}$ \\
\hline $\begin{array}{l}\text { SPC-2I } \\
\text { BCR-1 }\end{array}$ & $10 R-C$ & yes & expanded & $\begin{array}{l}\text { strong petroleum distillate odor upon opening tube; uniform, } \\
\text { wet, dark-gray paste; in open end of tube a water droplet } \\
\text { has white anhedral solid contained in it }\end{array}$ & $\begin{array}{l}\text { no apparent change except } \\
\text { enhanced crystallinity of SPC } \\
\text { peaks }\end{array}$ \\
\hline BCR-1 & IOR-D & no & & & \\
\hline $\begin{array}{l}\text { SURF/ } \\
\text { BCR-I }\end{array}$ & IOR-E & yes & expanded & $\begin{array}{l}\text { audible pressure release upon opening tube; distinct but } \\
\text { weak odor of petroleum distillate; very small anhedral, } \\
\text { colorless crystals; wet, brown (typical } \mathrm{UO}_{2} \text { color) com- } \\
\text { pacted solid }\end{array}$ & $\begin{array}{l}\text { several new peaks at } 22 \\
24.6,29.7,30.3,20.7\end{array}$ \\
\hline
\end{tabular}


RUN TABLE NO.

ORY (Type A)

HYOROTHERMAL - LOW MATER (TyPe C)

[X] HYOROTHERMAL - HIGH WATER (TyPe D)

IEMPERATURE: 400 OC

DURATION: 30 Days

PRESSURE: 4000 psi

\begin{tabular}{|c|c|c|c|c|c|}
\hline Specimen & Code & $\begin{array}{l}\text { Seal } \\
\text { Maintained } \\
\text { During Run }\end{array}$ & $\begin{array}{l}\text { Description of } \\
\text { Reaction Tubes }\end{array}$ & Optical Microscope Observations & $X$-ray Observations \\
\hline $\begin{array}{l}\text { Pid-7a/ } \\
\text { OOH }-3\end{array}$ & hoR-F & yes & expanded & $\begin{array}{l}\text { wet powdery sample: inner surface of Au tube is tarnished } \\
\text { red: open end of tube has: (a) entire surface of powder and } \\
\text { Au tube has small reflecting crystal faces; (b) surface is } \\
\text { covered with yel low spherical aggregates; (c) one colorless } \\
\text { glass"mass with spine protruding from it; (d) small "glassy } \\
\text { mass on Au tube; (e) surface of compacted solid has colorless } \\
\text { euhedral needles }\end{array}$ & $\begin{array}{l}\text { several new peaks at } 22 \text { and } \\
24.6,29.7,30.3,30.7 \text {; the } \\
\text { side peak of the fluorite } \\
\text { band at } 28.3 \text { (27.2) is gone; } \\
\text { relative intensities of peaks } \\
\text { have changed; the peak at } 20.6 \\
\text { is enhanced relative to the } 100 \\
1 / 1 \text { plagioclase peak of basalt } \\
\text { two new very intense peaks ap- } \\
\text { pear at } 26.0^{\circ} \text { and } 30.6^{0} \text {; these } \\
\text { correspond to pollucite }\end{array}$ \\
\hline $\begin{array}{l}76-68 / \\
\mathrm{DOH}-3\end{array}$ & hon-6 & yes & expanded & $\begin{array}{l}\text { strong odor of petroleum distillate; wet, light gray paste; } \\
\text { several large coloriess crystal rosettes on surface; some } \\
\text { appear to be growing at the expense of the solid; inner } \\
\text { surface of Au tube has white scale; colorless crystals are } \\
\text { isotropic with light relief and } n>1.542\end{array}$ & $\begin{array}{l}\text { enhancement in intensity of a } \\
\text { plagioclase peak at } 29.8 \text { with } \\
\text { a shift from } 29.6 \text { to } 29.8 \text { and } \\
30.4 \text { to } 30.6 \text { for two others }\end{array}$ \\
\hline $\begin{array}{l}\text { SPC-2I } \\
\mathrm{DOH}-3\end{array}$ & $12 R-H$ & no & & & \\
\hline $\mathrm{OOH}-3$ & IOR-I & yes & expanded & $\begin{array}{l}\text { heavy petroleum odor; wet paste; inner surface of tube has } \\
\text { white scale }\end{array}$ & no apparent change \\
\hline $\begin{array}{l}\text { SURF/ } \\
\text { DOH-3 }\end{array}$ & $10 R-J$ & yes & expanded & $\begin{array}{l}\text { strong petroleum distillate odor; wet, red-brown paste; sur- } \\
\text { face appears to have very small crystals; several patches } \\
\text { colored steel-blue are apparent }\end{array}$ & $\begin{array}{l}\text { all peaks appear unaltered ex- } \\
\text { cept for the growth of a peak } \\
\text { at } 220\end{array}$ \\
\hline
\end{tabular}


RUN TABLE NO, 22

\begin{tabular}{|c|c|c|c|c|c|}
\hline \multicolumn{5}{|c|}{$\begin{array}{l}\square \text { DRY (Type A) } \\
\square \text { HYDROTHERMAL - LON HATER (Type C) } \\
\square] \text { HYDROTHERMAL - HIGH WATER (TyPe D) }\end{array}$} & $\begin{array}{l}\text { TEMPERATURE: } \frac{400 \text { oC }}{30 \text { Days }} \\
\text { DURATION: } \frac{30}{4000} \text { PSi }\end{array}$ \\
\hline Specimen & Code & $\begin{array}{l}\text { Seal } \\
\text { Maintained } \\
\text { During Run }\end{array}$ & $\begin{array}{l}\text { Description of } \\
\text { Reaction Tubes }\end{array}$ & Optical Microscope Observations & $x$-ray Observations \\
\hline$P W-7 a$ & 10R-K & no & & & \\
\hline $76-68$ & IOR-L & yes & collapsed & $\begin{array}{l}\text { wet, compacted solid; inner surface of Au thoe and solid sur } \\
\text { face are coated with large, rectangular, colorless crystals; } \\
\text { surface of solid also has euhedrat equant crystals body colo } \\
\text { of solid light green spotted with black grains, large crystal } \\
\text { appears to be untaxial (-) with moderate relief and NC } 1.524\end{array}$ & 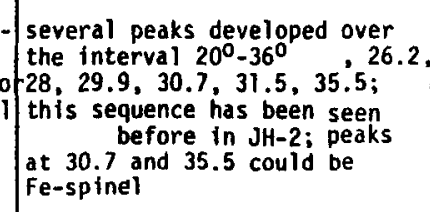 \\
\hline SPC-2 & IOR-H & yes & expanded & $\begin{array}{l}\text { wet compacted solid; surface has experienced gra in growth; } \\
\text { very obvious emerald green clusters of grain on gray back- } \\
\text { ground }\end{array}$ & $\begin{array}{l}\text { no apparent change; perhaps } \\
\text { sharp, better crystallization } \\
\text { if anything }\end{array}$ \\
\hline SURF & POR-N & yes & collapsed & $\begin{array}{l}\text { wet, loose, powder: color is dark brown with a few white } \\
\text { grains distributed in powder }\end{array}$ & no apparent change \\
\hline $\begin{array}{l}4105 S / \\
46-68 / \\
B C R-1\end{array}$ & hOR-0 & no & & & \\
\hline $\begin{array}{l}1105 s / \\
60 H-3 / \\
66-68\end{array}$ & PR-P & $\begin{array}{l}\text { no (?) } \\
\text { stuck to- } \\
\text { gether with } \\
\text { several } \\
\text { other tubes } \\
\text { p hole.was }\end{array}$ & rn into it when separated & $\begin{array}{l}\text { dry, compacted sol id; surface has many colorless, euhedral } \\
\text { crystals growing from it (looks like quartz) }\end{array}$ & \\
\hline
\end{tabular}


RUN TABLE NO, 23

hYorotherual - LON MATER (Type C)

$\square$ HYOROTHERMAL - HIGH MATER (TYPe D)

\begin{tabular}{|c|c|c|c|c|c|}
\hline Specimen & Code & $\begin{array}{l}\text { Seal } \\
\text { Maintained } \\
\text { During Run }\end{array}$ & $\begin{array}{l}\text { Description of } \\
\text { Reaction Tubes }\end{array}$ & Optical Microscope Observations & $x$-ray Observations \\
\hline $\begin{array}{l}\text { CsOH/ } \\
\text { Plag. } \\
\text { Dist } \mathrm{H}_{2} \mathrm{O}\end{array}$ & BES-1-A & yes & collapsed & $\begin{array}{l}\text { distinct pungent odor; light gray granular sulid with black } \\
\text { flakes distributed throughout }\end{array}$ & pollucite peaks \\
\hline $\begin{array}{l}\mathrm{CsOH} \\
\mathrm{NaOH} \\
\mathrm{Plag} \\
\mathrm{HGW}\end{array}$ & BES-1-B & no & collapsed & $\begin{array}{l}\text { distinct pungent odor; pasty, gray granular solid with black } \\
\text { flakes distributed throughout }\end{array}$ & \\
\hline $\begin{array}{l}\mathrm{CSOH} \\
\mathrm{MaOH} \\
\mathrm{Plag} \\
\mathrm{HGW}\end{array}$ & BES-1-C & no & expanded & dry, gray solid with few black flakes spread throughout & \\
\hline $\begin{array}{l}\text { Pollucite } \\
\text { Gel }\end{array}$ & BES-1-D & yes & collapsed & $\begin{array}{l}\text { aud fble pressure release upon opening tube; fine-grained } \\
\text { white powder }\end{array}$ & pollucite peaks \\
\hline $\begin{array}{l}\mathrm{CsOH} \\
\mathrm{NaOH} \\
\mathrm{Al}_{2} \mathrm{O}_{3} \\
\mathrm{SiO}_{2} \\
\text { Dist } \mathrm{H}_{2} \mathrm{O}\end{array}$ & BES-1-E & yes & collapsed & audible pressure release; wet, fine-grained white powder & pollucite peaks \\
\hline
\end{tabular}


RUN TABLE NO.

$\begin{array}{ll}\square \text { DRY (TYPe A) } & \text { TEMPERATURE: } \frac{425 \text { OC }}{30} \text { Days } \\ \square \text { HYROTHERMAL - LOW WATER (Type C) } & \text { DURATION: } \frac{\text { PRESSURE: }}{6000} \text { PSi }\end{array}$

\begin{tabular}{|c|c|c|c|c|c|}
\hline Specimen & Code & \begin{tabular}{|c} 
Seal \\
Maintained \\
During Run
\end{tabular} & $\begin{array}{l}\text { Description of } \\
\text { Reaction Tubes }\end{array}$ & Optical Microscope Observations & $x$-ray Coservations \\
\hline $\begin{array}{l}\mathrm{PW}-7 \mathrm{a} / \mathrm{I} \\
\mathrm{DOHH}-3\end{array}$ & 7-A & no & unchanged & wet, uniform, gray, granular solid; no obvious reaction & \\
\hline $\begin{array}{l}76-68 / \\
\mathrm{DDH}-3\end{array}$ & $7-8$ & yes & collapsed & $\begin{array}{l}\text { dry compacted sol id; two obvious particle sizes -- small } \\
\text { dark gray particles uniformally distributed through light } \\
\text { gray solid }\end{array}$ & $\begin{array}{l}600-2002 \theta \text { scan; } x \text {-ray diffrac- } \\
\text { tion pattern rema ined virtually } \\
\text { unchanged; only the basalt pat- } \\
\text { tern is recognizable; this is } \\
\text { superimposed upon an amorphous } \\
\text { background peaking at }-20^{\circ} 2 \theta\end{array}$ \\
\hline $\begin{array}{l}\mathrm{SPC}-2 / \\
\mathrm{DOH}-3\end{array}$ & $7-c$ & yes & collapsed & $\begin{array}{l}\text { dry, loosely compacted sol id; uniform gray body color; no } \\
\text { obvious reaction }\end{array}$ & 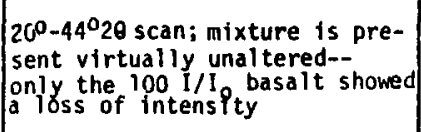 \\
\hline $\mathrm{ODH}-3$ & $7-0$ & yes & & & \\
\hline $\begin{array}{l}\text { SURF } / \\
\text { DOH-3 }\end{array}$ & 7-E & no & unchanged & wet, brown powder; uniform color throughout & $\begin{array}{l}26^{0}-44^{\circ} \text { scan; mixture of two } \\
\text { materials clearly visible } \\
\text { only apparent difference be- } \\
\text { tween before and after is a } \\
\text { relative sharpening of peaks }\end{array}$ \\
\hline
\end{tabular}


RUN TABLE NO. 25

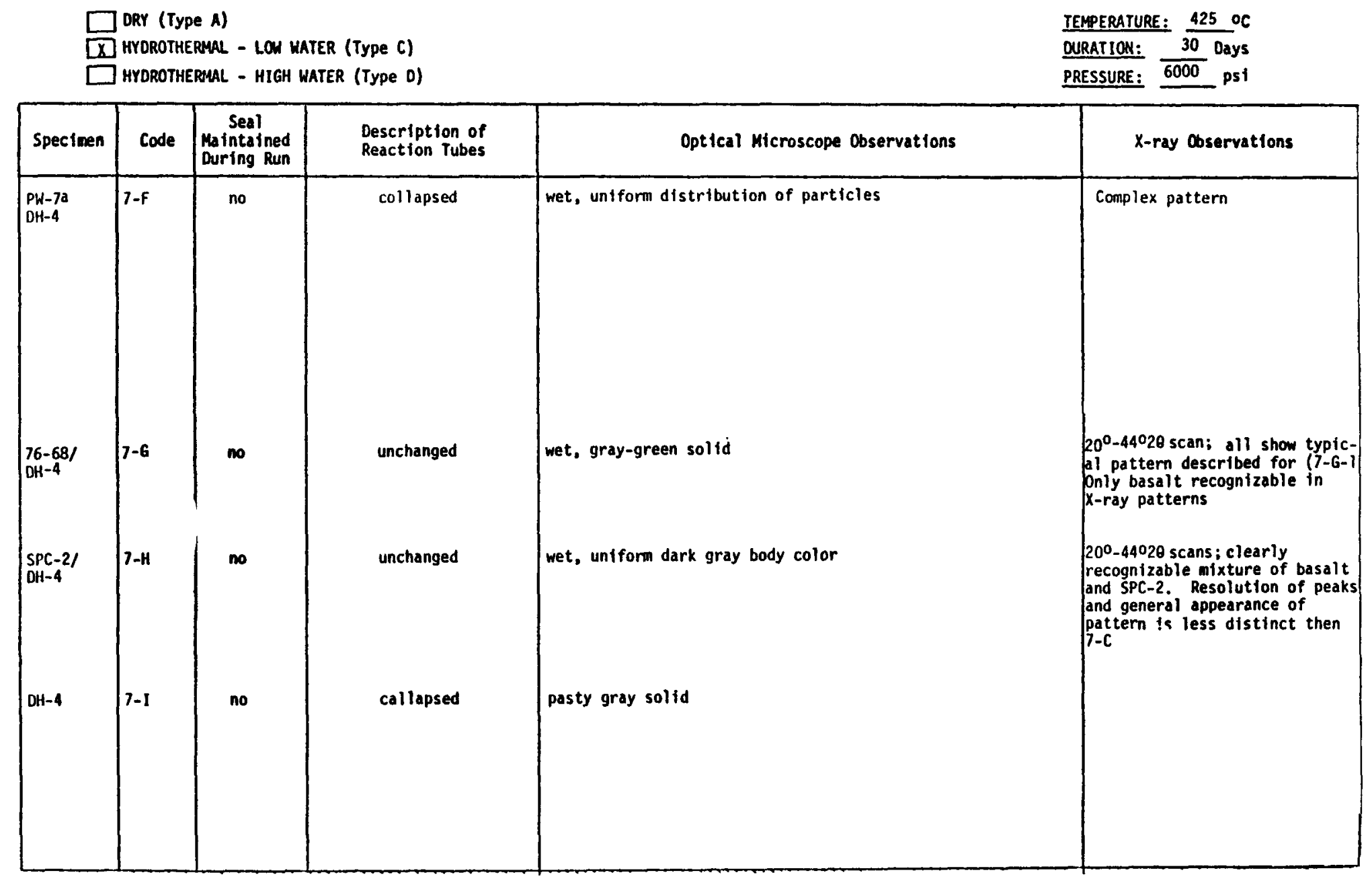


RUN TABLE NO, 26

\begin{tabular}{|c|c|c|c|c|c|}
\hline Specimen & Code & $\begin{array}{l}\text { Seal } \\
\text { Maintained } \\
\text { During Run }\end{array}$ & $\begin{array}{l}\text { Description of } \\
\text { Reaction Tubes }\end{array}$ & Optical Microscope Observations & $x$-ray observations \\
\hline $\begin{array}{l}\text { SURF/ } \\
\text { OH-4 }\end{array}$ & $7-\mathrm{J}$ & no & unchanged & wet, brown, solld & $\begin{array}{l}20^{0}-44^{\circ} \text { scan; although these } \\
\text { leaked their appearance is } \\
\text { only si shitly different than } \\
\text { (7-E); the low angle refiec- } \\
\text { tions are not as sharp }\end{array}$ \\
\hline 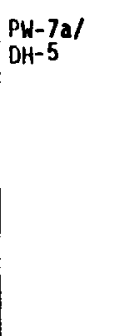 & $7-A-1$ & no & collapsed & wet, partially compacted, dark gray solid & 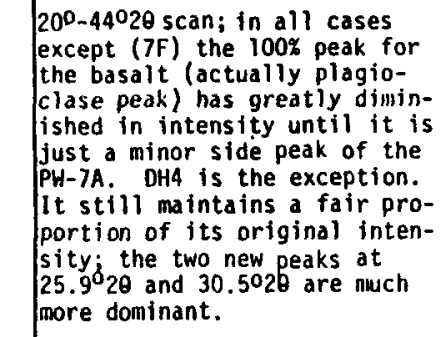 \\
\hline $\begin{array}{l}76-68 / \\
\mathrm{DH}-5\end{array}$ & 7-8-1 & no & & wet compacted solfd; gray-green mottling & $\begin{array}{l}20^{0}-44^{0} 20 \text { scan; all show typi- } \\
\text { cal pattern described for } \\
(7-6-1) \text {; only basalt recog- } \\
\text { nizable in } x \text {-ray patterns }\end{array}$ \\
\hline $\begin{array}{l}\text { SPC-2I } \\
\text { DII-5 }\end{array}$ & $7-C-1$ & no & collapsed & pasty, loose, uniform light gray solid & $\begin{array}{l}20^{0}-44^{\circ} 2 \theta \text { scans; clearly recog- } \\
\text { nizable mixture of basalt and } \\
\text { SPC-2; resolution of peaks and } \\
\text { general appearance of pattern } \\
\text { is less distinct than } 7-C\end{array}$ \\
\hline
\end{tabular}


RUN TABLE NO.

\begin{tabular}{|c|c|c|c|c|c|}
\hline \multicolumn{5}{|c|}{$\begin{array}{l}\square \text { DRY (TyPe A) } \\
\square \text { HYDROTHERMAL - LON KATER (Type C) } \\
\square \text { HYOROTHERMAL - HIGH HATER (Type O) }\end{array}$} & TEMPERATURE: $\begin{array}{r}425 \text { OC } \\
\text { OURATION: } \\
\text { ORESSURE: } \\
60000 \text { Days } \\
\text { Psi }\end{array}$ \\
\hline Specimen & Code & $\begin{array}{l}\text { Seal } \\
\text { Maintained } \\
\text { During Run }\end{array}$ & $\begin{array}{l}\text { Description of } \\
\text { Reaction Tubes }\end{array}$ & Opt Ical Microscope Observations & $x$-ray Coservations \\
\hline $\mathrm{OH}-5$ & $7-0-1$ & no & unchanged & $\begin{array}{l}\text { wet uniform dark gray solid; partially compacted with small } \\
\text { nodules in solid }\end{array}$ & \\
\hline $\begin{array}{l}\text { SURF/ } \\
\mathrm{DH}-5\end{array}$ & $7-E-1$ & no & unchanged & wet, partially compacted, brown solid & 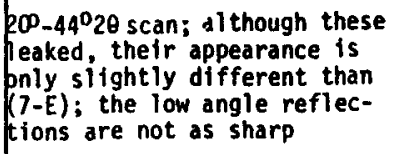 \\
\hline $\begin{array}{l}P H-7 a \\
U P B\end{array}$ & $\mid 7-8-1$ & no & unchanged & wet, uniform gray solid & 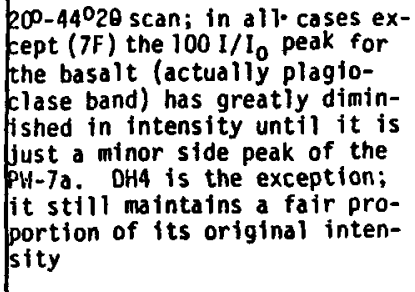 \\
\hline $\begin{array}{ll}76-68 / \\
\text { UPB }\end{array}$ & $7-6-1$ & yes & collapsed & $\begin{array}{l}\text { white crystall ine material at interface of tube and powder; } \\
\text { loase, dry, light gray powder }\end{array}$ & $\begin{array}{l}\text { 200-44020 scan; the x-ray dif- } \\
\text { fraction pattern appears to be } \\
\text { due entirely to basalt; in } \\
\text { tense reflections at } 20^{\circ} 20 \\
\text { are not present as interen They } \\
\text { flection in the starting mix- } \\
\text { ture }\end{array}$ \\
\hline
\end{tabular}


RUN TABLE NO.

\begin{tabular}{|c|c|c|c|c|c|}
\hline \multicolumn{5}{|c|}{$\begin{array}{l}\square \text { ORY (Type A) } \\
\square \text { HYDROTHERMAL - LOW WATER (Type C) } \\
\square \text { HYDROTHERMAL - HIGH WATER (Type D) }\end{array}$} & 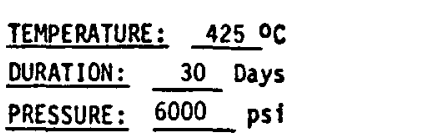 \\
\hline Specimen & Code & $\begin{array}{l}\text { Seal } \\
\text { Maintained } \\
\text { During Run }\end{array}$ & $\begin{array}{l}\text { Description of } \\
\text { Reaction Tubes }\end{array}$ & Optical Microscope Observations & $x$-ray Observations \\
\hline BCR-1 & $7-19$ & yes & collapsed & $\begin{array}{l}\text { dry corpacted solid; inhomogeneous - small green particles' } \\
\text { in gray porder }\end{array}$ & \\
\hline $\begin{array}{l}P \text { PN-7 al } \\
B C R-1\end{array}$ & $7-15$ & yes & collapsed & dry compacted solid; 30\% small euhedral crystals on solid ${ }^{\circ}$ & 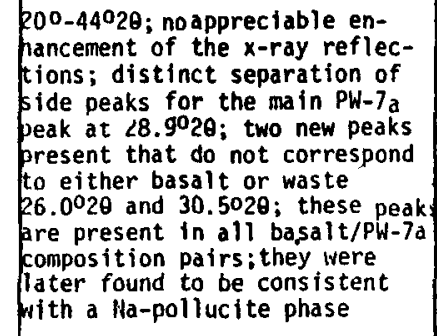 \\
\hline $\begin{array}{l}76-68 / \\
8 C R-1\end{array}$ & $7-16$ & no & collapsed & $\begin{array}{l}\text { wet, compacted, gray-green solid; gray groundmass with few } \\
\text { white grains }\end{array}$ & $\left|\begin{array}{l}200-44020 \text { scan; all show typical } \\
\text { pattern described for }(7-6-1) ; \\
\text { only basalt recognizable in } \\
\text { x-ray patterns }\end{array}\right|$ \\
\hline $\begin{array}{l}\text { SPC-2I } \\
\text { BCR-1 }\end{array}$ & $7-17$ & no & callapsed & pasty, compacted, gray powder & $\begin{array}{l}200^{-} 44020 \text { scan; virtually the } \\
\text { same } x \text {-ray pattern as }(7-c) \text {; } \\
\text { however, each individual re- } \\
\text { flection is more intense re- } \\
\text { vealing a much cleaner, sharper } \\
\text { pattern; the reflection attri- } \\
\text { butable to sPC-2 appear to } \\
\text { dominate in intensity }\end{array}$ \\
\hline
\end{tabular}


RUN TABLE NO.

$\square$ DRY (Type A)

$X$ HYDROTHERMAL - LON MATER (TyPe C)

$\square$ HYDROTHERMAL - HIGH WATER (TYPe D)

TEMPERATURE: 425 OC

DURATION: 30 Days

PRESSURE: 6000 psi

\begin{tabular}{|c|c|c|c|c|c|}
\hline Specimen & Code & $\begin{array}{l}\text { Seal } \\
\text { Maintained } \\
\text { During Run }\end{array}$ & $\begin{array}{l}\text { Description of } \\
\text { Reaction Tubes }\end{array}$ & Optical Microscope Observations & $x$-ray Observations \\
\hline $\begin{array}{l}\text { SURF/ } \\
\text { BCR-1 }\end{array}$ & $7-18$ & no & collapsed & $\begin{array}{l}\text { wet brown solid, euhedral, colorless; doubl, terminated } \\
\text { crystals in open end of tube }\end{array}$ & $\begin{array}{l}200-44^{\circ} \theta \text { scan; although these } \\
\text { leaked, their appearance is } \\
\text { only sightly different than } \\
\text { ( } 7-E \text { ); the low angle reflec- } \\
\text { tions are not as sharp }\end{array}$ \\
\hline $\begin{array}{l}\text { SPC-2/ } \\
\text { UPB }\end{array}$ & $7-H-1$ & yes & collapsed & dry, light gray, compacted solfd & $\begin{array}{l}200-44020 \text { scan; this pattern } \\
\text { is very much different than } \\
\text { the other four: the basalt } \\
\text { peaks conpletel dominate pat- } \\
\text { tern; they are typicaliy in- } \\
\text { tense with small halifwldth } \\
\text { (perhaps } 90 \% \text { basalt, 10\% SPC } \\
\text { instead of 50-50) }\end{array}$ \\
\hline $\begin{array}{l}\text { SURF/ } \\
\text { UPB }\end{array}$ & $7-1-1$ & no & & wet, uniform brown solid & \\
\hline UPB & $7-\mathrm{J}-1$ & no & collapsed & uniform, paste, dark gray solid & \\
\hline PH-7a & $7-2 \mid$ & no & unchanged & wet, gray colored solid with a few orange and green grains & \\
\hline $76-68$ & $7-22$ & no & collapsed & $\begin{array}{l}\text { pasty: mottled, gray-black granular solid; sample contains a } \\
\text { thin dark gray skin of very small particles where it was in } \\
\text { contact with the Pt tube; sample compacted in tube; dark } \\
\text { skin shows patches of black glassy material }\end{array}$ & \\
\hline
\end{tabular}


RUN TABLE NO,

$\square$ DRY (Type A)

$\square$ HYDROTHERMAL - LOW HATER (TYPe C)

$\square$ HYOROTHERUAL - HIGH WATER (TyPe D)

TEMPERATURE: 425 OC

DURATION: 30 Days

PRESSURE: 6000 PS

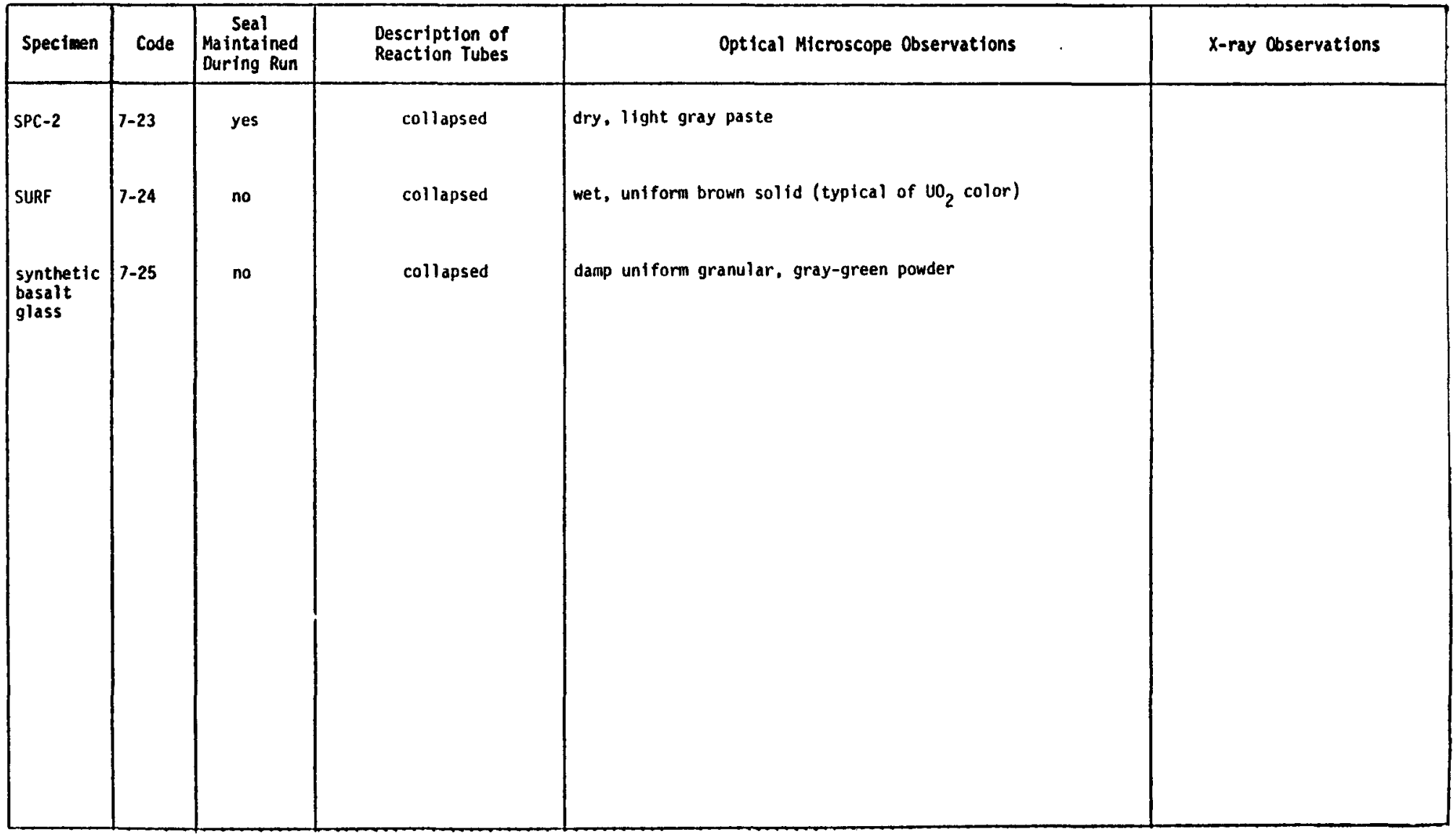




\section{BIBLIOGRAPHY}

A. A. Ballman and R. A. Laudise (1963). "Hydrothermal Growth," in the Art and Science of Growing Crystals, J. J. Gilman, Ed., John Wiley \& Sons, New York.

A. L. Boettcher and D. M. Kerrick (1971). "Temperature Calibration in Cold-Seal Pressure Vesse1s," in Research Techniques for High Pressure and Temperature, G. C. Ulmer, Springer-Verlag, New York.

D. S. Coombs, A. J. Ellis, W. S. Fyfe, and A. M. Taylor (1959). The Zeolite Facies, with Comments on the Interpretation of Hydrothermal Synthesis, Geochim. and Cosmochim. Acta, 17, 53-107.

R. A. Deju, M. W. Grutzeck, C. W. Myers, and P. A. Eddy, Environmental Factors Needed to Establish the Geotechnical Feasibility of Storing Radioactive Wastes in Columbia River Basalts, RHO-ST-8, Rockwell Hanford Operations, Richland, Washington (September 1977).

D. B. Hawkins and Rustum Roy (1963). Experimental Hydrothermal Studies on Rock Alteration and Clay Mineral Formation. Geochim. et Cosmochim. Acta, 27, $1047-1054$.

D. W. Hyndman (1972). Petrology of Igneous and Metamorphic Rocks, McGrawHill Book Company, New York.

G. H. Jenks (1977). Overview of OWI Waste Rock Interaction Studies, NWTS Conference on Waste-Rock Interactions, July 6-7, 1977, The Pennsylvania State University, Report Y/OWI/SUB-77/74268, pp. 5-17.

Y. B. Katayama (1976). Leaching of Irradiated LWR Fuel Pellets in Deionized and Typical Groundwater, BNWL-2057, Battelle Pacific Northwest Laboratories, Richland, Washington, $78 \mathrm{pp}$.

R. A. Laudise (1970). The Growth of Single Crystals, Prentice-Hal1, Englewood Cliffs, New Jersey.

G. J. McCarthy and M. T. Davidson (1975a). "Ceramic Nuclear Waste Forms; I. Crystal Chemistry and Phase Formation in Calcine," Am. Ceram. Soc. Bul1., 54, 782-786.

G. J. McCarthy, M. T. Davidson, D. E. Pfoertsch, C. A. Smith, S. A. Gallagher, and R. G. Johnston (1975b). "Oxide Ceramic Nuclear Waste Forms," Am. Ceram. Soc. Bu11., 54, 459. 
G. J. McCarthy (1977a). "High Level Waste Ceramics: Materials Considerations, Process Simulation and Product Characterization," Nucl. Technolog., 32, 92-105.

G. J. McCarthy (1977b). "Ceramics and Glass Ceramics as High Level Waste Forms," Ceramics and Glass Radioactive Waste Forms, D. W. Readey and C. R. Cooley, Eds., ERDA CONF-770102, pp. 83-99.

G. J. McCarthy (1977c), "Advanced Waste Forms Research and Development, Comprehensive Progress Report," The Pennsylvania State University, ERDA CO0-2510-12, 44 pp.

J. E. Mendel and J. L. McElroy (1972). Waste Solidification Program, Volume 10, Evaluation of Solidified Products, BNWL-1666, Battelle Pacific Northwest Laboratories, Richland, Washington.

J. E. Mende1, et al., (1977). Annual Report on the Characteristics of High Level Waste Glasses, BNWL-2252, Battelle Pacific Northwest Laboratories, Richland, Washington, $99 \mathrm{pp}$.

R. Roy (1956). "Aids in Hydrothermal Experimentation, II.," J. Am. Ceram. Soc., 39, 145-146.

R. Roy and 0. F. Tuttle (1956). "Investigations under Hydrothermal Conditions," in Physics and Chemistry of the Earth, Volume 1, Pergamon Press, New York, pp. 138-180.

TAD (1976). Alternatives for Managing Wastes from Reactors and PostFission Operations in the LWR Fuel Cycle, ERDA-76-43, U. S. Energy Research and Development Administration, Washington, D. C. (May 1976).

R. P. Turcotte and J. W. Wald (1977). Quarterly Progress Report, Waste Fixation Program, BNWL-2242, Battelle Pacific Northwest Laboratories, Richland, Washington, pp. 7-10.

J F. Winkler (1976). Petrogenes is of Metamorphic Rocks, Springer-Verlag, New York. 
DISTRIBUTION

Number of Copies

1

1

3

1

1

3

3

3

1

3

17
ATOMICS INTERNATIONAL

R. B. Paulson

ARGONNE NATIONAL LABORATORY

A. M. Friedman

BATTELLE-NORTHWEST

R. J. Serne

BROOKHAVEN NATIONAL LABORATORY

P. W. Levy

CORNING GLASS WORKS

M. G. Britton

LAWRENCE BERKELEY LABORATORY

J. A. Apps

LAWRENCE LIVERMORE LABORATORY

L. B. Ballou

A. G. Duba

L. D. Rams pott

LOS ALAMOS SCIENTIFIC LABORATORY

K. E. Apt

R. W. Charles

G. A. Cowan

NATIONAL ACADEMY OF SCIENCES

J. Pomeroy

OAK RIDGE NATIONAL LABORATORY

C. F. Baes, Jr.

J. 0. Blomeke

H. W. Godbee

THE PENNSYLVANIA STATE UNIVERSITY

G. J. McCarthy (10)

D. M. Roy 


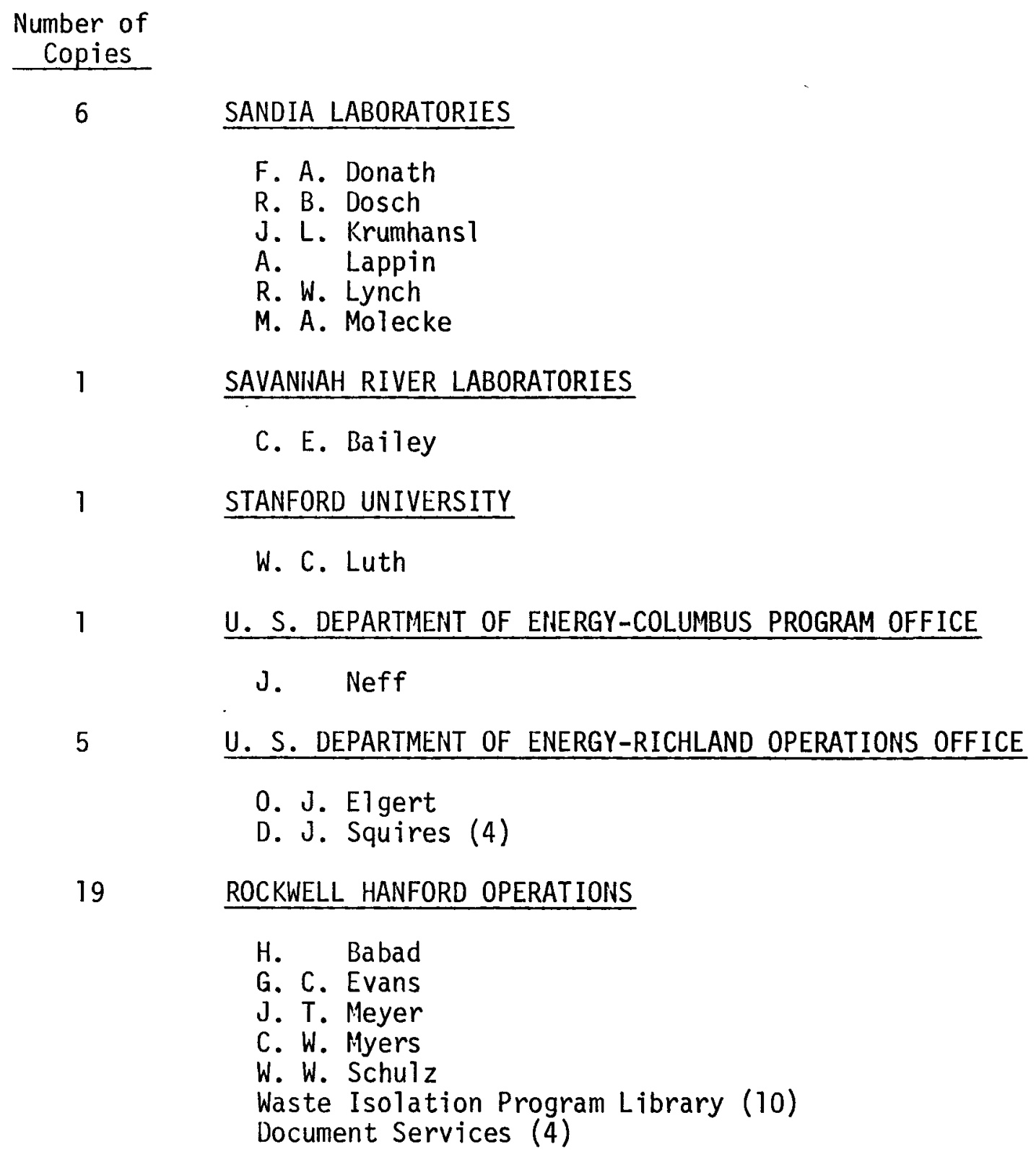

